UNIVERSIDADE DE SÃO PAULO

FACULDADE DE FILOSOFIA, LETRAS E CIÊNCIAS HUMANAS

DEPARTAMENTO DE FILOSOFIA

PROGRAMA DE PÓS-GRADUAÇÃO EM FILOSOFIA

CARLOS EDUARDO PEREIRA OLIVEIRA

\title{
A TEORIA CARTESIANA DA CRIAÇÃO
}

SÃO PAULO

2013 


\section{A TEORIA CARTESIANA DA CRIAÇÃO}

Tese apresentada ao Programa de PósGraduação em Filosofia do Departamento de Filosofia, Letras e Ciências Humanas da Universidade de São Paulo, para obtenção do título de Doutor em Filosofia sob a orientação do Prof. Dr. Homero Silveira Santiago.

SÃO PAULO 
À minha família. 


\section{AGRADECIMENTOS}

Aos meus pais, meus irmãos e meus sogros pelo apoio, incentivo e pela compreensão.

A Aline, minha esposa amiga, cuja serenidade, estímulo e cumplicidade foram indispensáveis à realização deste trabalho.

À Professora Laurence Renault por aceitar me acolher e orientar durante o estágio de doutorado na Universidade de Paris-Sorbonne. Suas contribuições enriqueceram e encorajaram o percurso do nosso trabalho.

À professora Marilena Chaui. Desde o mestrado, a senhora tanto tem contribuído para o aprimoramento das minhas pesquisas e me apontado novos caminhos a trilhar, no futuro, com a mesma generosidade, simplicidade e sabedoria.

Ao Professor Enéias Forlin cujos estudos sobre Descartes favoreceram a presente pesquisa. Obrigado pelo apoio e incentivo, pelas colaborações e amizade.

Ao Professor Homero Santiago por aceitar me orientar ao longo desses anos de estudo. Obrigado por acreditar em mim e pela amizade. Sua confiança, seu apoio, sua humana disposição em promover a minha formação encorajaram-me a perseverar, a transpor limites, superar desafios e amadurecer.

Finalmente, agradeço à CAPES - Coordenação de Aperfeiçoamento de Pessoal de Nível Superior - por financiar meu estágio junto à Universidade de Paris-Sorbonne. 


\section{RESUMO}

OLIVEIRA, Carlos Eduardo Pereira. A Teoria Cartesiana da Criação. 2013. $157 f$. Tese - Faculdade de Filosofia, Letras e Ciências Humanas. Departamento de Filosofia, Universidade de São Paulo, 2013.

Esta tese tem como objetivo expor a teoria cartesiana da criação, desenvolvida nas Meditações. Começando pela submissão dos fundamentos da tradição filosófica (o realismo e o idealismo) ao método da dúvida, a crítica cartesiana acabará por atingir a cosmologia cristã, consolidada por Tomás de Aquino sobre o realismo aristotélico, bem como as soluções idealistas favoráveis à existência de verdades, essências e naturezas eternas e incriadas. A partir daí, Descartes desenvolve uma concepção de criação cuja universalidade envolve a ideia de Deus, a coisa pensante, as coisas simples e universais e as coisas materiais. A universalidade da criação é uma exigência da ideia cartesiana de Deus como ser sumamente perfeito. Entendida como perfeição, a onipotência divina requer a dependência absoluta de todas as coisas em relação a Deus enquanto causa eficiente, isto é, causa criadora. Do contrário, há uma clara negação da onipotência e, consequentemente, da perfeição divina. Pretendemos ainda mostrar que a teoria cartesiana da criação é o fundamento da teoria da livre criação das verdades eternas, que alguns intérpretes consideram incompatível com o sistema cartesiano.

Palavras-chave: Realismo. Idealismo. Criação. Tomás de Aquino. Descartes. 
OLIVEIRA, Carlos Eduardo Pereira. The Cartesian Theory of Creation. 2013. $157 \mathrm{f}$. Thesis - Faculdade de Filosofia, Letras e Ciências Humanas. Departamento de Filosofia, Universidade de São Paulo, 2013.

This thesis aims to expose the Cartesian theory of creation, developed in Meditations. Submitting the foundations of the philosophical tradition, namely realism and idealism, to the methodical doubt, Cartesian criticism will eventually reaches out the Christian cosmology, consolidated by Thomas Aquinas on Aristotelian realism, as well as the favorable idealistic solutions to the existence of truths, essences and eternal and uncreated natures. From there, Descartes develops a conception of creation whose universality involves the idea of God, the thinking thing, the simple and universal things and the material things. The universality of creation is a requirement of the Cartesian idea of God as a supremely perfect being. Understood as perfection, divine omnipotence requires the absolute dependence of all things in relation to God while efficient cause, that is, creative cause. Otherwise, there is a clear denial of the omnipotence and consequently of the divine perfection. We also intend to show that the Cartesian theory of creation is the foundation of the theory of the creation of the eternal truths, that some interpreters consider incompatible with the Cartesian system.

Keywords: Realism. Idealism. Creation. Thomas Aquinas. Descartes. 


\section{SUMÁRIO}

INTRODUÇÃO

I. Contextualização da teoria cartesiana da criação 9

II. Contextualização histórica da teoria cartesiana da criação 11

III. A teoria cartesiana da criação no contexto do pensamento filosófico de

Descartes

PRIMEIRA PARTE: Suspeição dos fundamentos da tradição

CAPÍTULO PRIMEIRO: Apreciação dubitativa do realismo

1.1. Submissão do realismo ao método da dúvida 30

1.2. Invalidando os sentidos

1.3. Descoberta das coisas simples e universais e abandono do realismo 37

CAPÍTULO SEGUNDO: Apreciação dubitativa do idealismo

2.1. Considerações preliminares $\quad 42$

2.2. Buscando o significado das coisas simples e universais 45

2.2.1. Coisas simples e universais como essências 48

2.2.2. Sobre o estatuto de realidade das coisas simples e universais 5

2.3. A instauração da dúvida metafísica e a necessidade do fundamento causal 53

CAPÍTULO TERCEIRO: Teoria tomasiana da criação e objeções cartesianas

3.1. Explicação da sentença creatio ex nihilo e distinção radical entre Deus e os demais seres

3.1.1. A insuficiência ontológica como evidência da criação

3.1.2. Explicação tomasiana da criação

3.2. Reapreciação dos fundamentos realistas e abandono da cosmologia cristã realista 
4.1.1. Da descoberta da ideia à existência do Deus Criador 90

4.2. O criador universal e a universalidade do ato criador 93

$\begin{array}{ll}\text { 4.2.1. Deus causa eficiente da criação } & 93\end{array}$

4.2.2. Simplicidade divina e universalidade da criação 97

$\begin{array}{ll}\text { 4.2.3. Das coisas criadas por Deus } & 101\end{array}$

CAPÍTULO QUINTO: Demonstrações cartesianas da criação 105

5.1. Criação da coisa pensante 106

5.2. Criação das verdades eternas $\quad 114$

5.3. Existência e criação das coisas materiais

5.3.1. Existência das coisas materiais

5.3.2. Criação das coisas materiais $\quad 126$

CONCLUSÃOO 130

I. Consequências da universalidade da noção cartesiana de criação 130

II. A perfeição divina e a instituição do que é logicamente impossível 138

III. A incompreensibilidade divina e a negação da necessidade 142 


\section{INTRODUÇÃO}

\section{Contextualização da teoria cartesiana da criação}

Quando iniciamos este estudo, tínhamos apenas a hipótese da existência de uma teoria cartesiana da criação desenvolvida nas Meditações, capaz de fundamentar a teoria da livre criação das verdades eternas. À medida que a investigação se aprofundava, ficava claro para nós que a existência de uma teoria cartesiana da criação se inseria num dos grandes debates da história da filosofia, o debate cosmológico, de maneira que a teoria cartesiana da criação aparecia como uma nova cosmologia, por assim dizer moderna. Apresentaremos aqui os dois contextos em que essa teoria se situa, começando pelo mais abrangente, qual seja o do debate cosmológico, passando, em seguida, ao mais específico e interno ao cartesianismo, que a relaciona à teoria da livre criação das verdades eternas. Antes, porém, algumas palavras sobre a expressão cosmologia cartesiana.

Talvez a expressão cosmologia cartesiana soe estranha a alguns estudiosos em razão da física cartesiana. A existência de um possível problema me foi apresentada pela Professora Marilena Chaui, durante a qualificação. Gentilmente, ela me sugeriu observar essa questão. Em respeito e gratidão, procurei realizar uma pequena investigação a respeito. Os resultados, no entanto, não permitiram uma posição definitiva quanto à possibilidade de falarmos ou não em cosmologia cartesiana. Apesar disso, o problema pode vir a se tornar objeto de estudos posteriores.

Nosso percurso teve como ponto de partida o Dicionário Descartes, de J. Cottingham. Ao contrário do que eu esperava, encontrei aí o verbete cosmologia, cuja explicação enfatizava a ambição cartesiana em "fornecer uma explicação abrangente para as origens e estruturas do universo" cujo início teria sido dado no capítulo 6 do Le Monde. Quando exemplifica, Cottingham menciona os aspectos físicos do universo elucidados por Descartes. Ressalta ainda o Dicionário que a simplicidade com a qual Descartes descreve esse universo tecido no Le Monde aproxima-se em certa medida do “"princípio cosmológico perfeito', proposto por alguns astrônomos atuais" em seguida, Cottingham observa que "a abordagem cartesiana tem como efeito subordinar a cosmologia à física", pois segundo ele "não se invocam atos criadores

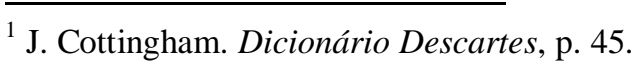


especiais ou propósitos divinos"2 . Infelizmente, é preciso discordar dessa interpretação, porque a primeira coisa a se afirmar no primeiro parágrafo do capítulo VI do Le Monde, antes de tratar do movimento, é que a matéria ali evocada foi criada por Deus. Ademais, se a subordinação da cosmologia à física é efeito da dispensa de atos criadores ou propósitos divinos, então devemos igualmente recusar essa subordinação ou invertê-la, fazendo com que a física seja subordinada à cosmologia. Primeiro, porque Descartes não nega que existam propósitos divinos na natureza. Ao contrário, ele nega que a razão possa conhecê-los, como se fosse partícipe dos desígnios de Deus: “jamais extrairemos quaisquer explicações acerca das coisas naturais a partir do fim que Deus ou a natureza se propôs ao fazê-las; porque não devemos ser arrogantes a ponto de nos julgarmos partícipes dos seus desígnios. Mas considerando-o causa eficiente de todas as coisas..."3. Depois, sendo o conceito de criação universal, atinge todas as coisas e as submete a Deus. Nesta submissão não podemos esquecer a tese da criação contínua de Descartes, que radicaliza a dependência de todo o criado em relação a Deus. Outra razão apresentada no Dicionário é a negação da visão geocêntrica. Ora, se o geocentrismo fosse um paradigma cosmológico, qualquer substituto poderia receber a mesma denominação. Dessa maneira, não nos parece convincente a tese de que Descartes subordina a cosmologia à física. No entanto, parece-me clara a existência dos dois domínios relacionados entre si. O que não posso afirmar é que se trata de uma relação de subordinação e, em caso afirmativo, se a subordinação não poderia ser da física à cosmologia. Com efeito, a análise do movimento no Le Monde é precedida pela exposição do fundamento, qual seja Deus criador da matéria. A tese da livre criação das verdades eternas estabelece a criação das leis físicas e matemáticas. Finalmente, a universalidade do conceito cartesiano de criação requer Deus como causa eficiente de todas as coisas que existem fora dele.

Deixando Cottingham, encontrei em Koyré uma tese interessante, mas que mais parece depor contra a física cartesiana ou negá-la, simplesmente por ser qualitativa, ou seja, desprovida de aplicações matemáticas: "O fato é bem conhecido. A física de Descartes, tal como exposta nos Princípios, não contém leis matemáticas exprimíveis. Ela é, de fato, tão pouco matemática como aquela de Aristóteles"4. Daniel Garber, por sua vez, no artigo Descartes, Matemática e o Mundo Físico, defende contra Koyré a

\footnotetext{
2 Ibidem, p. 46.

${ }^{3}$ Princípios, art. XXVIII.

${ }^{4}$ A. Koyré. Études Galiléennes, II, p. 46.
} 
existência de uma física cartesiana tecida em linguagem matemática. A primeira coisa a ser notada no início do artigo de Garber é o emprego dos termos cosmologia e física como sinônimos. À página 106 do artigo, ele fala da "física do Descartes maduro" e, mais abaixo, na mesma página, ele situa a força centrífuga no centro da cosmologia cartesiana. Já a partir da página 107, tomando como base uma carta a Mersenne a fim de defender a existência de uma física matemática em Descartes, Garber passa a empregar o termo física. Isso poderia nos levar a dois entendimentos da questão: primeiro, a alternância inicial entre física e cosmologia nos levaria a entendê-las como equivalentes; ou então, sendo a física cartesiana matemática, ela se distinguiria da cosmologia cartesiana, que é qualitativa. Neste caso, as Meditações, por exemplo, conteriam uma cosmologia, pois aí não há nenhuma descrição matemática; apenas descrevem a causa fundamental de todas as coisas que são ou podem ser. Se tal interpretação procede, a cosmologia cartesiana se inscreve no campo metafísico. Considerando a metáfora da árvore das ciências, a cosmologia forneceria os fundamentos, a partir dos quais a física poderia se desenvolver. Assim, a cosmologia precederia a física, o que aparece no Le Monde, pois a criação e a descrição da matéria antecedem o estudo do movimento 5 .

\section{Contextualização histórica da teoria cartesiana da criação}

A cosmologia teve origem na Grécia, precisamente na investigação racional dos primeiros filósofos em torno da physis, rompendo dessa maneira com as cosmogonias próprias das narrativas míticas ${ }^{6}$. Toda a cosmologia pagã ${ }^{7}$, de Tales a Porfírio, desenvolveu-se no intuito de consolidar o princípio cosmológico ex nihilo nihil fit, ou seja, que nada procede do nada. Em linhas gerais, o princípio sustenta a eternidade da matéria incriada ou da realidade material existente.

\footnotetext{
5 Quero mencionar alguns autores cujos trabalhos apontam para a existência de uma cosmologia cartesiana. Por exemplo, Raoul Ferrier, no artigo Aperçus Nouveaux sur la Cosmologie Cartésienne, defende uma cosmologia cartesiana mais abrangente e que não se limita à análise do espaço contínuo. Há também o estudo de Antonella Del Prete. Universo Infinito e Pluralità dei Mondi: Teorie Cosmologiche in Età Moderna. Segundo ela, a cosmologia cartesiana renova o debate com a ideia de um universo indefinido, comportando mundos indefinidos e homogênios, tal como são apresentados nos Princípios.

${ }^{6}$ Cf. Marilena Chaui. Introdução à História da Filosofia 1, p. 40-49.

${ }^{7}$ A expressão "filosofia pagã" foi utilizada pelos autores P. Aubenque, J. Bernhardt e F. Châtelet, como forma de homenagear Alexandre Kojève. Segundo os autores, a história da filosofia pagã compreende o período que vai do surgimento da Filosofia com Tales de Mileto até Porfírio, editor de Plotino, cujos textos pertencem ao século III de nossa era (Cf. P. Aubenque et alii. A Filosofia Pagã, v. 1, p. 15).
} 
Platão e seus seguidores estabeleceram a existência de dois planos do ser: o plano sensível, captado pelos sentidos, e o plano suprassensível e acessível apenas à mente, entendido como uma realidade inteligível e verdadeira causa da existência das coisas sensíveis. A realidade inteligível é constituída por Eide (Eidos, no singular) ou Ideias, termo que significa Formas e designa entidades ou substâncias que não podem ser confundidas com representações, pois não são pensamentos, mas aquilo que o pensamento pensa. Elas são realidades imateriais e incriadas em oposição à matéria, que, embora inferior, é igualmente incriada ${ }^{8}$.

Contra Platão Aristóteles negava a existência das Formas eternas e separadas. Porém, isso não significa que tenha rejeitado o princípio ex nihilo nihil fit ou ido contra a eternidade da matéria. Na verdade, é na cosmologia aristotélica que o princípio cosmológico se constituiu de modo mais bem elaborado. Isso porque Aristóteles conscientemente abordou o princípio, argumentando que sua desconsideração acarretaria o absurdo de derivar do não ser o mundo. Segundo ele, as realidades primeiras são as substâncias, que se encontram hierarquicamente organizadas. Mesmo quando se considera o universo como um todo, atesta-se que a substância é a sua parte primeira ${ }^{9}$.

Há, no entanto, três espécies de substâncias. Duas delas são sensíveis, sendo uma eterna e a outra perecível. A terceira é a substância imóvel, cuja existência é necessária e eterna ${ }^{10}$. A substância sensível eterna, embora possua alguma materialidade, não está sujeita ao movimento de geração e corrupção, mas apenas ao que comporta deslocamento espacial ${ }^{11}$. São, portanto, incorruptíveis e se encontram na parte superior da hierarquia. Todas as outras coisas dotadas de existência real são consideradas substâncias sensíveis perecíveis, dotadas da materialidade que comporta geração, corrupção e mudança.

\footnotetext{
${ }^{8}$ Cf. Platão. Timeu, 27d.-29d. Uma interessante discussão em torno do sentido de Eidos foi feita por Joseph Novak, também disponível na internet. Veja-se J. Novak. A Sense of Eidos. In EIDOS: Canadian Graduate Journal of Philosophy, vol. XIX, no. 2. January, 2005. As ideias são as essências das coisas, ou seja, o que faz com que cada coisa seja o que é. Platão também as denomina com o termo parádeigma, para indicá-las como paradigma ou modelo permanente de cada coisa. As Ideias são em si e por si. Isto significa, respectivamente, que elas não são forjadas pelos caprichos de qualquer sujeito nem estão submetidas ao devir. Verdadeiras causas do sensível, por natureza submetido à mudança, elas, ao contrário, permanecem imutáveis. Historicamente, denomina-se hiperurânio o conjunto das Ideias. Acessível apenas à mente, ele não pode ser tomado como um lugar físico, pois nada possui de sensível. Trata-se, na verdade, de um lugar que não é absolutamente um lugar (Cf. G. Reale e D. Antiseri. História da Filosofia I: Antiguidade e Idade Média, p.137-139).

${ }^{9}$ Cf. Aristóteles. Metafísica, 1069a10-29.

${ }^{10}$ Cf. Ibidem, 1071b1-10.

${ }^{11}$ Cf. Ibidem, 1069b1-30.
} 
O platonismo ressurge no século I a.C. Porém, até o advento da grande síntese de Plotino, será marcado por incertezas, oscilações e contradições, devido ao entrelaçamento variado do velho e do novo, razão pela qual é chamado de medioplatonismo, que abrangeu todo o período que vai do século I a.C. até o século II de nossa era. Atribui-se ao medioplatonismo a transformação das Ideias platônicas em pensamentos de Deus, ao identificart o mundo do Inteligível com a atividade e o conteúdo da inteligência suprema, algo fundamental para o pensamento cristão posterior, além da tentativa de elaborar uma síntese de Platão, a partir do Timeu, cuja relevância se fez notar tanto no neoplatonismo de Plotino como na Patrística, a primeira elaboração do pensamento cristão ${ }^{12}$.

No século III da nossa era, Plotino, o mais ilustre representante do neoplatonismo, escreve as Enéadas, uma das mais importantes obras da Filosofia Antiga, na qual se encontram suas lições filosóficas e sua cosmologia. Segundo ele, a realidade é constituída por entes. Todo ente é em virtude da unidade. Esta, por sua vez, pressupõe um princípio supremo como seu fundamento, que é o Primeiro e a razão de toda unidade superior. Toda a realidade abaixo do fundamento Primeiro provém dele, imediatamente ou por intermediários ${ }^{13}$. O Uno é também infinito e encontra-se acima do ser, da vida e do pensamento. Autossuficiente, ele é causa de si, e nele todas as coisas têm o fundamento da própria existência, é inclusive causa da matéria, que não é entendida por ele como um princípio contraposto ao Primeiro. Ela nasce do limite extremo da alma do universo, como etapa extrema do processo de emanação do Uno ${ }^{14}$.

Podemos afirmar, portanto, que de Tales a Plotino a filosofia pagã elaborou e consolidou uma cosmologia, tendo no princípio ex nihilo nihil fit seu fundamento cosmológico.

No período da helenização, sofrida inclusive pela Judeia desde o século IV a. C. e cuja influência se nota na tradução do Antigo Testamento para o grego e nos próprios textos do Novo Testamento escritos em grego koiné, nasceu Jesus Cristo. Após sua

\footnotetext{
${ }^{12}$ Cf. G. Reale e D. Antiseri. Op. cit. p. 328-329. Ver também Michel Erler \& Andreas Graeser, $O$ Medioplatonismo: Filosofia e Tradição. In Filósofos da Antiguidade 2.

${ }^{13}$ Cf. Plotino. Enéadas, V 4, 55-56.

${ }^{14}$ Veja-se A. Vázquez Ortiz. Las Tres Hipóstasis dentro del Pensamiento de Plotino: El Camino de la Materia, p. 1-8.
} 
morte, surge o cristianismo a partir de um acontecimento conhecido por Pentecostes, no qual, segundo o Novo Testamento, o Espírito Santo teria descido em forma de línguas de fogo sobre os apóstolos e discípulos reunidos em Jerusalém, fazendo-os romper o silêncio e propagar a verdade cristã, o Evangelho, ao mundo e suas nações ${ }^{15}$.

Curiosamente, o discurso de inauguração do cristianismo, realizado pelo apóstolo Pedro logo após o acontecimento de Pentecostes, não menciona a criação do mundo nem sua criação a partir de nada. O núcleo da nascente pregação cristã é o anúncio da ressurreição de Cristo, a exortação à conversão e inserção do homem em uma nova vida, através do batismo, pelo qual todos se tornariam filhos de Deus, o Pai. Por isso, o tema da criação em si é secundário ${ }^{16}$. Só a partir da propagação do cristianismo fora da Palestina, principalmente nas províncias romanas da Síria, Ásia Menor, Egito e na Itália, sobretudo Roma, que o tema adquirirá paulatinamente maior atenção. As cartas paulinas são exemplo disso. Nelas encontramos passagens afirmando a criação do mundo por Deus ${ }^{17}$, além da tese fundamental de que se servirá a tradição cristã posterior para provar a existência do Deus criador a partir do mundo existente ${ }^{18}$.

No âmbito do discurso sobre a criação, a questão da matéria foi um dos problemas que inseriram o cristianismo no debate com a elite intelectual greco-romana, para a qual o cristianismo era filosofia de bárbaros, ateia e politicamente subversiva ${ }^{19}$. Contra seus acusadores, os Padres da Igreja responderam com as Apologias, as primeiras tentativas de diálogo com o helenismo em defesa do cristianismo. Nelas, o tema da criação haveria de ser aprofundado e refinado, de modo a se constituir, primeiramente, como um discurso que expressa a identidade cristã, isto é, o cristão é aquele que professa a fé num único Deus criador de todas as coisas que existem e, depois, consolidar-se como autêntica cosmologia cristã, graças à acuidade filosófica de Tomás de Aquino. Assim, o desenvolvimento da cosmologia cristã passou por três momentos significativos.

O primeiro foi o da elaboração da doutrina cristã da criação. A partir da reflexão sobre o Timeu, e sua doutrina sobre a matéria e o demiurgo, os Padres da Igreja

\footnotetext{
${ }^{15}$ Cf. At. 2, 1-13. Citações bíblicas extraídas da Bíblia de Jerusalém.

${ }^{16}$ Cf. Juan L. Ruiz de la Peña. Teologia da Criação, p. 78.

${ }^{17} \mathrm{Cf} .1$ Cor 11,12 e 10,$26 ; 2$ Cor 4,6

18 "Porque o que se pode conhecer de Deus é manifesto entre eles, pois Deus lho revelou. Sua realidade invisível - seu eterno poder e sua divindade - tornou-se inteligível, desde a criação do mundo, através das criaturas" (Rm. 1, 19-20).

${ }^{19}$ Sobre a consideração do cristianismo como filosofia de bárbaros (barbaros philosophia), veja-se Guy G. Stroumsa. Barbarian Philosophy: The Religious Revolution of Early Christianity, especialmente o capítulo IV, p. 57-72.
} 
iniciaram a elaboração metafísica da doutrina da creatio ex nihilo. Comparando a filosofia platônica e as Escrituras, o apologeta Justino concluiu que Platão havia tomado a ideia de uma matéria originária e informe dos ensinamentos dos profetas ${ }^{20}$. Ele não hesita em assumir a existência prévia de uma matéria informe e incriada, sobre a qual o agir de Deus daria forma ao mundo, não diretamente, mas por meio do Logos, mediador da criação.

Taciano, discípulo de Justino, afirmava ser Deus o único sem princípio. Ele gera o Verbo, que produz a matéria necessária para criar. Embora admita a existência de uma matéria informe, Taciano nega que ela seja incriada e eterna, afirmando sua criação por Deus $^{21}$. Deus, incriado e imaterial, é causa produtora da matéria criada. Não causa imanente, pois Deus não se confunde com o mundo, mas transcendente e eterna. Justino e Taciano, embora divirjam quanto à origem da matéria, concordam em que ela precede as coisas criadas, seja ela eterna - conforme Justino deixa transparecer -, seja ela criada - segundo afirma Taciano.

A primeira afirmação patrística da creatio ex nihilo foi feita por Hermas, na obra $O$ Pastor $^{22}$, onde vincula a criação de todas as coisas a partir de nada ao Deus único. Segundo ele, o primeiro mandamento exige a fé no Deus Criador: "Primeiro de tudo, crê que existe um só Deus, que criou e trouxe todas as coisas do nada à existência"23. Embora lacônica, a afirmação contém a essência metafísica da doutrina da criação, e sua influência se fez sentir nos grandes expoentes de Alexandria.

Teófilo, opondo-se às teses helenistas, procurou mostrar que Platão e seus seguidores, concebendo a matéria coexistente com Deus caiam em contradição. Com efeito, fazer algo a partir de uma matéria preexistente é algo que qualquer artesão pode fazer, enquanto "o poder de Deus se manifesta no fato de que faz do nada tudo o que desejar" ${ }^{24}$. Mas o conhecimento de que as coisas foram criadas a partir de nada não é fruto de especulação filosófica, mas da Revelação. Teófilo rejeita a preexistência da matéria de duas maneiras. Em primeiro lugar, sua coexistência eterna com Deus, porque preserva a ideia de divinização da matéria e o panteísmo. Em segundo, sua anterioridade às coisas criadas, pois faz de Deus e do seu Logos uma espécie de demiurgo artesão. Deus faz tudo do nada, declara ele, e não a partir de uma matéria preexistente, mesmo

\footnotetext{
${ }^{20}$ Cf. Justino. Apologia, 1, 59.

${ }^{21}$ Cf. Taciano. Discurso aos Gregos, c. 12.

${ }^{22}$ Cf. Juan L. Ruiz de la Peña. Op. cit. p. 80.

${ }^{23}$ Hermas. O Pastor, Mandamento I, capítulo 26.

${ }^{24}$ M. J Rouet de Journel. Enchiridion Patristicum, p. 179.
} 
que considerada criada, razão pela qual se lhe atribuem a primeira elaboração taxativa da creatio ex nihilo ${ }^{25}$.

As objeções feitas por Teófilo à preexistência da matéria e sua consequência, que é transformar Deus em um demiurgo, serão aprofundadas por Clemente de Alexandria, para quem "Deus, o único verdadeiro Deus, é espiritual, e não sensível"26. Por isso, nenhuma matéria pode ser encontrada em Deus. E não pode porque "sempre a matéria tem necessidade de arte, enquanto Deus é sem necessidade"27. Se o mundo é obra de Deus, este tampouco poderia ser tomado como demiurgo que deu forma à matéria:

"Olhai o mundo inteiro, é sua obra; o céu, o sol, os anjos, são as obras de seus dedos. Quão grande é o poder de Deus! Basta apenas sua vontade para fazer o mundo; porque, sozinho, Deus o fez, porquanto somente ele é realmente Deus; pois unicamente seu querer criou e seu simples desejo é seguido de realização" ${ }^{, 28}$.

Se, por um lado, Clemente conseguiu estabelecer a existência de um Deus único e espiritual, no qual não pode ser encontrado qualquer indício de matéria, por outro, a concepção da preexistência da matéria e de sua criação por Deus segue sem uma solução satisfatória.

Levando em conta o persistente problema da matéria, Orígenes dirige-se agora não apenas aos platônicos e neoplatônicos, mas especificamente aos intelectuais cristãos, adeptos do gnosticismo:

"Surpreende-me que essas pessoas culpem aqueles que negam que Deus é o criador e a providência do universo, que elas os acusem de pensamentos impios, porque eles consideram que a grande obra do mundo permaneça sem artesão e sem nenhum provedor, enquanto elas mesmas incorrem em impiedade quando dizem que a matéria é incriada e coeterna ao Deus incriado"29.

\footnotetext{
${ }^{25}$ Cf. Salvador Verges. Dios y el Hombre: la Creación, p. 509.

${ }^{26}$ Clemént d'Alexandrie. Le Protreptique, IV 51, 5-6.

${ }^{27}$ Ibidem, 56, 5.

${ }^{28}$ Ibidem, 63, 1-3.

${ }^{29}$ Origène. Traité des Principes, II, 1, 4.
} 
Por que é possível admitir um Deus artesão, mas torna-se um absurdo admitir um Deus criador? Por que a matéria não pode ser criada? Há algo nela que impossibilite sua vinculação a Deus? Para os gnósticos, a matéria é intrinsecamente má e, por isso, não poderia ter sido produzida ou criada por Deus ${ }^{30}$. Afirmam ainda que se a matéria não existisse, Deus teria que fazê-la, para fazer ser o que antes nada era. Neste caso, a matéria fabricada por Deus ou haveria de ser superior, ou inferior ou de um gênero distinto da matéria considerada incriada, mas jamais seria a matéria deste mundo ${ }^{31}$. Em contrapartida, Orígenes salienta que tanto o ato de negar a Deus o poder de fazer as coisas do nada, quanto o de admitir a existência de um Deus criador e provedor do universo, mas que não cria a matéria são posições próprias dos que "ignoram o poder e a inteligência da natureza incriada" ${ }^{, 2}$. Ademais para receber as formas e as espécies deste mundo, é necessário que a matéria seja a mesma deste mundo, nem mais nem menos perfeita, tampouco de outro gênero ${ }^{33}$. A posição dos verdadeiros cristãos está alicerçada na autoridade das Escrituras. Citando o trecho do segundo livro de Macabeus, Orígenes vê nelas a razão definitiva para aceitar a criação de todas as coisas por Deus, a partir de nada, ou seja, sem precisar de uma matéria preexistente ${ }^{34}$.

O segundo momento, concretizado por Agostinho, foi o da constituição da criação como doutrina teológica. Inicialmente, Agostinho apresenta três modos distintos de uma realidade derivar de outra. O primeiro modo é por geração, por meio da qual uma substância deriva da própria substância geradora. $\mathrm{O}$ segundo modo é chamado fabricação, pelo qual o fabricado deriva de algo preexistente. $O$ terceiro modo pelo qual uma realidade deriva de outra é chamado criação ${ }^{35}$. Ora, para uma coisa ser considerada criada é necessário que o seja a partir do nada absoluto, isto é, nem da sustância divina nem de uma substância externa ${ }^{36}$. Tal ação compete apenas a Deus, cuja onipotência se expressa pelo fato de ter dado origem às coisas a partir do nada. Sendo assim, erram os que consideram o mundo como emanação de Deus - era o caso de Plotino -, pois isso equivaleria a dizer que o mundo possui a mesma substância divina, assim como erram os que afirmam, à semelhança de Platão, a existência de uma substância externa, a matéria informe, que teria sido modelada por Deus, em conformidade com os modelos

\footnotetext{
${ }^{30}$ Cf. Salvador Verges. Op. cit., p. 464-466. Ver também J. L. R. de La Peña. Op.cit., 81-83.

${ }^{31} \mathrm{Cf}$. Origène. Traité des Principes, II, 1, 4.

${ }^{32}$ Idem.

${ }^{33} \mathrm{Cf}$. Idem.

${ }^{34}$ Cf. 2 Mac. 7, 28.

35 Agostinho. Confissões XI, 7.

${ }^{36}$ Agostinho. Contra Felix, 2, 18.
} 
arquetípicos, as Ideias. Agostinho até admite a existência de uma matéria informe da qual o mundo fora criado, contanto que ela tenha sido igualmente criada por Deus ${ }^{37}$.

A matéria informe criada antes do mundo é atemporal, prescinde do tempo. Ela não é coeterna a Deus, mas nem por isso podemos considerá-la temporal, desprovida de forma e movimento ${ }^{38}$. Ora, se enquanto havia apenas a matéria informe, não havia tempo, então o tempo não é eterno, explica. Na verdade, é concriado com o mundo. Com efeito, o tempo está ligado ao movimento. Entretanto, não havia movimento antes do mundo. O movimento começa só com a criação do mundo ${ }^{39}$. Se Deus cria o mundo usando a matéria informe criada, a partir de que vêm as formas, que são as formas das criaturas desse mundo?

Na doutrina platônica, o demiurgo imprime forma à matéria contemplando os paradigmas absolutos ou Ideias existentes fora e acima de sua própria mente. Em Agostinho, em conformidade com a operação realizada pelo medioplatonismo, as ideias são transformadas em pensamentos de Deus. Nas Questões sobre as Ideias, afirma:

"Quem é que, sendo religioso e formado na verdadeira religião, mesmo que ainda não possa intuir as Ideias, ousaria negar a sua existência? Ao contrário, afirmará que tudo aquilo que existe, isto é, todas as coisas que têm seu gênero determinado por uma natureza própria para poderem existir, foram criadas por Deus. E por obra sua vive tudo aquilo que tem vida, toda a conservação do universo, a própria ordem com a qual as coisas mutáveis seguem o seu curso temporal em uma determinada medida, tudo isso está contido e é governado pelas leis do altíssimo. Ora, uma vez que isto está estabelecido e admitido, quem ousaria dizer que Deus criou todas as coisas irracionalmente? E como isso não pode ser dito nem crido, conclui-se então que toda coisa foi criada segundo a razão" ${ }^{40}$.

Com isso, fica claro que cada coisa existente é criada segundo uma razão própria e que as Ideias, às quais cada coisa corresponde, estão na mente do criador. Ora, como as Ideias das coisas criadas ou que ainda serão criadas encontram-se na mente divina, segue-se que tais Ideias são eternas e imutáveis e constituem as verdadeiras realidades.

\footnotetext{
37 "Criastes, portanto, Senhor, o mundo, da matéria informe. Criastes do nada este quase nada, donde, depois, fizestes as grandes coisas, que nós, os filhos dos homens, admiramos" (Agostinho, Confissões, XII, 8).

${ }^{38} \mathrm{Cf}$. Ibidem, XII, 12.

${ }^{39}$ Cf. Ibidem, XI, 12-14.

${ }^{40}$ Agostinho. Questôes sobre as Ideias, apud G. Reale e D. Antiseri, História da Filosofia I, p. 452.
} 
Assim sendo, tudo o que existe só existe porque participa dessas Ideias, seja qual for seu modo de ser. Resulta, pois, que a criação é fruto de uma vontade livre e de uma natureza inteligente, ou seja, que Deus decidiu criar as coisas que criou. Ele é, portanto, causa eficiente, livre e inteligente.

Finalmente, o momento da consolidação da doutrina da criação como cosmologia. Isso ocorre no século XIII, com Tomás de Aquino. Fundamentado no realismo aristotélico e guiado por seus princípios gnosiológicos, ele consolida como cosmologia a doutrina teológica da criação, cujo princípio cosmológico é a creatio ex nihilo. Apesar dos esforços empreendidos desde o início do cristianismo pelos pensadores cristãos, faltava à doutrina da criação uma justificação filosófica, ou seja, faltava-lhe demonstração racional. Não bastasse isso, a introdução de Aristóteles pelos filósofos árabes reacendia velhos temas como o da eternidade da matéria e o necessitarismo, exigindo ainda mais empenho por parte da intelectualidade cristã pela inteligibilidade da fé. Era, portanto, fundamental dar à doutrina da criação e à liberdade da vontade divina um caráter racional. Realizar esse projeto representaria para o cristianismo a definitiva conciliação entre fé e razão, entre teologia e filosofia, mas tendo a autoridade da fé e da teologia precedência à razão e à filosofia. O século XIII pode ser considerado aquele em que a consciência dessas dificuldades resultou no surgimento de importantes filósofos dispostos a concretizar o projeto de fundamentação filosófica da fé, sendo Tomás de Aquino o maior de seus representantes.

No âmbito cosmológico, Tomás tinha grande preocupação de encontrar uma maneira de fundamentar filosoficamente a doutrina cristã da creatio ex nihilo. Consciente do desafio, ele formulou a ousada tese de que "a existência da criação não é algo que se sustenta apenas pela fé, mas que também se demonstra pela razão" Coerente com o realismo aristotélico, a estratégia da argumentação tomasiana consistirá em partir das evidências fornecidas pela experiência sensível que nos remetem a uma causa suprema exterior e principal, cujo efeito mais sensível é o mundo.

Com a demonstração racional da criação, Tomás não apenas consolida em bases realistas a doutrina teológica como autêntica cosmologia cristã, tendo a creatio ex nihilo como seu princípio cosmológico, em oposição à cosmologia pagã e seu princípio ex nihilo nihil fit, como acredita haver refutado de uma só vez a existência de uma matéria

\footnotetext{
41 "Respondeo quod creationem esse, non tantum fides tenet, sed etiam ratio demonstrat". Tomás de Aquino, Scriptum super Sententiis, 2 Sent., d. 1, q. 1, a. 2. Todas as citações no original em latim da obra tomasiana foram extraídas da Opera Omniar Disponível em http://www.corpusthomisticum.org/iopera.html.
} 
caótica preexistente incriada e também o idealismo, que sustentava a existência de um mundo de Ideias existentes por si.

Portanto, o legado da tradição que chegou a Descartes não compreende apenas os dois grandes sistemas filosóficos, quais sejam idealismo e realismo; compreende também duas cosmologias antagônicas, cada uma com um princípio cosmológico próprio e autêntico: o princípio pagão ex nihilo nihil fit e o cristão creatio ex nihilo.

Uma visão clara de como essa herança foi recebida por Descartes nos é apresentada no trecho de abertura da Primeira Meditação:

"Já faz bastante tempo que eu me dei conta de que, desde os meus primeiros anos, eu havia recebido muitas opiniões falsas por verdadeiras, e que o que mais tarde fundei sobre princípios tão mal fundamentados, só poderia ser muito duvidoso e incerto; de modo que era necessário que eu tentasse seriamente, uma vez em minha vida, desfazer-me de todas as opiniões nas quais até então acreditara, e começar tudo de novo desde os fundamentos, se eu quisesse estabelecer qualquer coisa firme e constante nas ciências" ${ }^{, 42}$.

Para todo ser humano, a infância é aquele período em que tudo o que se pode saber como verdadeiro se recebe diretamente dos pais e mestres, cujas opiniões, por sua vez, alicerçam-se sobre a autoridade dos ensinamentos recebidos dos Antigos e que constituem as verdadeiras opiniões ${ }^{43}$. Transmiti-las equivalia a transmitir a verdade, convenientemente designada pelo nome de tradição.

Entre os inúmeros ensinamentos recebidos da tradição, estão os da filosofia. “Cultivada pelos mais elevados espíritos que viveram desde muitos séculos, nela não se encontra uma única coisa a respeito da qual não se haja discussão" ${ }^{\text {"44 }}$, revelando-se nisto quão pouco firmes eram seus alicerces, de modo a não se poder construir nada de sólido sobre eles ${ }^{45}$.

Era de se esperar que, devido à atitude passiva e infantil frente à tradição e ao mundo, Descartes viesse a fazer o mesmo que fizeram seus pais e mestres, a saber, transmitir o conjunto de verdades reunido pela tradição, fundando sobre os princípios

\footnotetext{
${ }^{42}$ Primeira Meditação, AT IX, 13.

43 "Fui instruído nas letras desde a infância, e por me haver convencido de que, por intermédio delas, poder-se-ia adquirir um conhecimento claro e seguro de tudo o que é útil à vida, sentia extraordinário desejo de aprendê-las" (Descartes. Discurso do Método, primeira parte, p. 37).

${ }^{44}$ Ibidem, p. 40-41.

${ }^{45}$ Cf. Ibidem.
} 
por ela estabelecidos as suas próprias opiniões. Em tempo, porém, percebe haver aceitado como verdadeiras incontáveis opiniões falsas, erguidas sobre princípios mal fundamentados e, "ao considerar quantas opiniões distintas, defendidas por homens eruditos, podem existir acerca de um mesmo assunto, sem que possa haver mais de uma que seja verdadeira, achava quase como falso tudo o que era apenas provável"46.

Atingindo a maturidade suficiente e saindo da submissão a seus preceptores, Descartes acredita ter superado definitivamente a passividade infantil. Então decide executar o propósito há muito concebido de destruir todos os fundamentos, provocando, finalmente, o inevitável desmoronamento de tudo o que estivesse erguido sobre eles ${ }^{47}$.

Ora, esse trecho de abertura da Primeira Meditação apresenta de chofre os motivos que dão início à investigação filosófica cartesiana, marcando decisivamente a história da filosofia dali em diante. A perplexidade cartesiana ante o caráter duvidoso das verdades transmitidas pela tradição dá início a um novo filosofar. Quando consideramos o legado cosmológico recebido por Descartes a partir desse trecho, inclinamo-nos a situar e ler as Meditações numa perspectiva cosmológica, que não apenas se opõe ao pensamento cosmológico anterior, mas que também tenta, nesse terreno, estabelecer fundamentos mais sólidos e mais seguros.

Para obtermos a certeza a respeito dessa perspectiva é necessário existir ao menos uma apreciação cartesiana de uma das cosmologias tradicionais. Ora, mais do que uma ligeira apreciação, encontramos nas Meditações uma teoria da criação, inserida no debate cosmológico com a tradição; mais que isso, a nosso ver é uma exigência interna ao sistema cartesiano, no sentido de servir de fundamento à teoria da livre criação das verdades eternas e assim garantir a unidade do pensamento filosófico de Descartes.

\section{A teoria cartesiana da criação no contexto do pensamento filosófico de Descartes}

\footnotetext{
${ }^{46}$ Descartes. Discurso do Método, p. 41.

47 "E acreditei com firmeza em que, por este meio, conseguiria conduzir minha vida muito melhor do que se a construísse apenas sobre princípios a respeito dos quais me deixara convencer em minha juventude, sem ter nunca analisado se eram verdadeiros". (Ibidem, p. 45).
} 
Este trabalho é também um prolongamento da pesquisa de mestrado ${ }^{48}$, na qual estudamos a polêmica teoria cartesiana da livre criação das verdades eternas e os problemas a ela inerentes. Nela, Descartes afirma que as verdades eternas foram criadas pelo Deus onipotente, cuja liberdade é absolutamente indiferente. Esse breve enunciado da tese acarreta várias dificuldades para a filosofia cartesiana, dentre as quais as mais graves apresentamos a seguir.

A primeira diz respeito à explicitação da noção de verdades eternas. Escrevendo a Mersenne, Descartes as entende como essências "tantum verae aut possibiles"49. Segundo Marion, as verdades eternas verae corresponderiam a verdades contingentes e existentes. Para nós, ao contrário, o termo designaria as verdades estabelecidas por Deus como verdades eternas necessárias e efetivas. Quanto às denominadas possibiles, como nota Marion, elas se referem aos dados especulativos cuja concepção não envolve contradição. Todavia, para ele as verdades eternas equivalem às verdades matemáticas ${ }^{50}$, enquanto para nós a noção cartesiana de verdades eternas, conforme atestam as cartas, abrange as verdades lógicas, matemáticas, físicas, metafísicas e morais.

Ademais, nas cartas, as verdades eternas são entendidas como essências, elas mesmas entendidas como coisa. Ocorre que nos Princípios Descartes afirma que as verdades eternas equivalem às noções comuns ou máximas do entendimento, que existem somente no pensamento, ao contrário da coisa ou afecção das coisas que existe fora do pensamento como alguma coisa existente. ${ }^{51}$ Os Princípios distinguem entre a coisa e a verdade eterna. As cartas, por sua vez, designando as verdades eternas como coisa, impedem-nos de compreendê-las no mesmo sentido dos Princípios.

Dada a abrangência da noção de coisa - envolvendo tanto aquilo que existe ou pode existir fora do intelecto como a realidade objetiva da ideia, isto é, a realidade do

\footnotetext{
${ }^{48}$ Veja-se Carlos E. P. Oliveira. Descartes: A Livre Criação das Verdades Eternas. Disponível em http://www.fflch.usp.br/df/site/posgraduacao/2008_mes/2008.Carlos_Oliveira.mes.pdf

49 A Mersenne, AT I, 149.

${ }^{50}$ Além de Marion (Cf. Sur la Theologie Blanche de Descartes, 28-34), assumem esta posição Fichant, pois afirma literalmente que "as verdades eternas são essencialmente matemáticas" (M. Fichant. Science et Métaphysique dans Descartes e Leibniz, p. 74) e, segundo nota Beyssade, também Gouhier ao tentar uma distinção entre exigências ontológicas - que são verdades incriadas - e as verdades eternas matemáticas criadas pela vontade de Deus (Cf. J-M Beyssade. Descartes au Fil de l'Ordre, p. 107-108). Trata-se, na verdade, do problema do alcance da teoria da livre criação das verdades eternas. Embora discorde em vários aspectos, a maioria dos comentadores reconhece que a validade absoluta dos princípios do entendimento fica numa situação delicada no contexto da teoria da livre criação e tenta uma solução satisfatória, procurando estabelecer a compatibilidade entre a "teoria das cartas" e o conjunto das obras canônicas de Descartes.

${ }^{51}$ Cf. Princípios, art. XLVIII e XLIX.
} 
conteúdo representado enquanto representado e a existência possível da essência -, pode-se dizer que a noção cartesiana de verdade eterna compreende os princípios do entendimento, as diversas classes de verdades e as essências, conforme mostra Gleizer $^{52}$.

Por outro lado, a equivalência operada nas cartas entre verdades eternas e essências impediria sua associação às noções comuns e às ideias, realidades que existem exclusivamente na mente, em favor de sua existência extramental. Seguindo esta argumentação, como as noções comuns ou máximas do entendimento não são propriamente coisa, conforme estabelecem os Princípios, já que jamais poderiam existir fora da mente, elas estariam fora do alcance da teoria da livre criação. Essa solução, no entanto, parece limitar a universalidade da ação criadora e a onipotência divina, admitindo determinadas coisas cuja existência não procederia de Deus, além de pôr em risco a perfeição divina, como se verá no presente trabalho.

A segunda dificuldade, talvez a raiz de todo o problema da teoria da livre criação das verdades eternas, consiste em afirmar a criação dessas verdades ${ }^{53}$. Ora, tal afirmação não apenas parece contraditória nela mesma como também contraria a posição da tradição teológico-filosófica cristã.

De acordo com essa tradição, criação é o ato pelo qual a vontade divina atualiza as essências presentes no intelecto divino, ou seja, é o ato pelo qual uma essência adquire existência. Tudo o que resulta da criação é radicalmente finito, contingente e exterior ao criador. Sabendo disso, como pode Descartes afirmar a criação das verdades eternas sem destruir-lhes o caráter necessário, ou seja, como podem as verdades eternas ser eternas e criadas ao mesmo tempo, sem que isso não seja contraditório nem comprometa a necessidade delas? Antes de saber de que maneira Descartes soluciona o problema da contradição, devemos investigar as razões que o levaram a propor uma teoria tão estranha.

A primeira razão diz respeito à simplicidade divina e, segundo investigamos, atinge a teoria tomasiana das faculdades divinas. De acordo com Tomás, o sentido absoluto de simplicidade divina consiste na identidade entre a essência e a existência em Deus $^{54}$, o que também demarca a radical distinção entre este e os demais seres. Descartes, por sua vez, observa que a simplicidade divina só será efetivamente absoluta

\footnotetext{
${ }^{52}$ Cf. M. A. Gleizer. Considerações acerca da Doutrina da Livre Criação das Verdades Eternas, p. 184.

${ }^{53}$ Cf. A Mersenne, AT I, 145 e AT I, 152.

${ }^{54}$ Cf. Tomás de Aquino. Suma Teológica I, q. 3, a. 3.
} 
se eliminar a distinção entre intelecto e vontade em Deus, mesmo que se trate apenas de uma distinção de razão. Em Tomás, o intelecto precede a vontade. Deus concebe as essências e sua vontade decide quais serão atualizadas, permanecendo as demais como possíveis no intelecto divino.

Descartes avalia que tal concepção estabelece uma prioridade ou submissão de uma das faculdades à outra, no caso, a submissão da vontade ao intelecto divino. Segundo ele, se a simplicidade divina é realmente absoluta, então querer, entender e criar em Deus devem ser uma e a mesma coisa, sem que um preceda o outro, nem mesmo logicamente ${ }^{55}$. Da concepção cartesiana de simplicidade decorre a absoluta indiferença da vontade divina, ou seja, que esta é totalmente arbitrária e não age orientada por qualquer razão de inteligibilidade nem tampouco em razão de qualquer finalidade $^{56}$. A indiferença divina repudia toda espécie de exigência, seja interna ou externa, metafísica, lógica ou moral que se imponha à ação criadora. Não há essências no intelecto divino precedendo e determinando sua vontade, nem mesmo como alternativas entre as quais Deus escolheria qual atualizar. Em suma, Deus poderia estabelecer como verdade tudo o que para nós é contraditório ${ }^{57}$.

A segunda razão se refere a uma certa concepção de que as verdades eternas possam existir independentemente de Deus, ou seja, sem que tenham sido criadas por ele, existindo como um outro eterno que Deus e impondo-se e ele. Aqui, Descartes se contrapõe a Suárez. Segundo o filósofo jesuíta, as verdades eternas não poderiam proceder de Deus, pois, se assim fosse, procederiam por intermédio de sua vontade. Ora, se procedem da vontade, diz ele, não procedem da necessidade. Assim sendo, Deus não as conheceria necessariamente nem essas verdades seriam necessariamente necessárias ${ }^{58}$.

Há algo muito curioso nesse debate com Suárez. Descartes não admite a existência de verdades eternas independentes de Deus, mas também não nega que elas sejam exteriores a Deus, como parece a Descartes decorrer da explicação suareziana. Se para Suárez proceder de Deus é vir a ser por meio da vontade, então as verdades eternas não provêm dele, o que leva Descartes a observar que essa postura introduz um outro

\footnotetext{
55 A Mesenne, 27 de maio de 1630. AT I, 152.

56 "Não há ordem nem lei, nem razão de bondade e de verdade que não dependa dele. De outra maneira, ele não teria sido totalmente indiferente a criar as coisas que ele criou" (Sextas Respostas, AT IX, 23).

${ }^{57}$ Cf. AT I, 152. A Arnauld, 29 de julho de 1648. AT V, 224. Sextas Respostas, AT IX, 235.

${ }^{58}$ Cf. F. Suárez. Disputationes Metaphysicae, Disputatio XXXI, s. 12, § 40.
} 
eterno que Deus, considerando-a uma posição blasfema ${ }^{59}$. Aparentemente Descartes concorda com Suárez em que as verdades eternas sejam exteriores a Deus, mas desde que elas dependam de Deus, isto é, sejam criadas ${ }^{60}$ por meio de uma causalidade eficiente $^{61}$.

Segundo Descartes, Deus é uma causa cujo poder ultrapassa os limites do nosso entendimento, ao passo que a necessidade das verdades eternas não excede o nosso conhecimento $^{62}$. Essa necessidade está na medida do nosso entendimento, ou seja, o intelecto finito não pode pensar a possibilidade de sua contradição. Sua necessidade constrange o entendimento humano ${ }^{63}$. Em relação a Deus, Descartes afirma que as verdades eternas são algo de inferior e sujeito à sua potência incompreensível ${ }^{64}$. Primeiro, são inferiores porque são criaturas. Além disso, sua criação indica que sua necessidade não se impõe a Deus, mas lhe é submissa. Diante disso, surge o problema: se a necessidade é uma exigência interna do pensamento, então, de um lado, as coisas poderiam ser completamente contraditórias e, do outro, o intelecto finito não conseguiria conhecê-las tais como são ${ }^{65}$.

Descartes, porém, jamais afirmou a impossibilidade de a razão humana conhecer verdadeiramente a realidade. As cartas não mencionam o Deus veraz. No entanto, afirmam claramente que as verdades eternas criadas gozam da mais inteira necessidade e que, uma vez estabelecidas, Deus não as muda ${ }^{66}$. A vontade imutável divina garante a imutabilidade dessas verdades, as quais Descartes admite compreender como imutáveis e eternas ${ }^{67}$. A incompreensível potência criadora não parece ser requerida para destituir as verdades eternas de sua eternidade e imutabilidade. Ao contrário, ela estabelece como incompreensível o ato pelo qual o criador produz as verdades eternas em sua inteira necessidade, algo deveras incompreensível e contraditório para o intelecto finito, acostumado a limitar a onipotência divina, presumindo que sua imaginação tem tanta

\footnotetext{
${ }^{59}$ Cf. A Mersenne, 6 de maio de 1630. AT I, 149.

${ }^{60} \mathrm{Cf}$. A Mersenne, 27 de maio de 1630. AT I, 151-152.

${ }^{61}$ Cf. Idem. Cf. Quartas Respostas, AT IX, 186.

${ }^{62}$ Cf. A Mersenne, 6 de maio de 1630. AT I, 150. Assim, mesmo que na noção das verdades eternas não se incluam os princípios ou máximas do entendimento, eles não escapam à onipotência divina, que tem o poder para estabelecer como verdadeiro o que para nós é contraditório.

${ }^{63}$ Cf. A Arnauld, 29 de julho de 1648. AT V, 224.

${ }^{64} \mathrm{Cf}$. A Mersenne, 6 de maio de 1630 . AT I, 150.

${ }^{65} \mathrm{H}$. Frankfurt desenvolve esse problema no artigo Descartes on the Creation of the Eternal Truths, p. 36-57.

${ }^{66}$ Cf. L'Entretien avec Burman, AT V, 166-167.

${ }^{67}$ Cf. A Mersenne, 15 de abril de 1630. AT I, 145-146.
} 
extensão quanto ela ${ }^{68}$. De acordo com Descartes, portanto, não podemos ter a temeridade de achar que o nosso pensamento é capaz de impor qualquer necessidade às coisas $^{69}$. Muito pelo contrário, “é porque Deus assim o quis e assim as dispôs, elas são imutáveis e eternas"

A partir do exposto, esperamos ter realizado um breve panorama dos problemas da polêmica teoria da livre criação das verdades eternas, estudada em nosso mestrado com o intuito de mostrar sua compatibilidade com o sistema cartesiano. Na ocasião, concluímos nossa dissertação sugerindo a hipótese de que talvez seja um equívoco admitir que a noção cartesiana de criação mantém o mesmo significado da noção teológico-filosófica cristã, e que talvez fosse essa a razão pela qual alguns estudiosos do cartesianismo sustentam que Descartes, apercebendo-se dos riscos de submeter as verdades eternas à ação criadora, tenha decidido abandoná-la, evitando, dessa maneira, a ulterior destruição do seu sistema. Mas teria sido a teoria da livre criação das verdades eternas concebida e elaborada à margem do próprio sistema cartesiano ou talvez tivesse sido abandonada? $?^{71}$

A fim de eliminar os argumentos da marginalidade e ulterior abandono da teoria da livre criação das verdades eternas ${ }^{72}$, seria preciso encontrar nas chamadas obras canônicas de Descartes o seu fundamento. Felizmente, nossas buscas nos permitiram encontrar o conceito de criação nas Meditações, o qual, por sua vez, nos permitiu descobrir uma teoria cartesiana da criação, cujo conceito de criação, ultrapassando o limite imposto pelo conceito original tecido pela tradição teológico-filosófica, dá fundamento à teoria da livre criação das verdades eternas. Ademais, a teoria cartesiana

\footnotetext{
${ }^{68}$ Cf. A Mersenne, 15 de abril de 1630 . AT I, 146.

${ }^{69} \mathrm{Cf}$. Quinta Meditação. AT IX, 53

${ }^{70}$ Quintas Respostas, AT VII, 380.

${ }^{71}$ É o caso, por exemplo, da interpretação de Frankfurt, para quem a teoria cartesiana parece instaurar uma dúvida ainda mais profunda, de modo a representar uma ameaça ao sistema cartesiano, uma vez que essa tese poderia questionar a verdade e a validade em si dos princípios lógicos (Cf. H. Frankfurt. Op. cit., p. 50-53); ou ainda Koyré, que, crendo ser um disparate a teoria da livre criação, prefere supô-la abandonada por Descartes, sob o risco de destruir o seu sistema racionalista (Cf. A. Koyré. Essai sur l'Idée de Dieu, pp. 14-24).

${ }^{72}$ Não obstante o esforço empreendido e fundamentado tanto nos textos cartesianos quanto nos estudos dos intérpretes que, embora reconhecendo a extrema dificuldade da teoria da livre criação das verdades eternas, defendem sua compatibilidade e rejeitam sua exclusão do pensamento cartesiano, não há como negar o fato de que ela só foi explicitamente tematizada na Correspondência, nas Quintas e Sextas Respostas e nas Conversações com Burman. Porém, não ter sido tratada explicitamente não significa que não esteja subjacente ao pensamento filosófico cartesiano. Ademais, ainda que a teoria tenha sido escrita de forma marginal, isso não autoriza nenhum de nós a marginaliza-la da filosofia de Descartes. Outro argumento utilizado pelos defensores da incompatibilidade entre a teoria da livre criação e o pensamento cartesiano se refere ao fato de que ela foi desenvolvida entre os anos de 1630 e 1649. Isso os leva a concluir que Descartes a teria abandonado. Teria sido mesmo assim? E se suas teses fundamentais estiverem presentes, por exemplo, nas Meditações?
} 
da criação não parece ser fruto de uma mera vontade de fazer frente à tradição. $\mathrm{Na}$ verdade, ela se revela necessária ao sistema cartesiano. Assim como a negação da criação das verdades eternas compromete a onipotência divina na teoria da livre criação das verdades eternas, do mesmo modo a tese da universalidade da ação criadora exposta nas Meditações é imprescindível à noção de perfeição divina.

\section{$* * *$}

Para concluir, algumas palavras sobre a disposição da presente pesquisa. Nossa primeira intenção era dispô-la numa ordem cronológica. Como a teoria cartesiana se opõe à cosmologia cristã consolidada como tal por Tomás de Aquino, pensamos em começar apresentando a teoria tomasiana e, em seguida, a teoria cartesiana. Porém, preferimos uma exposição considerando a ordem da argumentação cartesiana. O debate cosmológico cartesiano com a teoria vigente é iniciado com a apresentação, na Primeira Meditação, das razões de duvidar, onde encontramos os motivos pelos quais Descartes deverá elaborar sua teoria da criação, a saber, a suspeita em relação aos fundamentos da tradição filosófica, quais sejam o realismo e o idealismo. Como o próprio Descartes assegurará, os ataques aos fundamentos acarretam o desmoronamento do que estiver sido construído sobre eles. Ora, a cosmologia cristã foi alicerçada por Tomás sobre os pilares do realismo aristotélico. Assim, visando demonstrar efetivamente a incidência da suspeita cartesiana sobre a cosmologia cristã, a exposição da teoria tomasiana da criação virá depois da apreciação dubitativa dos fundamentos da tradição.

Só então cuidaremos de expor propriamente a teoria cartesiana da criação. $\mathrm{O}$ nosso trabalho pretende tratar da criação tal como é indicada por Descartes. Criação é o ato pelo qual Deus causa as coisas exteriores, pelas quais entende a ideia do Deus criador, a coisa pensante, as coisas eternas e imutáveis e a coisa extensa. Em razão disso, não abordaremos no presente trabalho a noção de causa sui cartesiana, pois a causalidade criadora se refere às coisas distintas de Deus. Dessa maneira, o modo pelo qual Deus é causa de si não se identifica ao modo pelo qual ele causa as demais coisas. Finalmente, procuraremos mostrar a necessidade da causalidade criadora universal ao entendimento da perfeição divina. 


\section{PRIMEIRA PARTE \\ SUSPEIÇÃO DOS FUNDAMENTOS \\ DA TRADIÇÃO}


CAPÍTULO PRIMEIRO

APRECIAÇÃO DUBITATIVA DO

REALISMO 


\subsection{Submissão do realismo ao método da dúvida}

Nossa investigação começa levantando as razões que levaram Descartes a propor sua teoria da criação.

Segundo a proposta da Primeira Meditação, é preciso, em primeiro lugar, verificar a consistência dos fundamentos, a fim de certificar a solidez dos edifícios sobre eles alicerçados. Em vista disso, o filósofo submete à apreciação dubitativa os dois sistemas fundamentais da tradição filosófica, o idealismo e o realismo, dispostos não segundo a ordem histórica do seu surgimento, mas numa ordem platônica, em que se começa pela análise da realidade sensível em direção à realidade inteligível, de sorte que a análise do realismo precede a do idealismo.

A apreciação cartesiana do realismo tem início na seguinte passagem, onde submete à análise dubitativa o seu fundamento:

"Tudo o que eu admiti (admisi) até o presente como o mais verdadeiro e seguro, eu aceitei (accepi) dos sentidos ou através dos sentidos: ora, algumas vezes experimentei que esses sentidos eram enganadores, e a prudência recomenda jamais se fiar inteiramente nos que uma vez nos enganaram"73.

O fundamento do realismo é composto pelos seguintes elementos. Primeiro, o fundamento real, isto é, a existência indubitável da realidade exterior sensível. Depois, que essa realidade sensível exterior é captada pelos sentidos. Donde a tese de que todo nosso conhecimento provém dos sentidos, embora não provenha da mesma maneira, como nota Descartes. Num primeiro caso, proviria diretamente dos sentidos. Isso quer dizer que existem coisas sensíveis, eu as vejo, as sinto, enfim, as percebo; elas são reais. Que os sentidos as percebem é algo de que não se pode sensatamente duvidar, pois sua existência lhes é dada independente da vontade humana; as coisas afetam os sentidos e isso é suficiente para aceitar como verdade a existência de uma realidade fora de nós. Essa tese, no entanto, corresponderia a uma postura infantil ou ingênua, aceitando que as coisas são como nos aparecem. Ademais, os sentidos captam o particular e nesse particular há algo de mutável, de falso, razão pela qual não poderiam nos fornecer

\footnotetext{
${ }^{73}$ Meditatio Prima, AT VII, 18. A apreciação dubitativa do realismo começa nesse trecho citado, quando Descartes parafraseia o princípio realista, e se encerra com a descoberta das coisas simples e universais, a partir da qual terá início a apreciação dubitativa do idealismo.
} 
diretamente um conhecimento verdadeiro e necessário - tese, aliás, da qual Descartes partilha. Por isso, o realismo filosófico aristotélico-tomista transformava os sentidos em instrumentos, com os quais o intelecto extrai o universal num processo conhecido por abstractio (abstração) $)^{74}$.

Segundo a teoria da abstractio, a realidade material existente, composta de coisas sensíveis, deixa suas impressões em nossos sentidos. A imaginação, por sua vez, age sobre os dados por eles fornecidos, dando origem às espécies sensíveis, também chamadas imagens ou fantasmas. A espécie sensível nada mais é que a representação sensível de um objeto, ou ainda uma representação imaterial de um objeto material ${ }^{75}$. O intelecto, por sua vez, atuando sobre essas espécies, abstrai delas a quidditas (quididade), isto é, a essência universal, também chamada espécie inteligível, formando finalmente um conhecimento verdadeiro ${ }^{76}$.

A existência da realidade material é algo indubitável e pressuposto necessário a todo conhecimento. Esse processo, embora rejeite admitir que o conhecimento provenha diretamente dos sentidos, jamais previu eliminá-los. A correção estabeleceu sua instrumentalização, preservando, no entanto, a realidade sensível como fonte originária de todo conhecimento, conforme estabelecido pela tese realista de que nada há no intelecto que não tenha passado pelos sentidos, cabendo ao intelecto apenas abstrair a espécie inteligível, que lhe é própria, da espécie sensível, sem nada lhe acrescentar ou retirar.

Descartes, no entanto, observa que o problema fundamental não reside no modo pelo qual se dá a apreensão do conhecimento, ou seja, se direta ou mediante os sentidos. Problemático é o fundamento realista mesmo, ou seja, que todo conhecimento tenha origem nos sentidos, pois estes algumas vezes nos enganam e, sendo assim, deve-se duvidar deles, a menos que sejam capazes de resistir ao método da dúvida, cuja aplicação Descartes realiza percorrendo o mesmo caminho traçado na abstractio: a realidade afeta os sentidos, por meio dos quais a imaginação produz as espécies sensíveis, sobre as quais o intelecto age para produzir as espécies inteligíveis.

Ora, se tudo o que é verdadeiro provém dos sentidos, direta ou mediatamente, então é verdade que eles não enganam. Não obstante, constatamos que algumas vezes eles nos enganaram e, de acordo com Descartes, isso é motivo suficiente para rejeitá-los

\footnotetext{
${ }^{74}$ Uma exposição detalhada da teoria tomasiana da abstractio encontra-se na Suma Teológica I, q. 78-79 e 84-89.

${ }^{75}$ Cf. Tomás de Aquino. Suma Teológica I, q. 78, a. 4.

${ }^{76}$ Cf. Ibidem, q. 79, a. 2-5.
} 
e doravante jamais voltar a se fiar neles. Entretanto, não seria uma generalização indevida concluir que os sentidos nos enganam sempre, somente porque algumas vezes nos enganaram?

Para o realismo, o fato de os sentidos enganarem algumas vezes não nos autorizaria a rejeitá-los completamente, porque, na maioria das vezes, eles não enganam. Atento à argumentação realista, Descartes prossegue, concedendo que, nas poucas vezes em que enganam, o engano tenha acontecido devido, primeiro, ao objeto ser pouco sensível e, segundo, à sua distância.

"Se bem que os sentidos às vezes nos enganem no que diz respeito às coisas pouco sensíveis e muito distantes, encontramos talvez muitas outras, das quais não se pode sensatamente duvidar, apesar de as conhecermos por meio deles" $" 77$.

Um objeto pouco sensível é por si só inadequado aos sentidos, por não possuir sensibilidade suficiente. Depois, um objeto muito distante comprometeria igualmente a percepção sensível. Com efeito, em razão da distância mesma, a experiência sensível é prejudicada, pois o objeto não fica suficientemente perceptível. Portanto, exige-se que o objeto seja inteiramente sensível e tenha total proximidade. Satisfeitas essas condições, os sentidos garantem uma percepção inequívoca do seu objeto. Aparentemente de acordo, Descartes até enumera algumas coisas tão próximas e sensíveis que seria insensato duvidar de que são conhecidas através dos sentidos: estar em um lugar físico, cercado de objetos com os quais seu corpo e suas mãos interagem. Em condições tão privilegiadas como estas, só mesmo sob efeito da loucura para se ter uma percepção não correspondente à realidade:

"Exceto, talvez, que eu me compare a esses dementes, cujo cérebro está de tal maneira perturbado e ofuscado pelos negros vapores da bile que amiúde garantem que são reis, enquanto são bastante pobres; que estão trajados de ouro e púrpura, enquanto estão totalmente nus; ou imaginam ser vasos ou possuir um corpo de vidro. São loucos e eu não seria menos excêntrico se me pautasse por seus exemplos" $"$.

\footnotetext{
${ }^{77}$ Primeira Meditação. AT IX, 14.

${ }^{78}$ Idem.
} 
Além disso, assim como se exige dos objetos satisfazerem as condições de completa sensibilidade e total proximidade, exige-se que o sujeito esteja em condições normais para não comprometer a percepção sensível, ou seja, que ele se encontre no mais perfeito funcionamento de sua capacidade mental, isto é, sem o menor defeito no seu bom senso. Existindo tais condições, tanto para o objeto quanto para o sujeito, os sentidos têm, portanto, total autoridade para fornecer, do modo mais indubitável e seguro, o conhecimento verdadeiro, universal e necessário.

\subsection{Invalidando os sentidos}

Preservando todas as condições até aqui exigidas, o argumento do sonho as submeterá ao método da dúvida, a fim de verificar até onde os sentidos lhe resistirão. Antes, porém, da introdução do argumento, Descartes faz algumas observações.

É preciso considerar o ato de dormir e sonhar como hábitos normais do homem. Tal observação atenta para as condições normais nas quais deve estar o sujeito, isto é, o sonho, por mais extravagante que seja, a ponto de se assemelhar às coisas representadas pelos dementes despertos, nem por isso significa um mau funcionamento da sensação do sujeito ou defeito no seu bom senso. A extravagância onírica ou sua discrepância com a realidade é indício suficiente de que é sonho e que, portanto, a sensação não me engana. O sonho extravagante, porém, é uma situação atípica ${ }^{79}$.

Mas seria possível a sensação perceber nitidamente a distinção entre vigília e sonho? Não seria, por exemplo, apenas o hábito aliado a certas condições exteriores percebidas pelos sentidos - como o costume de dormir à noite, quando temos a sensação de sonolência - o princípio da certeza de que se distingue de modo inconfundível a realidade do sonho $?^{80}$ Para saber se a sensação, no seu perfeito funcionamento, é capaz de distinguir a vigília do sono e garantir que aquilo que percebe é efetivamente a realidade e não pura ilusão, Descartes evoca outra situação mais típica e mais provável:

\footnotetext{
79 Por exemplo, em alguns sonhos extravagantes, a fisionomia de uma pessoa pode repentinamente assumir a de outra. Ora, como tal coisa é impossível na realidade, logo se percebe muito claramente que se trata de um sonho.

80 "Contudo, devo aqui ponderar que sou homem, e, consequentemente, que tenho o hábito de dormir e de representar, em meus sonhos, as mesmas coisas, ou algumas vezes menos prováveis, que esses dementes despertos. Quantas vezes me aconteceu sonhar, durante a noite, que me encontrava neste lugar, vestido e próximo do fogo, apesar de me achar totalmente nu em minha cama?". Primeira Meditação. AT IX, 1415.
} 
"Afigura-se-me agora que não é com olhos adormecidos que olho para este papel; que esta cabeça que eu movo não se encontra adormecida; que é com intento deliberado que estendo esta mão e que a sinto: o que sucede no sono não parece ser tão claro nem tão distinto quanto tudo isso. Porém, meditando diligentemente sobre isso, recordo-me de haver sido muitas vezes enganado, quando dormia, por ilusões análogas" ${ }^{\circledR 1}$.

$\mathrm{Na}$ presente situação, em que se garante estar completamente desperto, consciente e atento a todas as ações e sensações, decidindo cada uma delas, Descartes reconhece suceder o mesmo em certos sonhos, onde se sentia tão desperto e consciente de si, de suas ações e sensações quanto agora. As experiências do agora são de tal maneira idênticas àquelas experimentadas no sonho que se torna impossível distinguir claramente se o agora é sonho ou se é realidade.

Esse trecho submete simultaneamente à dúvida as condições exigidas dos objetos e aquelas exigidas do sujeito. A respeito dos objetos, agora como no sonho, eles satisfazem as condições de proximidade e completa sensibilidade. No sonho, os sentidos têm a mesma sensação inequívoca dos objetos. Quanto ao sujeito, sua percepção sensível encontra-se no seu mais perfeito funcionamento, quer dizer que a percepção de estar desperto, consciente e atento a todas as ações e sensações ocorre de modo inconfundível, tanto que Descartes ressalta que estende a mão e que a sente. Seja no sonho seja no agora, e necessário preservar tais condições, a fim de que os sentidos, operando perfeitamente, produzam no sujeito um conhecimento verdadeiro.

Contudo, o recurso ao argumento do sonho mostra que o cumprimento dessas exigências não garante o resultado esperado. Com efeito, os sentidos se mostram incapazes de garantir que aquilo que percebem corresponde ao que existe efetivamente, pois, no sonho, acontece de se ter uma experiência sensível muito real do que não é real. Tomás de Aquino, aliás, já aludia, no século XIII, ao engano dos sentidos. Seguindo Agostinho, ele afirma que o problema dos sentidos é que só percebem o que é mutável e, como a verdade é imutável, não pode ser percebida por eles. Em razão do seu caráter mutável, não existe nenhuma coisa sensível que não encerre algo semelhante ao falso, impossibilitando-nos o discernimento. Diz ele:

\footnotetext{
$\overline{{ }^{81} \text { Primeira Meditação. AT IX, 14-15. }}$
} 
“Tudo quanto apreendemos através dos sentidos corporais, também quando as coisas não estão presentes aos sentidos, recebemos as imagens dessas coisas como se nos estivessem presentes, tal como acontece também no sono ou em acessos de furor. Ora, a verdade nada encerra em si que se assemelhe ao falso, logo não pode ser apreendida pelos sentidos" 82 .

Portanto, Tomás e Descartes concordam que na atividade onírica experimentamos os objetos tão presentes, próximos e tão sensíveis que não é possível discernir se eles são ou não reais. Descartes, porém, ressalta que no sonho como agora, ninguém pode negar a existência da percepção, quer dizer, que os sentidos percebem a existência de uma realidade exterior que os afeta. E ainda acrescenta:

"É necessário ao menos confessar que as coisas que nos são representadas durante o sono são como quadros e pinturas, que só podem ser formados à semelhança de alguma coisa real e verdadeira; e que, ao menos dessa maneira, essas coisas gerais, isto é, olhos, cabeça, mãos e todo o resto do corpo, não são coisas imaginárias, e sim verdadeiras e existentes" ${ }^{\prime 3}$.

Quando sonhamos, representamos no mais das vezes as mesmas coisas com as quais lidamos quando despertos. Do mesmo modo, no processo de abstração, a imaginação retém as imagens que são semelhantes àquilo que os sentidos captam. Quer sonhando quer desperto, toda representação sensível tem um fundamento real, isto é, toda representação é representação de alguma coisa verdadeiramente existente. Agora, Descartes pretende atacar o segundo nível da abstractio, quando a imaginação contém em si as imagens sensíveis dos objetos captados pelos sentidos.

Em linhas gerais, de acordo com o realismo, a imaginação, por meio dos sentidos externos, produz o fantasma, com o qual as coisas sensíveis se assemelham e sobre o qual o intelecto agirá para produzir as espécies inteligíveis, formando os universais. "Seu fundamento real consiste em que sua formação por meio do intelecto dependa, ao menos parcialmente, das coisas sensíveis" ${ }^{84}$. Todavia, se o universal, adquirido a partir das coisas sensíveis, decorre da abstração operada sobre o fantasma, deve-se assumir, a fim de que a relação entre intelecto e fantasma seja suficiente para

\footnotetext{
${ }^{82}$ Tomás de Aquino. Questões Discutidas sobre a Verdade, q. 1, a. 4.

${ }^{83}$ Primeira Meditação. AT IX, 15.

${ }^{84}$ M. Guerrero. O Processo de Abstração e o Fundamento Real dos Universais em Tomás de Aquino, p. 90.
} 
dar fundamento real ao universal no que concerne à sua origem, que o fantasma é sempre uma semelhança de coisas sensíveis realmente existentes ${ }^{85}$. Ao que Descartes alude, dizendo que são como quadros e pinturas, que só são formados à semelhança de alguma coisa real e verdadeira. Assim, para existir representação é necessário existir alguma coisa real, um fundamento real, que são as coisas verdadeiras e existentes e não imaginárias. Ora, se nada provém do nada, a representação só poderá provir de coisas reais e não imaginárias; ela pressupõe a coisa verdadeiramente existente, que será representada. Prova disso são os pintores que, mesmo representando quimeras por formas estranhas e excepcionais, são incapazes de lhes conferir formas e naturezas totalmente novas, antes fazem certa mistura e composição dos membros dos animais já vistos. Descartes ainda ressalta:

"se por acaso sua imaginação [a dos pintores] for suficientemente extravagante para criar algo tão novo, que nunca tenhamos visto, e que desta forma sua obra nos represente uma coisa puramente fictícia e absolutamente falsa, com certeza ao menos as cores com que eles a executam devem ser verdadeiras" ${ }^{\prime \prime 6}$.

Ora, se toda representação é representação de alguma coisa, nossas representações todas, mesmo as fictícias e falsas pressupõem algo verdadeiro a partir do qual se configure a representação. Qualquer representação que parta de outra coisa que não sejam as coisas gerais é por si só fictícia e absolutamente falsa. A imagem, por exemplo, de uma cadeira é produzida através da combinação e unificação das espécies sensíveis relativas à grandeza, aspereza, cor, profundidade, “de maneira que, nesse fantasma, diversas semelhanças recebidas nos sentidos estarão presentes sob a forma de uma semelhança intrinsecamente individual de algo que pode ser dado aos sentidos" ${ }^{87}$. Não cabe à imaginação criar as determinações sensíveis que compõem o fantasma; ela apenas utiliza essas determinações dadas nos sentidos. Acontece que a natureza ativa da imaginação é uma atividade interna da alma e, como tal, a imaginação tanto poderá formar imagens semelhantes às coisas sensíveis existentes fora da alma como poderá formar imagens que não correspondem a algo realmente existente. Sendo assim, não parece haver garantia de que as espécies inteligíveis, produzidas pelo intelecto, tenham fundamento real, isto é, que se originem nas coisas sensíveis existentes por serem

\footnotetext{
${ }^{85}$ Cf. M. Guerrero. Op. cit., 90-91.

${ }^{86}$ Primeira Meditação. AT IX, 15.

${ }^{87}$ M. Guerrero. Op. cit., p. 91.
} 
abstraídas do fantasma e não em ficções. Que fundamento real essas imagens subjetivas, algumas vezes formadas de modo totalmente arbitrário pela imaginação, são capazes de dar às espécies inteligíveis que delas são abstraídas? Não há, infelizmente, qualquer garantia de que as espécies inteligíveis se assemelhem efetivamente às naturezas corpóreas existentes na natureza ${ }^{88}$. Desta maneira, as coisas gerais podem muito bem ser imaginárias.

\subsection{Descoberta das coisas simples e universais e abandono do realismo}

No momento em que pretendemos mostrar a refutação cartesiana do realismo, a seguinte passagem, ao mesmo tempo em que introduz as coisas simples e universais e nos insere no terreno da dúvida metafísica, representa a chegada cartesiana ao último nível da abstractio, o qual também será submetido ao método da dúvida. Como os partidários da abstractio, Descartes encontra-se acima da imaginação, a saber, no interior do intelecto onde se localizam, segundo eles, as espécies inteligíveis. A menção cartesiana às "imagens no pensamento" e não mais na imaginação nos leva a crer que se trata não das espécies sensíveis localizadas na imaginação, e sim das espécies inteligíveis, a quidditas ou essência universal abstraída pelo intelecto:

"Mesmo que estas coisas gerais, isto é, olhos, cabeça, mãos e outras análogas, possam ser imaginárias, é necessário confessar que existem outras bem mais simples e universais, que são verdadeiras e existentes, de cuja mistura, nem mais nem menos que da mistura de algumas cores verdadeiras, são formadas todas essas imagens das coisas que se situam em nosso pensamento, quer verdadeiras e reais, quer fictícias e fantásticas. Desse gênero de coisas é a natureza corpórea em geral, e sua extensão; juntamente com a figura das coisas extensas, sua quantidade, ou grandeza, e seu número; como também o lugar em que se encontram, o tempo que mede sua duração e outras coisas análogas" $"$.

Tratando do debate entre Gueroult e Frankfurt em torno das coisas simples e universais, Forlin mostra que elas tanto podem ser consideradas meras condições necessárias de toda representação possível (no caso de não haver mundo material

\footnotetext{
${ }^{88}$ Cf. Idem.

${ }^{89}$ Primeira Meditação AT IX, 15.
} 
exterior) - tal é interpretação feita por Gueroult - quanto condições necessárias de toda coisa extensa possível (no caso da existência de um mundo material exterior) - que é a interpretação de Frankfurt". Forlin lembra que, como noções da mente, elas são propriedades essenciais das coisas extensas, independente do estatuto do mundo, isto é, tenha ele ou não existência exterior à mente. Dessa maneira, o que se deve afirmar "é que as coisas simples e universais são condições necessárias de todas as coisas extensas, sejam elas meras representações minhas ou coisas materiais exteriores a mim" $" 90$. Curiosamente, à mesma ponderação chegaram os teóricos da abstractio, mas tomavamna como um problema. Vejamos.

Segundo eles, é certo afirmar que ao operar sobre os fantasmas o intelecto produz as espécies inteligíveis. Mas isso não quer dizer que elas sejam semelhanças de coisas reais. Conforme explica Guerrero, "a posse de um conceito não implica a instanciação do mesmo, uma vez que a operação de intelecção não visa ao ser das coisas, mas às suas determinações formais" 91 e, assim, o fundamento real não consistiria apenas na produção de semelhanças. Quando a imaginação produz o fantasma, ela nada lhe acrescenta que já não estivesse presente, isoladamente, nas espécies sensíveis. Assim, do fato de as espécies inteligíveis serem extraídas dos fantasmas, garante-se que, a princípio, não haverá nada no conteúdo delas que não seja uma determinação possível de um objeto sensível. Guerrero conclui, dizendo:

"Ainda que as determinações inteligidas não se encontrem em nenhum objeto real, ao menos seria possível, em princípio, que elas estivessem concretizadas em sujeitos individuais [...] Em outras palavras, o fundamento real do universal, que decorre de o processo abstrativo dar-se por meio de uma certa relação entre intelecto agente e fantasmas, consiste em que o resultado desse processo seja efetivamente a semelhança de uma natureza corpórea, quer ela exista, quer não exista" ${ }^{92}$.

Ora, atento a essa questão, já no século XIII, Tomás visava justamente encontrar uma solução satisfatória. Sua teoria abstracionista pretendia explicar "como os universais, existindo apenas na alma e sendo produtos de uma atividade sua, poderiam

\footnotetext{
${ }^{90}$ E. Forlin. A Teoria Cartesiana da Verdade, p. 70 (todas as citações). Cf. também M. Gueroult. Descartes selon l'Ordre des Raisons, I, p. 36; H. Frankfurt. Demons, Dreamers and Madmen, p. 97-98.

${ }_{91}^{91}$ M. Guerrero. Op. cit., p. 92.

${ }^{92}$ Idem. Op. cit., p. 91.
} 
ainda assim ter algum fundamento real, ou seja, por que não se deveria considerá-los meros produtos ou caprichos da alma"93.

Sendo assim, Descartes e os partidários da abstractio chegam ao mesmo ponto, isto é, àquelas coisas tomadas como condição necessária de todas as coisas extensas, quer sejam meras representações, quer sejam coisas materiais exteriores ${ }^{94}$. As semelhanças, porém, acabam aí.

Nitidamente, Descartes opera uma distinção entre as coisas simples e universais e as imagens mentais. Aquelas são descritas como verdadeiras e existentes e nelas todas as nossas representações ou imagens formadas no nosso pensamento têm sua origem. Além de serem apresentadas como fonte originária e condição da existência das primeiras, elas também escapam ao arbítrio ou capricho do sujeito ${ }^{95}$. Em razão de sua resistência à dúvida natural, não há nada nelas que nos permita considerá-las duvidosas ou suspeitas de falsidade. Por isso, são verdadeiras e existentes. Agora como no sonho, elas se mantêm válidas, como ocorre no exemplo da adição de dois a dois formar quatro. Isso significa que resistem à arbitrariedade da vontade do sujeito, pois este, embora possa produzir representações fictícias e fantásticas na sua imaginação, não pode alterar as coisas simples e universais, por mais que se esforce. Por exemplo, não pode produzir um quadrado com mais de quatro lados nem pode conceber a possibilidade lógica do que é logicamente impossível. Sua necessidade constrange as faculdades humanas.

O realismo, ao contrário, insistindo no aprimoramento e preservação do fundamento real da abstractio, afirmava que as imagens mentais tinham origem numa realidade sensível apreendida pelos sentidos. As espécies inteligíveis não parecem conseguir se livrar da possibilidade de serem produzidas por capricho da alma ou arbítrio do sujeito. Consequentemente são duvidosas, quer consideremos seu fundamento real, isto é, sua origem numa realidade exterior existente que se dá ao intelecto através dos sentidos, quer consideremos o sujeito, pois os próprios partidários da abstractio reconhecem que elas poderiam ser produzidas pela faculdade imaginativa. Torna-se, portanto, impossível conhecer verdadeiramente as coisas a partir dos sentidos

\footnotetext{
${ }^{93}$ M. Guerrero. Op. cit., p. 70.

${ }^{94}$ Cf. E. Forlin. A Teoria Cartesiana da Verdade, p. 70.

95 A caracterização das coisas simples e universais por Descartes se assemelha muito à caracterização dos Paradigmas em si e por si de Platão, pois ambos afirmam que não são forjados pelos caprichos de qualquer sujeito nem estão submetidos ao devir. Diferentemente de Platão, Descartes não as considera em si nem por si, mas originadas de uma causalidade eficiente e não exemplar, afastando-se igualmente dos pensadores cristãos, tal como veremos oportunamente.
} 
ou da experiência sensível. Aliás, Descartes assinala que as ciências que dependem das coisas compostas manifestam-se dúbias e incertas ${ }^{96}$. Coerente com o método adotado, e ante os indícios de dúvida encontrados, é necessário rejeitar todo o aparato teórico realista assentado na tese segundo a qual tudo o que se admite como verdadeiro e certo advém dos sentidos ou através dos sentidos ${ }^{97}$.

\footnotetext{
96 “Talvez seja por isso que nós não concluamos mal se afirmarmos que a física, a astronomia, a medicina e todas as outras ciências dependentes da consideração das coisas compostas são muito dúbias e incertas". Primeira Meditação. AT IX, 16.

${ }^{97}$ Cf. Primeira Meditação. AT IX, 13.
} 


\section{CAPÍTULO SEGUNDO \\ APRECIAÇÃO DUBITATIVA \\ DO IDEALISMO}




\subsection{Considerações preliminares}

A apreciação dubitativa do realismo conduziu à descoberta das coisas simples e universais. Além de distintas das imagens no pensamento, que podem ser forjadas pelos caprichos da alma, elas foram apresentadas como condição das nossas representações e da realidade material, exista ou não alguma realidade material. A grande questão agora é descobrir se as coisas simples e universais têm ou não uma origem e, caso tenham, qual seria, porque, com a destruição da abstractio pela apreciação dubitativa do realismo, ficou descartada a possibilidade de uma origem sensível.

Buscando o fundamento causal das coisas simples e universais, Descartes submete o idealismo à apreciação dubitativa, tendo em vista pelo menos duas hipóteses explicativas para a existência delas. A primeira, fiel ao idealismo platônico, tomá-las-ia como realidades verdadeiras, necessárias e subsistentes por si externamente a Deus e, portanto, independentes dele. A segunda, iniciada pelo medioplatonismo com a transformação das Formas platônicas em pensamentos de Deus, cuja influência foi determinante para o pensamento cristão, preservá-las-ia como realidades e verdades subsistentes não fora, mas internamente a Deus ${ }^{98}$.

Muito antes de Descartes, uma solução a esse problema teria sido apresentada por Ockham, o qual, segundo nota Chaui, foi responsável por causar um impacto irreversível na tradição, causado pela ruptura com a tradição medieval ${ }^{99}$. Ockham pôs fim à existência das essências arquetípicas situadas no intelecto divino. Se para a escolástica Deus cria as coisas por meio de essências ou modelos universais localizados

\footnotetext{
98 Desde a introdução platônica das Formas ou Paradigmas até Descartes, essas realidades assumiram diversos nomes na História da Filosofia como arquétipos ou exemplares, essências ou verdades eternas. Inicialmente, foram concebidas como realidades subsistentes por si mesmas. Graças ao medioplatonismo, passaram a subsistir no intelecto divino. Aliás, não seria exagero dizer que a operação medioplatônica de transpor as Ideias para o interior da mente divina foi uma solução muito engenhosa para preservá-las tais como eram, mudando-as apenas de "lugar", ou seja, do Hiperurânio para intelecto divino, que mais parece uma mudança nominal. Na verdade, a doutrina das Formas separadas, por cuja participação as coisas existem, é inconciliável com a fé cristã. Com efeito, seria muito estranho reconhecer ou atribuir às Ideias algum poder criador. Em razão disso, as Formas platônicas passaram a subsistir na mente divina. Ademais, assim como as Ideias delimitavam a ação artística do demiurgo, os arquétipos ou exemplares, as essências ou verdades eternas delimitavam igualmente a ação criadora divina. $\mathrm{O}$ demiurgo as contemplava externamente. Imprimindo forma à matéria incriada, plasmava o mundo à semelhança do que contemplava. O cristianismo julgava essa explicação deveras problemática e afirmava que, na verdade, Deus contemplava as essências, não externamente, mas no seu próprio intelecto, e, ex nihilo, criava o mundo em conformidade com elas. Assim, deixavam de ser realidades independentes e subsistentes por si mesmas, passando a depender do intelecto divino, precedendo e orientando a vontade onipotente.

${ }^{99}$ Cf. M. Chaui. A Nervura do Real, p. 343.
} 
em seu intelecto, para Ockham a criação é imediata, pondo fim ao exemplarismo ${ }^{100}$. Existem apenas as substâncias singulares, criadas imediatamente pela onipotência divina. Deus as conhece enquanto singulares.

Suárez, por sua vez, como os nominalistas, admite a existência das coisas individuais. No entanto, essas coisas são individuadas devido à própria entidade delas, antes mesmo de serem causadas pela onipotência divina, através de sua aptidão para ser, isto é, de sua possibilidade ou essência anterior à criação. As coisas individuais são unitárias, o que implica que não pode haver universal in re realmente distinto da coisa. Donde resulta que o universal, enquanto algo que participa de muitas coisas só pode existir atualmente se tal se der apenas objetivamente no intelecto. Como não há, de maneira ontologicamente positiva, espécies ou gêneros, Deus conhecerá as coisas com base nos indivíduos possíveis ${ }^{101}$. Nesse sentido, Suárez se aproxima e se distancia dos nominalistas. Distancia-se quando admite o universal na coisa, mas se aproxima ao atribuir o universal à coisa em função de uma denominação extrínseca. Isso significa que os universais não são positivamente eternos, posto não terem efetividade, existência real, mas enquanto abstração no intelecto.

A posição suareziana poderia nos fazer pensar que ele admite, dada a localização dos universais no intelecto, sua eternidade por dependência de Deus, seguindo a posição, por exemplo, de Tomás de Aquino. Entretanto, nas Disputas Metafísicas (DM), ao tratar das enunciações sobre verdades perpétuas, tal impressão se desfaz. Na $D M$ XXXI, conforme a explicação de Marion, Suárez chama a atenção para a análise de verdades necessárias e contingentes. Se elas residem no intelecto divino, não deve ser segundo a mesma necessidade. Observa que as verdades contingentes possuem uma relação com este intelecto de uma maneira muito diferente das necessárias. Aquelas supõem o tempo de sua efetividade; estas não são condicionadas, ou seja, sua necessidade incondicionada pode ser considerada uma necessidade absoluta. "A absoluta necessidade indica que nenhuma condição contingente deve ser satisfeita por uma instância não lógica para que a verdade lógica seja absolutamente verdadeira"102 . O Doutor Exímio, ao anunciar que as verdades necessárias "são simplesmente necessárias e sem condição", recusa-se a aceitar posições que as façam depender das faculdades divinas. Por causa do pressuposto da individuação em razão da própria entidade da coisa

\footnotetext{
${ }^{100}$ Cf. Ockham. Philosophical Writings, p. 20.

${ }^{101}$ Cf. A. R. Rios. Ensaios sobre Suárez e Descartes, p. 66.

102 J.-L. Marion. Sur la Théologie Blanche de Descartes, p. 45.
} 
antes de sua criação, ele só poderia admitir a dependência de uma coisa de Deus por meio da criação. Ao longo da $D M$ XXXI, Suárez tece cuidadosamente a tese da não criação das verdades eternas, declarando que são eternas porque dispensam a causalidade eficiente. Isso significa que não foram causadas por Deus, nem mesmo como causa exemplar, o que the permitia concluir que as verdades eternas "não são verdadeiras porque conhecidas por Deus, ao contrário são precisamente conhecidas devido à sua própria verdade. De outro modo, seria impossível dar qualquer razão pela qual Deus conhecesse necessariamente sua verdade, pois se sua verdade procedesse de Deus mesmo, esta só poderia proceder por intermédio da vontade de Deus, assim não procederia da necessidade, mas da vontade" ${ }^{\prime 103}$. Ora, segue-se disso que as verdades eternas não procedem de Deus, o que levou Descartes a ver em Suárez um teólogo que sustenta a existência das verdades eternas independentes de Deus ${ }^{104}$.

Como se verá, a certeza cartesiana da existência de um fundamento causal para as coisas simples e universais, verdadeiras e existentes, implicará na rejeição das duas hipóteses mencionadas, por admitirem algo precedendo e limitando a onipotência divina externa ou internamente. Para determinar a causa das coisas simples e universais, Descartes recorrerá às instâncias metafísicas superiores. Lançando dúvidas sobre cada uma delas, pretende revelá-las como falsos e imperfeitos fundamentos causais. Sob essa ótica, ficamos diante de uma curiosa questão, a saber, seriam as coisas simples e universais duvidosas em si mesmas ou tornar-se-iam duvidosas porque derivadas de falsas causas? Isto porque só somos obrigados a duvidar delas quando vinculadas a causas duvidosas, pouco poderosas e, principalmente, imperfeitas.

Ora, se as imagens formadas no pensamento têm origem nas coisas simples e universais, como são formadas, ou melhor, qual é a origem causal destas últimas? Destruídos o realismo e a abstractio, não se pode dizer que elas se originam diretamente ou por intermédio dos sentidos numa realidade exterior, a qual já não se sabe se existe. São verdadeiras independentemente da existência da realidade material e, por isso mesmo, não há nada nelas de duvidoso ou suspeito de falsidade, o que explica o caráter incontestável das matemáticas:

“...a aritmética, a geometria e as outras ciências desta natureza, que só se dedicam a coisas bastantes simples e gerais, sem se preocuparem muito se elas

\footnotetext{
${ }^{103}$ F. Suárez. DM XXXI, s. 12, § 40.

${ }^{104}$ Cf. A Mersenne. AT I, 149.
} 
existem ou não na natureza, encerram alguma coisa de certo e incontestável. Portanto, quer eu esteja acordado, quer esteja dormindo, dois mais três formarão sempre o número cinco e o quadrado jamais terá mais do que quatro lados; e não parece possível que verdades tão evidentes possam ser suspeitas de alguma falsidade ou dúvida"105.

\subsection{Buscando o significado das coisas simples e universais}

Na Primeira Meditação, é feita uma distinção entre as coisas simples e universais e as coisas gerais. Embora distintas, ambas são consideradas coisas. Coisa é um termo importante em Descartes. Nós o analisamos quando tratamos da teoria da livre criação das verdades eternas, observando como, por meio dele, a noção de verdade eterna apresentada na Correspondência abrange desde as noções comuns até as essências tantum verae aut possibiles. Agora o termo reaparece, trazendo consequências significativas para a compreensão das coisas simples e universais e da teoria cartesiana da criação. Vejamos.

No artigo 48 dos Princípios, Descartes distingue entre a coisa, a afecção da coisa e a verdade eterna, frisando que esta última só existe no pensamento:

“Tudo o que cai sob nossa percepção, nós o consideramos ou bem um coisa [res] ou uma certa afecção da coisa ou bem como uma verdade eterna que não tem qualquer existência fora do pensamento" $" 106$.

No artigo seguinte, declara que as verdades eternas correspondem às noções comuns ou máximas, cuja noção não envolve a existência extramental, ao contrário da noção de coisa, da qual ele afirma existir externamente:

"Visto que reconhecemos que não pode ocorrer que a partir do nada algo venha a ser, então esta proposição - a partir de nada nada vem a ser - é considerada não como alguma coisa existente [res aliqua existens], nem tampouco como um modo da coisa, mas como uma certa verdade eterna que tem sede em nossa mente e se chama noção comum ou ainda axioma" ${ }^{\text {"107. }}$.

\footnotetext{
105 Primeira Meditação. AT IX, 16.

${ }^{106}$ Princípios, art. XLVIII.

${ }^{107}$ Ibidem, art. XLIX.
} 
Com a distinção entre coisa e verdade eterna fica impedida a inserção das noções comuns do entendimento entre as coisas simples e universais, uma vez que as primeiras não têm nenhuma importância existencial, enquanto as segundas remetem à existência ${ }^{108}$. O conceito de coisa, no entanto, não se refere exclusivamente à existência atual, mas designa também a realidade objetiva da ideia, isto é, a realidade do conteúdo representado enquanto representado, conforme atesta o trecho a seguir:

"Dentre os conteúdos que consideramos como coisas, os mais gerais são a substância, a duração, a ordem, o número e, se é que há outros do mesmo tipo, os que se estendem a todos os gêneros de coisas" ${ }^{\prime 109}$.

Esse trecho, porém, poderia nos induzir a assimilar as coisas simples e universais às ideias, o que é rejeitado pela Terceira Meditação quando afirma que estas últimas são tão somente imagens das coisas: "entre os meus pensamentos, alguns são como as imagens das coisas, e é somente a estes que convém propriamente a denominação de ideia"110, distinguindo, assim, a ideia de seu conteúdo. Portanto, as coisas simples e universais se distinguem das ideias. Posso ter ideias de coisas simples e universais, mas isso jamais me autorizaria a identificá-las entre $\mathrm{si}^{111}$. Vamos às Regras, onde o filósofo se propõe a tratar do assunto de forma mais detalhada.

Na Regra VIII, completada pela XII, ele trata detidamente das coisas simples e universais, dando-nos uma ideia de que as entende por naturezas, o que é coerente com o trecho da Primeira Meditação, pois entre os exemplos citados como coisas simples e universais, encontra-se a "natureza corpórea em geral"" que maneira "chegar às coisas mesmas", Descartes afirma que só se deve considerá-las

\footnotetext{
${ }^{108}$ Cf. H. Gouhier. La Pensée Métaphysique de Descartes, p. 271.

${ }^{109}$ Princípios, art. 48.

${ }^{110}$ AT IX, 29.

111 Gueroult, no contexto da discussão sobre a teoria cartesiana da criação das verdades eternas, tinha afirmado que "as ideias são naturezas ou essências que envolvem a possibilidade de existência" (M. Gueroult. Descartes selon l'Ordre des Raisons, II, p. 22-23). Mesmo que tal assimilação tivesse bons propósitos, a saber, o de elencar uma classe de verdades inatingíveis pela teoria da livre criação, fato é que Descartes não autoriza fazê-lo, tal como se verifica ainda na seguinte passagem extraída da Quinta Meditação: "E o que, aqui, estimo mais considerável é que encontro em mim uma infinidade de ideias de certas coisas que, embora talvez não tenham nenhuma existência fora de mim, não podem ser consideradas um puro nada; e, embora esteja, de certa forma, em minha liberdade pensá-las ou não as pensar, não são, entretanto, formadas por mim, mas possuem elas mesmas naturezas verdadeiras e imutáveis" (AT IX, 51). As ideias são, portanto, ideias de coisas. Estas, sim, são uma certa natureza eterna e imutável.

${ }^{112}$ Primeira Meditação. AT IX, 15.
} 
na medida em que o entendimento as atinge. Em seguida, ele designa essas coisas por naturezas totalmente simples, pelas quais entende "as naturezas espirituais, ou corporais ou que se reportam às duas a um só tempo" ${ }^{113}$, prometendo uma exposição detalhada na Regra XII.

Chegando à Regra XII, ele diz que, considerando as coisas que caem sob a percepção do entendimento, denominam-se "simples somente aquelas cujo conhecimento é tão nítido e tão distinto que a inteligência não pode dividi-las em várias outras conhecidas mais distintamente: assim são a figura, a extensão, o movimento etc." 114 . Em seguida, considerando-as em relação ao entendimento, ele as distingue em três tipos de coisas. Primeiro, as puramente intelectuais que são conhecimento, dúvida, volição etc., seguidas das puramente materiais que são figura, extensão e movimento, por exemplo, e, finalmente, as comuns "atribuídas ora aos objetos corporais, ora aos espíritos, sem distinção, como a existência, a unidade, a duração, e coisas semelhantes" 115 . Em nenhum desses casos são mencionadas as noções comuns como coisas simples. No entanto, na continuação do trecho que acabamos de citar, diz-se que as noções comuns "são como que vínculos que unem outras naturezas simples entre si e sobre cuja evidência se apoiam todas as conclusões dos raciocínios" ${ }^{\text {116 }}$. Do que se pode concluir que as noções comuns, embora simples, não são elas próprias coisas ou propriedades das coisas $^{117}$.

Conforme apresentou-nos os Princípios, as noções comuns não são coisas, mas verdades eternas que "não têm qualquer existência fora de nosso pensamento"118. Quando se refere às coisas simples e universais na Primeira Meditação, Descartes deixa claro que se trata de coisas "verdadeiras e existentes", cujo sentido se aproxima demais da expressão "res aliqua existens" usada no artigo 49 dos Princípios, das quais formamos as imagens no pensamento e cuja existência não é, em hipótese alguma, puramente mental. Ademais, conforme ressalta Forlin, as noções comuns, porque servem de elo puramente conceitual, não introduzem nenhuma coisa ao pensamento, mas são aplicadas a qualquer coisa ${ }^{119} \mathrm{e}$, finalmente, elas só existem no pensamento.

\footnotetext{
113 Descartes. Regras para a Orientação do Espírito, Regra VIII, p. 55.

${ }^{114}$ Ibidem. Regra XII, p. 82.

115 Ibidem, p. 84.

116 Idem.

117 Cf. E. Forlin. A Teoria Cartesiana da Verdade. p. 322-323. Gouhier observa que "a expressão natureza simples abrange de uma só vez realidades e verdades: as noções comuns servem de ligação entre res consideradas, também elas, naturezas simples" (H. Gouhier. Op. cit., p. 274).

118 AT IX, art. 48.

${ }^{119}$ Cf. E. Forlin, Op. cit., 325.
} 
Entretanto, uma vez que as coisas simples e universais não são nem ideias nem noções comuns, resta-nos investigar se elas poderiam corresponder às essências, ou melhor, às verdades eternas apresentadas nas cartas.

\subsubsection{Coisas simples e universais como essências}

De acordo com as cartas de 1630, Descartes afirma entender por essências as verdades eternas que sunt tantum verae aut possibiles ${ }^{120}$, e as entende como coisa:

"pois é certo que ele [Deus] tanto é autor da essência como da existência das criaturas: ora, esta essência outra coisa não é que as verdades eternas; as quais eu não concebo emanar de Deus como os raios do sol, mas eu sei que Deus é o autor de todas as coisas, e que estas verdades são alguma coisa e, por conseguinte, que ele é seu autor" ${ }^{\prime 121}$.

Essa observação é necessária, porque se as coisas simples e universais equivalerem às essências - que as cartas chamam de verdades eternas -, então serão equivalentes às verdades eternas. No entanto, não serão equivalentes às noções comuns ou máximas do entendimento - que os Princípios chamam de verdades eternas -, porque a compreensão cartesiana das coisas simples e universais, conforme mostramos anteriormente, impede sua assimilação às noções comuns e às ideias. Tudo indica que essa interpretação é autorizada por Descartes. Com efeito, segundo as cartas, entre as verdades eternas contam-se as verdades matemáticas, evocadas pela Primeira Meditação como coisas simples e universais ${ }^{122}$.

Mas qual é o significado cartesiano de essência? De acordo com Gueroult, essências são as coisas existentes exteriormente e criadas por Deus ${ }^{123}$. No contexto da Primeira Meditação, as coisas simples e universais, apresentadas como necessárias e certas são, por enquanto, possíveis para a inteligência, do que não se segue que sejam

\footnotetext{
${ }^{120}$ A Mersenne, 2 de maio de 1630. AT I, 149.

${ }^{121}$ A Mersenne, 27 de maio de 1630 . AT I, 152.

122 “As verdades matemáticas, que vós nomeais eternas, foram estabelecidas por Deus e dele dependem inteiramente, assim como todo o resto das criaturas". (A Mersenne, 15 de abril de 1630. AT I, 145). "a aritmética, a geometria e as outras ciências desta natureza, que só se dedicam a coisas bastante simples e gerais, sem se preocuparem muito se elas existem ou não na natureza, encerram alguma coisa de certo e incontestável. Portanto, quer eu esteja acordado, quer esteja dormindo, dois mais três formarão sempre o número cinco e o quadrado jamais terá mais do que quatro lados; e não parece possível que verdades tão evidentes possam ser suspeitas de alguma falsidade ou dúvida" (Primeira Meditação. Cf. AT IX, 16).

${ }^{123}$ M. Gueroult. Descartes selon l'Ordre des Raisons, v. I, p. 374.
} 
essências, explica ${ }^{124}$. Todavia, uma passagem das cartas evidencia que essas essências ou verdades eternas são também os possíveis:

"Quanto às verdades eternas eu digo que são tanto verdadeiras ou possíveis somente porque Deus as conhece como verdadeiras ou possíveis. Ao contrário, porém, não digo que elas são conhecidas por Deus como verdadeiras, como se se tratasse de verdades existentes independentemente dele"125.

Ademais, conforme a teoria da livre criação das verdades eternas, as verdades eternas verae aut possibiles são dependentes de Deus. Ora, depender de Deus significa tê-lo como seu autor, ou seja, ter sido criado por ele ${ }^{126}$. A tese da criação das essências possíveis é um problema inerente à "teoria das cartas". Como criar, mesmo em Descartes, é posição de existência exterior, as coisas simples e universais até podem ser consideradas possíveis, mas isso não significará que não sejam criadas, a menos que se queira tratá-las como verdades existentes independentes de Deus e de sua vontade.

Ademais, a interpretação gueroultiana de essência precisa esclarecer o problema de como Descartes, de um lado, defende que as essências são os existentes criados e, de outro, afirma a existência de naturezas verdadeiras, imutáveis e eternas ${ }^{127}$. Segundo Gueroult, isso é algo perfeitamente compreensível, quando se leva em consideração que a essência, enquanto concebida por nós, é uma verdade eterna, mas isso não implica em que sua existência fora de nós seja como uma coisa eterna, pois fora de nós essa essência pode deixar de existir ${ }^{128}$.

Admitindo-se ou não a equivalência das coisas simples e universais às essências, a interpretação de Gueroult não parece levar em consideração o fato de que elas não correspondem às verdades eternas, segundo a definição dos Princípios, porque aí equivalem às noções comuns; nem correspondem às ideias, pois estas são como que imagens das coisas, conforme mostramos acima. Assim, restaria admitir apenas a existência das coisas simples e universais fora do pensamento.

\footnotetext{
${ }^{124}$ Cf. Ibidem, p. 38-39.

125 A Mersenne, 6 de maio de 1630. AT I, 149.

126 "pois é certo que ele [Deus] tanto é autor da essência como da existência das criaturas: ora, esta essência outra coisa não é que as verdades eternas; as quais eu não concebo emanar de Deus como os raios do sol, mas eu sei que Deus é o autor de todas as coisas, e que estas verdades são alguma coisa e, por conseguinte, que ele é seu autor" (A Mersenne. 27 de maio de 1630. AT I, 152).

${ }^{127}$ Cf. AT IX, 51.

${ }^{128}$ Cf. M. Gueroult. Op. cit. I, p. 376.
} 
As noções comuns são verdades eternas, mas não equivalem a essências, do mesmo modo que não equivalem a coisas, quer consideremos os artigos 48 e 49, quer consideremos as Regra VIII e XII ${ }^{129}$. Assim, a consideração cartesiana das essências como coisa é a única que se identifica à consideração das coisas simples e universais como coisa, ou seja, como tendo ou podendo ter existência extramental, como "res aliqua existens" ${ }^{\prime 130}$, estando excluídas as noções comuns e as ideias.

Agora, consideremos que as coisas simples e universais são "necessárias e certas", como diz Gueroult, ou "realidades e verdades", segundo Gouhier, todas elas "conhecidas por si só e que não contêm nada de falso"131, naturezas "verdadeiras e existentes", "eternas e imutáveis" e deixemos de lado a instauração da dúvida metafísica. Nessas circunstâncias, elas não parecem ser coisas subsistentes por si e incausadas, cuja necessidade e verdade procedem delas mesmas? Como tais preocupações Descartes já manifestara nas cartas, considerando blasfema toda tese que admitisse que alguma coisa seria capaz de existir independentemente de Deus ${ }^{132}$, ou seja, sem que tivesse Deus como causa eficiente de sua existência ${ }^{133}$, agora, a introdução da dúvida metafísica pode ser o caminho para evidenciar a necessidade de um fundamento causal legítimo, do qual procedem todas as coisas verdadeiras e necessárias. Passaremos agora à análise da difícil questão do estatuto de realidade das coisas simples e universais.

\subsubsection{Sobre o estatuto de realidade das coisas simples e universais}

O problema resulta da afirmação cartesiana de que as coisas simples e universais são verdadeiras e existentes. Antes de prosseguir, reiteremos o fato de que essas coisas não são noções comuns tampouco ideias, e levemos em consideração a equivalência entre coisas simples e universais e verdades eternas, tal como descrevemos acima, a

\footnotetext{
${ }^{129}$ Isso não quer dizer que as noções comuns escapem do alcance do poder criador. A teoria da livre criação das verdades eternas defende a criação tanto das noções comuns quanto das essências.

${ }^{130}$ Princípios, art. XLIX.

131 Regra XII, p. 85.

132 "As verdades matemáticas, que vós nomeais eternas, foram estabelecidas por Deus e dele dependem inteiramente, assim como todo o resto das criaturas. É, com efeito, falar de Deus como um Júpiter ou Saturno, e sujeitá-lo ao Estige e aos Destinos, dizer que essas verdades são independentes dele". (A Mersenne, 15 de abril de 1630. AT I, 145. Veja-se também AT I, 149).

${ }^{133}$ Cf. Quartas Respostas, AT IX, 186.
} 
saber, correspondendo às essências tantum verae aut possibiles, designadas como coisa $^{134}$, verdades existentes dependentes de Deus ${ }^{135}$. Prossigamos.

Analisando a questão, Frankfurt se interroga pelo sentido da asserção cartesiana, segundo a qual as coisas simples são verdadeiras ou existem. Segundo ele, a afirmação cartesiana da existência das coisas simples e universais leva muitos a interpretarem "esta existência de tal maneira que aquela dos objetos materiais não lhe esteja ligada de modo algum" ${ }^{\prime 136}$, desvinculando, desse modo, as coisas simples e universais da realidade material.

Alternativamente, Frankfurt as entende como existindo na própria realidade material, como característica ou sua propriedade ${ }^{137}$. Do contrário, aconteceria de as ideias das coisas simples não corresponderem à realidade material que caracterizam e da qual são propriedades, ou serem reduzidas a ideias ou consideradas realidades existentes em si mesmas, ou seja, realidades separadas do mundo material de que é propriedade ${ }^{138}$.

Em contrapartida, Forlin observa que Frankfurt se engana ao "tomar por certo aquilo mesmo que está em questão, a saber, a materialidade do mundo" ${ }^{139}$, advertindo que o significado da palavra existência não nos autoriza a pensá-la como realidade material, porque Descartes mesmo afirma claramente que as matemáticas tratam de coisas simples e universais sem dar qualquer importância a se elas existem ou não na natureza:

"Ora, se as coisas simples e universais podem, independentemente de qualquer correspondência com uma realidade exterior, garantir a verdade das matemáticas, então é porque elas próprias são verdadeiras, independentemente dessa correspondência"140.

O alvo da crítica de Frankfurt é Gueroult, que interpreta as coisas simples e universais como condição necessária de toda representação possível ${ }^{141}$. Assim, elas não podem ser elaboradas a partir de qualquer objeto sensível e, por isso, são simples. Por outro lado, salienta:

\footnotetext{
${ }^{134}$ Cf. A Mersenne, 27 de maio de 1630. AT I, 152.

${ }^{135}$ Cf. A Mersenne, 6 de maio de 1630. AT I, 149.

${ }^{136}$ H. Frankfurt. Demons, Dreamers and Madmen, p. 95-96.

${ }^{137}$ Ibidem, p. 97-98.

${ }^{138}$ Ibidem, p 100.

${ }^{139}$ E. Forlin. Op. cit., p. 67.

${ }^{140}$ Ibidem, p. 64.

${ }^{141}$ M. Gueroult. Descartes selon l'Ordre des Raisons, I, p. 36.
} 
"Quanto à possibilidade de serem formadas a partir de materiais não sensíveis, mesmo que isso seja inteligível, nenhum desses materiais pode ser considerado por Descartes neste estágio das Meditações, onde ele ainda supõe que todo conhecimento é de origem sensível. Em todo caso, Gueroult não fornece nenhuma evidência de sua interpretação" ${ }^{\text {,142 }}$.

Curiosamente, Frankfurt não recusa essa possibilidade de interpretação, apenas contesta a validade da interpretação de Gueroult, por carecer de provas. Entretanto, não são as coisas simples e universais, como sugere Frankfurt, que seriam formadas a partir de materiais não sensíveis. Ao contrário, Descartes afirma peremptoriamente que as imagens das coisas que se situam em nosso pensamento são formadas a partir das coisas simples e universais, que são verdadeiras e existentes ${ }^{143}$, quer dizer que as coisas simples e universais seriam elas mesmas os materiais não sensíveis - para usar os termos de Frankfurt -, cuja existência Descartes não vincula à existência da realidade sensível $^{144}$, mas a coloca como condição necessária da existência desta. As coisas simples e universais, portanto, são realidades não sensíveis, condição de possibilidade tanto de nossas representações quanto da existência do mundo material ${ }^{145}$.

Quanto ao argumento segundo o qual Descartes não pode considerar esses materiais nesta etapa das Meditações, porque ainda supõe que todo conhecimento é de origem sensível, ele não nos parece válido nesta etapa, se por ela entendemos o estágio da dúvida metafísica, mas o é, como mostramos, na etapa anterior, ou seja, a da apreciação dubitativa do realismo, cuja invalidação da abstractio acarretou tanto a queda do princípio de que todo o conhecimento tem origem diretamente dos sentidos ou através deles quanto conduziu à descoberta das coisas simples e universais, cujo caráter certo e indubitável sugere sua origem em algo não sensível. Nesse estágio, a meditação

\footnotetext{
${ }^{142}$ H. Frankfurt. Demons, Dreamers and Madmen, p. 78.

143 "Mesmo que estas coisas gerais, isto é, olhos, cabeça, mãos e outras análogas, possam ser imaginárias, é necessário confessar que existem outras bem mais simples e universais, que são verdadeiras e existentes, de cuja mistura, nem mais nem menos que da mistura de algumas cores verdadeiras, são formadas todas essas imagens das coisas que se situam em nosso pensamento, quer verdadeiras e reais, quer fictícias e fantásticas". (Primeira Meditação. AT IX, 15).

${ }^{144}$ Isso fica patente ao evocar as matemáticas, as quais "se dedicam a coisas bastante simples e gerais, sem se preocuparem muito se elas existem ou não na natureza, encerram alguma coisa de certo e incontestável" (Primeira Meditação. AT IX, 16).

${ }^{145} \mathrm{O}$ que também é acentuado por Forlin, ao concluir dizendo que "se o mundo material exterior não existir, as coisas simples e universais serão, de fato, condições necessárias de toda representação possível, mas também serão, de direito, condições de possibilidade da existência do mundo material; quer dizer, se existisse ou viesse a existir um mundo material, ele necessariamente deveria ser constituído pelas coisas simples e universais das quais temos noções em nossa mente" (E. Forlin. Op. cit., p. 70).
} 
cartesiana nos desloca para outra perspectiva do problema: se as coisas simples existem e não provêm dos sentidos, qual será antão a sua causa originária?

Em se tratando de uma questão legítima, o problema do estatuto de realidade das coisas simples e universais persiste independentemente do uso frouxo do vocábulo “existentes", empregado exclusivamente na tradução francesa das Meditações, ou seja, mesmo que o vocábulo "existentes" não se encontrasse na tradução francesa, mesmo assim, haveria problema ${ }^{146}$. Dessa maneira, o verdadeiro problema, e que será posto à prova pela dúvida metafísica, refere-se propriamente ao caráter idealista conferido às coisas simples e universais, estimadas como realidades subsistentes por si, absolutamente independentes, ou mais precisamente, incausadas, após a destruição do realismo. Com efeito, tudo o que dispensa a vontade de Deus como causa eficiente é, de acordo com Descartes, independente ${ }^{147}$. Ora, se as coisas simples e universais não são produzidas por nós, se também não são ideias, menos ainda noções comuns, então sua situação momentânea é idêntica à das Formas platônicas ou das verdades eternas suarezianas, correspondendo a coisas verdadeiras e existentes por si, independentes de Deus, cujo poder é constrangido pela necessidade proveniente delas mesmas.

\subsection{A instauração da dúvida metafísica e a necessidade do fundamento causal}

Tradicionalmente, a análise da estratégia cartesiana feita pelos intérpretes do cartesianismo enfatiza, com a chegada às coisas simples e universais, a impossibilidade de a razão conseguir duvidar delas. Assim, para levar a dúvida à sua total radicalidade, Descartes coloca a própria razão sob suspeita, por meio da dúvida metafísica ${ }^{148}$, cujos instrumentos são a hipótese do Grande Enganador, ou a ficção do Gênio Maligno. Em

\footnotetext{
${ }^{146}$ Aliás, Gueroult salienta que Baillet “estima que a tradução francesa revista por Descartes, é preferível ao próprio original, porque o autor, em vista de esclarecer certas passagens latinas não muito claras fez algumas pequenas mudanças, corrigindo-se a si mesmo" (Baillet. Vie de M. Descartes, I, VI, cap. IX, p. 172, apud. M. Gueroult. Op. cit., p. 34).

147 "Vós me perguntais por qual gênero de causa Deus estabeleceu as verdades eternas? Eu vos respondo que foi pelo mesmo gênero de causa que ele criou todas as criaturas, isto é, ut efficiens \& totalis causa", ou seja, como causa eficiente e total [...] Vós me perguntais o que Deus fez para produzi-las? Eu digo que no mesmo ato pelo qual ele as quis e as compreendeu [as verdades eternas] desde toda a eternidade, ele as criou, ou bem (se vós atribuís a palavra creavit (criou) somente à existência das coisas), ele as estabeleceu e as fez. Pois em Deus é uma e a mesma coisa querer, entender e criar (A Mersenne, 27 de maio de 1630. AT I, 152).

148 "Se o que se busca é uma certeza absoluta que tenha fundamento na própria realidade das coisas, isto é, uma certeza metafísica, então nada mais apropriado do que levantar uma dúvida metafísica, isto é, dúvida que questione a capacidade racional de apreender a realidade em si mesma: seria aquilo que é necessário para a razão uma necessidade real das coisas? A razão não pode estar sendo vítima de uma grande ilusão? A evidência racional não é uma farsa?" E. Forlin. O Ser da Ciência e a Ciência do Ser na Filosofia de Descartes, p. 110-111.
} 
face disso, muitos seguem o caminho proposto por Gueroult, qual seja o de analisar o problema da origem e do fundamento desses instrumentos da dúvida ${ }^{149}$.

Tomando uma perspectiva cosmológica, seguiremos por outra trilha, pois não nos propomos a investigar nem a origem nem o fundamento da hipótese do Deus enganador ou da ficção do gênio maligno. Com efeito, tendo presente à memória que as coisas simples e universais permanecem, por enquanto, em uma situação de autossuficiência, como realidades subsistentes por si mesmas, a instauração da dúvida metafísica se nos apresenta como uma investigação de sua origem e seu fundamento causal, por meio da seguinte estratégia. Primeiro são identificadas algumas instâncias metafísicas superiores apontadas como prováveis causas da origem e do fundamento das coisas simples e universais. Em seguida, essas instâncias são submetidas à verificação da dúvida por meio da qual se descobre seu caráter duvidoso. Evidenciadas como duvidosas e falsas, tornam também duvidosas e falsas as coisas simples e universais. Com essa estratégia, Descartes parece indicar a necessidade de um fundamento causal metafísico para as coisas simples e universais, isto é, a necessidade de seu fundamento metafísico ser uma causa eficiente metafísica, pela qual sejam produzidas. Tese que reclama uma teoria da criação.

A busca cartesiana da causalidade das coisas simples e universais começou pelo exame da hipótese de que elas poderiam ter sido causadas pelo sujeito. Porém, por ocasião do argumento do sonho, ficou demonstrado que não poderiam ser causadas por ele, já que sua necessidade escapa ao arbítrio de suas faculdades, de modo que o sujeito não consegue produzi-las nem alterá-las ${ }^{150}$. Só após refutar a causalidade subjetiva, Descartes recorre às instâncias metafísicas, pondo em cena, em primeiro lugar, o argumento do Deus Enganador:

"Faz muito tempo que tenho em meu espírito uma certa opinião, que há um Deus que pode tudo, por quem eu fui criado e produzido tal como sou. Ora, quem poderá me assegurar que esse Deus não tenha feito com que não haja terra alguma, céu algum, corpo extenso algum, figura alguma, grandeza alguma, lugar algum e que, apesar disso, eu possua o sentimento de todas essas coisas e que tudo isso não me pareça existir de forma distinta daquela que eu

\footnotetext{
${ }^{149}$ Cf. M. Gueroult. Descartes selon l'Ordre des Raisons, I, p. 42.

150 "Portanto, quer eu esteja acordado, quer esteja dormindo, dois mais três formarão sempre o número cinco e o quadrado jamais terá mais do que quatro lados; e não parece que coisas tão evidentes possam ser suspeitas de alguma falsidade ou incerteza" (Primeira Meditação, AT IX, 16).
} 
vejo? E, também, como suponho que algumas vezes os outros se enganam até mesmo nas coisas que eles julgam conhecer com maior certeza, pode suceder que Deus tenha desejado que eu me equivoque todas as vezes em que realizo a adição de dois mais três, ou em que eu enumero os lados de um quadrado, ou em que julgo alguma coisa ainda mais fácil, se é que se pode imaginar algo mais fácil do que isso" ${ }^{\text {"151. }}$.

De modo geral, quando se reflete sobre essa passagem, procura-se sempre enfatizar o aspecto enganador e astucioso de um Deus onipotente. Enganador porque nos criou e produziu com esta natureza dotada de ideias de coisas existentes, mas que, na verdade não existem. Enganador, porque desejaria que eu me enganasse sempre que realizasse certas operações como a adição de dois mais três. Eu me enganaria tanto a respeito das coisas gerais, que já se mostraram bastante duvidosas, quanto daquelas simples e universais, nas quais não era possível encontrar nada de duvidoso nem suspeito de falsidade.

Retirando-se, porém, nossa atenção do Deus enganador - que só será refutado posteriormente, embora sofra imediato protesto, quando se evoca a ideia do Deus considerado sumamente bom, de cuja bondade se exclui qualquer indício de malícia -, nota-se aí o delineamento de uma tese ainda mais espantosa, a saber, a de que existe um Deus cuja onipotência interfere na natureza do necessário. Tese que não foi de maneira alguma contestada e que traz para o contexto da dúvida metafísica a polêmica teoria da criação das verdades eternas ${ }^{152}$.

A passagem inicia fazendo menção à opinião alimentada há muito tempo acerca da existência de um Deus onipotente, por quem Descartes afirma ter sido criado e produzido tal como é. A alusão a uma opinião conservada há bastante tempo chama nossa atenção. Segundo Gueroult ${ }^{153}$, trata-se de uma opinião adquirida por ouvir dizer, embora a expressão "ouvir dizer" não apareça no trecho em análise. Embora em outro lugar Descartes admita ter ouvido falar da existência de um Deus criador que pode fazer

\footnotetext{
${ }^{151}$ Idem.

152 Segundo a teoria da livre criação das verdades eternas, a vontade divina é absolutamente livre, indiferente e onipotente. Como nada limita o seu poder, ele pode estabelecer como verdade o que para nós é contraditório e falso. Assim, "a ideia de um engano universal do qual Deus seria o autor não seria uma ficção inteiramente excluída pela natureza de Deus [...] Deus teria sido tão livre para nos enganar quanto foi livre para criar outras verdades que essas que nós reconhecemos" (M. Gueroult. Op. cit. I, p. 42-43). Entretanto, segundo Gueroult, essa consequência retirada da onipotência divina não procede, pois a hipótese do Deus Enganador não se funda sobre a verdadeira natureza da onipotência divina, a qual sendo bem entendida acarreta a supressão daquela (Cf. Idem).

${ }^{153}$ Cf. M. Gueroult. Op. cit. I, p. 45.
} 
tudo o que lhe aprouver ${ }^{154}$, não podemos entender que esta seja uma opinião da qual o filósofo não partilha. Com efeito, pode sem problema algum ser uma referência à teoria da livre criação das verdades eternas, onde aparece a noção autenticamente cartesiana de um Deus onipotente, criador e produtor de todas as coisas, isto é, das essências e das existências, e da natureza humana tal como ela é:

“...nosso espírito é finito e criado de tal natureza que ele pode conceber as coisas que Deus quis que fossem verdadeiramente possíveis, mas não de tal [natureza] que ele possa também conceber como possíveis aquelas que Deus teria podido tornar possíveis, mas que ele quis, todavia, tornar impossíveis" ${ }^{155}$.

As Meditações foram publicadas em 1641. Todavia, em uma carta a Mersenne, datada de 15 de abril de 1630, Descartes tornou pública uma grande descoberta, “capaz de demonstrar as verdades Metafísicas de um modo que é mais evidente que as demonstrações da Geometria"156 e que consistia em sustentar que "as verdades matemáticas, as quais vós [Mersenne] nomeais eternas, foram estabelecidas por Deus e dele dependem inteiramente, tanto quanto o resto das criaturas" ${ }^{\prime 157}$. Passadas algumas semanas, aos 6 de maio do mesmo ano, Descartes escreve novamente a Mersenne, dando as características do Deus que o criou tal como é:

"Deus é uma causa cuja onipotência ultrapassa os limites do entendimento humano, e a necessidade das verdades não excede o nosso conhecimento, elas são alguma coisa de inferior e sujeita a esta potência incompreensivel" ${ }^{, 158}$.

\footnotetext{
${ }^{154}$ Cf. Princípios, art. V. Não temos como desenvolver o problema aqui, mas pode ser uma referência a Ockham, defensor de um voluntarismo divino. Desta ideia de precedência da vontade Descartes se separa, afirmando a absoluta unidade entre suas faculdades sem que uma preceda a outra.

${ }^{155}$ A Mesland, 2 de maio de 1644. AT IV, 118. Escrevendo a Arnauld, Descartes declara: "Digo somente que ele me deu um espírito de tal natureza que eu não poderia conceber uma montanha sem vale, ou que o agregado de um e dois não some três etc. E digo somente que tais coisas implicam contradição em minha concepção" (29 de julho de 1648. AT V, 224).

${ }^{156}$ AT I, 144.

${ }^{157}$ AT I, 145. Já acentuamos que a tese da livre criação não se limita às verdades matemáticas. Agora queremos apenas esclarecer que depender de Deus equivale a ser criado por ele, isto é, produzido por meio de sua vontade, enquanto causa eficiente.

${ }^{158}$ AT, I, 150. Depois da publicação das Meditações, em uma carta a Mesland, datada de 2 de maio de 1644, Descartes explicita ainda mais em que consiste sua natureza criada tal como é: "considerando que nosso espírito é finito e criado de tal natureza, que ele pode conceber como possível as coisas que Deus quis verdadeiramente possíveis, mas não de tal, que possa também conceber como possíveis as que pudesse tornar possíveis, mas que ele entretanto quis tornar impossíveis" (AT IV, 118).
} 
Portanto, havia onze anos que Descartes conservava a opinião sobre um Deus onipotente (Descartes não utiliza o adjetivo enganador nessa passagem), que o criou e o produziu com uma natureza determinada pela necessidade das verdades, tal como ficou evidente com a descoberta das coisas simples e universais. Onze anos sustentando em seu espírito a opinião de que realidades jamais consideradas criadas pela tradição filosófica precedente são, na verdade, criadas. A mesma opinião acusada de marginal e de ter sido posteriormente abandonada não parece agora ter estado sempre presente? Se é muito cedo para afirmá-lo, no entanto, nos exemplos apresentados na passagem em análise, Descartes deixa explícito que entende as coisas gerais e as simples e universais como produzidas pelo Deus onipotente, o qual, aliás, poderia não ter feito nenhuma delas:

\footnotetext{
"Ora, quem poderá me assegurar que esse Deus não tenha feito com que não haja terra alguma, céu algum, corpo extenso algum, figura alguma, grandeza alguma, lugar algum e que, apesar disso, eu possua o sentimento de todas essas coisas e que tudo isso não me pareça existir de forma distinta daquela que eu vejo?"159
}

Ora, se todas essas coisas não existem verdadeiramente, é porque não foram feitas por Deus e seriam ficções do meu espírito. Se, porém, essas coisas verdadeiramente existirem - ainda não se pode afirmá-lo -, só poderão existir enquanto produzidas, quer pelo Deus enganador, quer pelo Deus veraz. Ademais, de que elas poderiam não ter sido feitas, decorre que sua existência e necessidade, de fato, são alguma coisa de inferior e sujeita à onipotência divina, tal como garante a teoria da livre criação das verdades eternas. Portanto, não existem nem são necessárias por si, como se sua necessidade procedesse delas mesmas. Descartes sabe da perplexidade que seu pensamento pode causar. De fato, como alguém pode sustentar que coisas necessárias ou a própria necessidade sejam produzidas, mesmo que por Deus? Não é por acaso que reconhece que muitos preferirão "negar a existência de um Deus tão poderoso a crer que todas as outras coisas são duvidosas" 160 , ou seja, preferirão se apoiar no que carece de fundamento a reconhecer que todas as coisas, inclusive as necessárias e a própria necessidade foram produzidas pela onipotência divina.

\footnotetext{
${ }^{159}$ Primeira Meditação, AT IX, 16.

${ }^{160}$ Idem.
} 
A possibilidade de que eu possa estar enganado aponta imediatamente para a causa da minha origem, que pode permitir ou mesmo querer que eu me engane. Assim, no Deus que tudo pode se encontra intencionalmente a malícia de enganar. Isso acarreta dúvida não apenas quanto ao efeito, ou seja, quanto à existência e verdade das coisas simples e universais e a minha natureza como também à sua causa. Ora, como pode ser Deus e ser enganador, ou seja, ser marcado por uma imperfeição? Ser onipotente e imperfeito, incompleto ou defeituoso? A onipotência já se delineia aqui como uma perfeição divina e se revela inconveniente ao Deus enganador. Um Deus que, embora onipotente, não tem o poder de ser veraz é algo contraditório com a onipotente natureza divina. Com efeito, erro e engano são imperfeições que expõem quão pouco poderoso é aquele que as possui, quer se trate do sujeito, quer da causa à qual imputem sua existência ${ }^{161}$. Portanto, se Deus engana, é imperfeito e, consequentemente, não é onipotente. Ou se assume que os efeitos são imperfeitos, falsos e inexistentes, porque derivam de uma causa imperfeita pouco poderosa, ou que os efeitos permanecem perfeitos, verdadeiros e existentes e se investiga qual será sua causa. Descartes prossegue tentando descobrir a causa.

A primeira alternativa considerada depois da hipótese do Deus enganador é a do Deus bom, que sucumbe ante o argumento da malícia:

"No entanto, pode ser que Deus não tenha querido que eu fosse decepcionado dessa maneira, pois que ele é considerado soberanamente bom. Todavia, se repugna à sua bondade me fazer de tal modo que me engane sempre, do mesmo modo lhe repugnaria permitir que eu me enganasse algumas vezes e, no entanto, não posso negar que ele o permite ${ }^{\text {,162. }}$.

Dessa maneira, Descartes concede seja considerado tudo o que se atribuiu anteriormente a Deus, a saber, que ele seja enganador, ou que deseje ou consinta que eu me engane mais convém a uma fábula.

Rejeitada a existência de um Deus tão poderoso e enganador, é preciso encontrar alguma outra causa responsável por "eu ter chegado ao estado e ao ser que possuo", ou um autor ao qual seja atribuída a minha origem. Mas a quem se poderia atribuir a causa da minha origem, considerando o estado e o ser que possuo, ou seja, um ser que tem

\footnotetext{
${ }^{161}$ Primeira Meditação. AT IX, 17.

${ }^{162}$ Ibidem. AT IX, 16.
} 
ideias de coisas sensíveis e de coisas verdadeiras e existentes independentes da existência de qualquer realidade? Em razão da recusa da hipótese do Deus enganador, recorre-se à hipótese do destino ou da fatalidade, do acaso ou ainda a uma ininterrupta série e relação de $\operatorname{coisas}^{163}$.

Destino ou fatalidade e acaso figuraram tanto na cosmogonia quanto na cosmologia antigas. As mitologias, para Descartes, são tratadas como ficções poéticas ou fábulas ${ }^{164}$. Suas narrativas podem ser instrutivas, mas se limitam ao domínio do imaginário. Rigorosamente falando, o testemunho da mitologia é filosoficamente irrelevante. Sendo assim, a hipótese cartesiana remete-nos à tradição cosmológica pagã, particularmente o epicurismo e o estoicismo, escolas filosóficas do período helenístico, cujos ideais influenciaram o Renascimento, que teve início em fins do século XIII e sobreviveu até meados do XVII, quando foram combatidos e rejeitados ${ }^{165}$.

A ideia de destino ou fatalidade, assim como a da ininterrupta série e relação de coisas, remete-nos diretamente aos estoicos. Segundo eles, o universo é determinado por leis naturais e necessárias estabelecidas pela razão divina imanente. Tudo é como a razão quer que seja e como ela não pode deixar de querer. Portanto, tudo é conforme o destino, isto é, essa "força cósmica e divina, o logos". Destino que é "a ordem e conexão naturais de todas as coisas, nexo causal e necessário ou o nó das causas" ${ }^{166}$ inflexíveis e invioláveis. Não há causa livre e, portanto, tudo é necessário. Todas as coisas estariam numa ininterrupta relação causa-efeito.

O acaso, por sua vez, remontaria ao epicurismo. Para Epicuro e seus seguidores, o mundo é formado por átomos. Movendo-se continuamente desde a eternidade. Graças ao seu próprio peso, eles caem paralelamente no espaço infinito, conectando e desconectando-se uns com os outros, em razão de um desvio "espontâneo, indeterminado, desprovido de causa e, portanto, aleatório"167, ao sabor do acaso, em clara oposição à tese estoica que submetia tudo à implacável necessidade.

\footnotetext{
163 Ibidem. AT IX, 16-17.

164 "Os poetas fingem que os Destinos foram na verdade feitos por Júpiter, e que depois de terem sido uma vez estabelecidos, ele obrigou-se a conservá-los" (Quintas Respostas, AT VII, 380). No Discurso, por sua vez, declara que "as fábulas fazem imaginar como possíveis muitos acontecimentos que não o são” (Discurso do Método, p. 39).

${ }^{165}$ Sabe-se, por exemplo, que Gassendi se intitulava físico epicurista (Cf. Méditations. Ed. Beyssade, nota 1, p. 379). Quanto às influências estoicas à época cartesiana, ver Jacqueline Lagrée. Le Néostö̈cisme, Capítulo I.

${ }_{166}$ Marilena Chaui. Introdução à História da Filosofia, v. 2, p. 145.

${ }^{167}$ Ibidem, p. 101.
} 
Estoicismo e epicurismo pertencem a uma mesma tradição cosmológica. Apesar das divergências e diferenças, foram erguidos sobre o mesmo princípio cosmológico, a saber, o princípio ex nihilo nihil fit, que pressupõe a eternidade da matéria incriada, algo incoerente com a ideia de uma causalidade transcendente e criadora. Materialistas, epicurismo e estoicismo possuem teses inadmissíveis para Descartes, como a defesa dos sentidos e da experiência sensível e a rejeição de uma causa transcendente e criadora do mundo a partir do nada. Embora os estoicos admitissem a causalidade eficiente, como nota Marilena Chaui ${ }^{168}$, não se trata de uma causa eficiente anterior ao mundo, como parece necessária à filosofia cristã e cartesiana.

Está em jogo a questão da causalidade, embora Descartes não empregue o termo causa para se referir àquilo a que atribuem sua origem. Ela deve trazer no bojo a onipotência, quer dizer que deve ser uma causa eficiente, cujo poder crie todas as coisas e, tal como se verá posteriormente, que as crie a partir de nada. Desse poder não dispunham nem os deuses pagãos, nem o destino ou fatalidade, nem o acaso. Falta-lhes a onipotência. Por isso, Descartes diz que "quanto menos poderoso for o autor a quem imputarem minha origem, tanto mais será provável que eu seja de tal maneira imperfeito que me engane sempre"169. Essas instâncias - destino ou fatalidade e acaso - são menos poderosas e imperfeitas, quer consideremos o epicurismo e o estoicismo, quer consideremos a mitologia e, por isso, incapazes de me fazer de tal maneira que eu jamais me engane.

Finalmente, Descartes introduz o artifício do gênio maligno:

"Presumirei, então, que existe não um verdadeiro Deus, que é a suprema fonte da verdade, mas um certo gênio maligno, não menos astucioso e enganador do que poderoso, que dedicou todo o seu empenho em enganar-me. Pensarei que o céu, o ar, a terra, as cores, as figuras, os sons e todas as coisas exteriores que vemos não passam de ilusões e fraudes que ele utiliza para surpreender minha credulidade ${ }^{\Perp 170}$.

A essa altura, o filósofo já sabe que a verdade não pode ter como causa senão a suprema fonte da verdade, que é o verdadeiro Deus. Quais seriam as tais verdades provenientes dele? Até aqui somente as coisas simples e universais, descobertas como

\footnotetext{
${ }^{168}$ Ibidem, p. 141.

${ }^{169}$ Primeira Meditação, AT IX, 17.

${ }^{170}$ Ibidem, AT IX, 17-18.
} 
verdadeiras e existentes, podem legitimamente preencher os requisitos. Mesmo assim, Descartes lança mão do artifício do gênio maligno, caracterizando-o de astucioso, enganador e muito poderoso, mas que de forma alguma se equipara a Deus. Falta-lhe a veracidade característica exclusiva do ser perfeito e, por isso, onipotente.

Como na análise das outras instâncias, explicitamente se manifesta aqui o interesse na causa das coisas simples e universais. Como verdades elas se ligam à suprema fonte de verdade. Descartes tem ressaltado com insistência que a veracidade ou dubitabilidade das coisas simples e universais depende necessariamente de sua causalidade. Em se tentando vinculá-las a qualquer instância inferior não há como ter nenhuma garantia de sua verdade. Curiosamente, o gênio maligno não é apontado como causa das coisas simples e universais. Caso fosse, por se tratar de uma causa maligna, elas não seriam verdadeiras, mas duvidosas. Com efeito, como admitir que coisas provenientes da ação de um ser astucioso e enganador sejam verdadeiras, ainda mais quando já se sabe que a malícia é imperfeição? Como derivar a verdade daquilo que por natureza é enganador?

Descartes afirma que o gênio maligno é tão poderoso quanto astucioso e enganador. Todavia, não parece mais poderoso que as outras instâncias. O Deus enganador apareceu dotado de poder sobre todas as coisas, isto é, ele produz todas as coisas em mim e fora de mim, já que é autor da minha natureza. O destino, a fatalidade e o acaso também são apontados como causa originária da minha natureza. O poder do gênio maligno, por sua vez, parece limitado, conforme diz o trecho citado, ao âmbito exterior ao sujeito. Ademais, o poder que tem não lhe garante perfeição. Aliás, a noção de perfeição vem se mostrando como conceito necessário ao cartesianismo e à refutação das instâncias superiores. Ela faltou tanto ao Deus enganador quanto às instâncias acima mencionadas. Por isso, aquilo que deles procede é, como eles, imperfeito. Falta também agora ao gênio maligno, que, embora poderoso, traz em si a marca da malícia, incompatível com a verdade.

Produtor do mundo exterior, o gênio é caracterizado por Descartes como um artífice, dotado de poder de produzir o mundo, onde o "céu, o ar, a terra, as cores, as figuras, os sons e todas as coisas exteriores que vemos não passam de ilusões e fraudes" ${ }^{\prime 17}$. A produção de ilusões não é habilidade exclusiva desse artífice. Como vimos na apreciação dubitativa do realismo, a imaginação humana também se mostrou

${ }^{171}$ Idem. 
capaz de produzir ilusões e quimeras. Se o poder desse artífice maligno não se estende sobre os pensamentos, muito menos se estenderá sobre as coisas simples e universais, as quais não se fundamentam nem no sujeito nem na realidade material. Muito pelo contrário, são condição das nossas representações e de toda realidade material.

Em face da existência de um gênio maligno produtor do mundo exterior, o grande problema para o sujeito é o da incapacidade de conhecer algo além de si mesmo. É impossível para o sujeito, sob pena de incorrer em erro e falsidade, estabelecer efetivamente a correspondência entre essas coisas e o mundo que tem diante de seus olhos. As coisas simples, por sua vez, podem até ser a condição de algum mundo material, mas não deste que se apresenta a nós, pois este mundo talvez se origine da ação do gênio maligno.

Temos, portanto, de um lado o sujeito, munido de toda a sorte de ideias, cuja origem são as coisas simples e universais. Do outro, está o mundo, caracterizado como o conjunto de ilusões e fraudes produzido pelo gênio maligno e, numa espécie de lugar que não é lugar nenhum, encontram-se as coisas simples e universais, verdadeiras e existentes, condição necessária tanto das nossas representações quanto de um mundo material, pois não se tem como afirmar com verdade que sejam condição necessária deste mundo exterior, antes de se descobrir o Deus veraz. Será mesmo que a ficção do gênio maligno atinge o valor e a validade das coisas simples e universais nelas mesmas ou somente enclausura o sujeito, impossibilitando-o de julgá-las correspondentes à realidade exterior sensível?

Há outro ponto a se observar no artifício do gênio maligno. Ele tem a intenção de enganar e é ela que o torna malicioso. Ora, parece-nos que todo aquele que intencionalmente engana precisa conhecer o que é para produzir o que não é; ao mesmo tempo precisa saber que o que ele produz não é verdadeiro, mas ilusão e, do mesmo modo, que tal ilusão consiste numa distorção do verdadeiro. Neste caso, haveria uma realidade verdadeira sendo fraudada ou distorcida. Se não há um Deus verdadeiro e este gênio está só, somos levados a presumir a existência de uma realidade verdadeira, supostamente conhecida por ele, que, por enquanto, é subsistente por si, incriada e superior a ele. Diante disso, é praticamente impossível resistir a ver nesse gênio uma espécie de demiurgo maligno produzindo seus falsos simulacros, o mundo, sem qualquer correspondência aos verdadeiros paradigmas, aos quais tem acesso. Haveria alguma chance dessas realidades serem as coisas simples e universais, inatingíveis pelo gênio? 
Seja como for, o artífice maligno, conquanto poderoso, não é onipotente, uma vez que não engendra as realidades verdadeiras, cuja existência é necessária à produção de suas ilusões e fraudes. Imperfeito, devido à sua natureza maliciosa, não poderia ser a suprema fonte da verdade. Por conseguinte, as coisas simples e universais, verdadeiras e existentes, não poderiam provir dele.

Qual é o balanço final da apreciação dubitativa do idealismo? Descartes descobre as coisas simples e universais e parte em busca de sua causa. Elas não podem ter como causa o sujeito, pois é constrangido pela força de sua necessidade. O filósofo recorre então às instâncias superiores. Porém, a imperfeição manifesta testemunha contra todas elas, razão pela qual devem ser rejeitadas como verdadeiras causas das coisas simples e universais, verdadeiras e existentes, as quais, aliás, desvinculadas das falsas causas, parecem gozar provisoriamente de um estatuto de existência subsistente por si e em si, quer dizer, são incriadas e incausadas.

Se assim o for, Descartes estaria assumindo para si uma postura filosófica essencialmente platônica. Entretanto, ele não interrompe aí a investigação da causa das coisas simples e universais. É preciso descobrir sua verdadeira causa e, mais especificamente, o gênero de causa pelo qual foram produzidas. Tal descoberta o afasta totalmente de Platão, mas o afasta igualmente da solução medioplatônica aproveitada pelo cristianismo, por meio da qual transpuseram para o interior do intelecto divino os arquétipos eternos, tomados como modelos de todo o criado.

De um lado, a descoberta cartesiana exclui a possibilidade de se admitir a existência das coisas simples e universais como realidades independentes da onipotente vontade criadora, pois assim se estaria assumindo como verdade a existência de um outro eterno que Deus, isto é, de algo incriado, limitador da ação de sua vontade e que o tornaria tão imperfeito e pouco poderoso quanto aquelas instâncias superiores analisadas acima. De outro, rejeita também a solução cristã que considera as essências ou arquétipos ou exemplares ou verdades eternas como realidades dependentes do intelecto divino, mas não de sua vontade, lançando dúvidas sobre a onipotência divina e, mais precisamente, sobre a simplicidade divina, pela qual Descartes entende a absoluta unidade e identidade entre intelecto, vontade e ação em Deus, conforme afirma expressamente a teoria da livre criação das verdades eternas ${ }^{172}$.

\footnotetext{
${ }^{172}$ Escrevendo a Mesland, Descartes declara que a ideia que possuímos de Deus "nos ensina que nele há somente uma única ação, totalmente simples e pura" (2 de maio de 1644. AT. IV, 119). E isto porque "em
} 
Daí a necessidade do filósofo elaborar uma teoria da criação, onde se estabeleça a dependência universal de todas as coisas relativamente ao ser perfeitíssimo e onipotente, suprema fonte de verdade e garantia exclusiva da correspondência entre nosso conhecimento e a realidade exterior. Antes, porém, de expormos a teoria cartesiana da criação, é necessário apresentar a teoria tomasiana da criação. Esta é a mais importante elaboração filosófica da doutrina teológica da criação, aceita e proposta até o presente pela Ortodoxia Cristã como realização da conciliação entre fé e razão, entre Teologia e Filosofia. Nossa intenção, na verdade, é evidenciar o inevitável desmoronamento da teoria tomasiana, em consequência de sua edificação sobre os fundamentos do realismo. Em seu lugar e sobre novos fundamentos, Descartes elabora uma nova e radical teoria da criação, com a qual inaugura a cosmologia moderna, essencialmente filosófica, porque livre da autoridade e do jugo teológicos.

Deus é uma mesma coisa querer, entender e criar, sem que um preceda o outro" (A Mersenne, 27 de maio de 1630. AT I, 152). 


\section{CAPÍTULO TERCEIRO}

\section{TEORIA TOMASIANA DA}

CRIAÇÃO E OBJEÇÕES

CARTESIANAS 


\subsection{Explicação da sentença creatio ex nihilo e distinção radical entre Deus e os demais seres}

“Creatio é a produção de uma coisa na sua substância total, sem se pressupor nada de incriado ou de criado por outrem”, define Tomás ${ }^{173}$. Essa definição rejeita qualquer possibilidade de se admitir tanto a preexistência da matéria como a de qualquer outro ser, seja anjo seja a série de inteligências reivindicada por Avicena por cujo intermédio o mundo seria criado ${ }^{174}$. Quanto ao significado do termo nihil, Tomás esclarece que se trata do não ser, ou seja, o termo nada equivale a nenhum ente ${ }^{175}$. Dito isso, cabe explicitar o sentido de ex nihilo.

Ao contrário do que se poderia pensar, a preposição ex não significa causa material. Por um lado, o sentido preciso dessa preposição pode designar ordem, "como quando se diz que da manhã (ex mane) se faz o meio-dia, isto é, o meio-dia vem depois da manhã" ${ }^{176}$. Dizer, portanto, que as coisas foram feitas do nada "indica a ordem do que é relativamente ao não ser precedente" ${ }^{177}$. Por outro lado, a preposição ex pode também negar a ordem e, nesse sentido, equivale a dizer que "não é feito de alguma coisa" ${ }^{\prime 178}$, negando, portanto, a relação de causa material.

Sendo a criação a produção do ser total sem que se possa pressupor algo de criado ou incriado, segue-se que a ação de criar é exclusiva de Deus:

\footnotetext{
“Criar não pode ser ação própria senão de Deus somente. Pois, é necessário que os efeitos mais universais sejam reduzidos a causas mais universais e primeiras. Ora, dentre todos os efeitos, o mais universal é o ser em si mesmo. Por onde, importa seja ele o efeito próprio da causa primeira e universalíssima que é Deus. E por isso também se diz que nem a inteligência nem a alma nobre dá o ser senão enquanto opera por operação divina. Porém, produzir o ser em absoluto, e não enquanto tal ou tal, pertence à noção de criação. Por onde é manifesto, que a criação é ação peculiar do próprio Deus" ${ }^{\prime 79}$.
}

\footnotetext{
${ }^{173}$ Creatio autem est productio alicuius rei secundum suam totam substantiam, nullo praesupposito quod sit vel increatum vel ab aliquo creatum. (Tomás de Aquino. Summa Theologiae, I, q. 65, a. 3).

${ }^{174}$ Acerca disso, veja-se Julio A. Castello Dubra. Necessidade e Contingência do Efeito da Causa Primeira: uma Comparação entre Tomás de Aquino e Avicena, p. 69-94.

${ }^{175}$ Tomás de Aquino. Suma Teológica, I, q. 45, a.1.

${ }^{176}$ Idem. Grifo nosso.

${ }^{177}$ Idem.

${ }^{178}$ Idem

${ }^{179}$ Ibidem, q. 45, a. 5.
} 
Explicados os termos da sentença, determinemos o domínio do criado. Segundo Tomás, a realidade é constituída de substâncias simples e compostas. Compostas são aquelas que possuem matéria e forma, designando todos os seres materiais. As simples, conhecidas somente a partir do conhecimento das compostas, são desprovidas de matéria. São substâncias simples a alma, a inteligência, o anjo e a causa primeira. Entre as substâncias consideradas simples, alma, inteligência e anjo não gozam de simplicidade absoluta, pois, embora imateriais, são mescladas de potência ${ }^{180}$. A presença da potência denota que sua essência não envolve a existência, sendo-lhes esta acrescentada de fora, do mesmo modo como ocorre às substâncias compostas ${ }^{181}$.

Abordando mais detalhadamente a simplicidade divina na questão três da primeira parte da Suma Teológica, Tomás inicia definindo negativamente o simples como aquilo que exclui a composição corpórea, ou seja, aquilo que não tem corpo, ou mais precisamente, aquilo que exclui a composição de matéria e forma. Há, todavia, uma forma positiva apresentada pelo Doutor Angélico quando diz que simples é o ser cuja essência é idêntica à existência. Trata-se da simplicidade absoluta. Tanto as substâncias compostas, em virtude mesmo dessa composição, quanto as simples, mescladas de potência, não possuem a essência idêntica à existência ${ }^{182}$. A simplicidade absoluta cabe exclusivamente a Deus, pois só nele a essência é idêntica à existência ${ }^{183}$.

Tomás então indaga se as substâncias criadas poderiam ser causadas por princípios inerentes à sua própria natureza ou por algum princípio extrínseco e responde negativamente. Com efeito, elas não poderiam ser causadas por princípios inerentes à sua própria natureza, uma vez que sua essência não envolve a existência, ou seja, a existência não é essencial para a compreensão de sua quididade:

"Tudo quanto não é essencial a respeito da compreensão da quididade constitui algo que procede de fora e que introduz a composição com a essência, visto que nenhuma essência se pode compreender sem os elementos que constituem partes da essência. Ora, toda essência ou quididade pode ser entendida sem que se compreenda qualquer coisa acerca do seu ser ou de sua existência. Com efeito, posso compreender o que sejam o homem e a fênix, ignorando se

\footnotetext{
${ }^{180}$ Tomás de Aquino. O Ente e a Essência, c. 5, 1-3.

${ }^{181}$ Cf. Ibidem, c. 5, 3.

${ }^{182}$ Cf. Tomás de Aquino. Suma Teológica I, q. 3, a. 3.

${ }^{183} \mathrm{Cf}$. Idem.
} 
possuem ou não existência real. É evidente, por conseguinte que a existência difere da essência ou quididade" ${ }^{, 184}$.

Se a existência não decorre da compreensão de sua essência, segue-se que o ser de todas elas é acrescentado de fora. Dessa forma, o ser ou a existência provém de uma causalidade eficiente, extrínseca ou anterior. Do contrário, seria preciso sustentar que "uma coisa seria a causa de si mesma, e uma coisa se produziria a si mesma, o que é impossível"185. Portanto, em toda coisa na qual o ser difere da essência, sua existência necessariamente lhe advém de outra coisa, que é a sua causa. Por conseguinte, toda substância criada é efeito. Entendida como efeito, sua existência é condicionada à existência da causa, pois "o efeito não existe se a causa não existir"

Considerando agora a realidade material cuja existência é atestada pelos sentidos, sabendo que não é causada por princípios inerentes à sua natureza, é forçoso admitir uma causa que a "faça passar da não existência à existência. Ora, tal causa é necessariamente anterior" ${ }^{\prime 187}$. Sendo a causa anterior, ocorre que o criado não existe por si mesmo e, conforme o princípio enunciado por Tomás, tudo o que existe por outro pode ser reduzido ao que existe por si, como à sua causa primeira ${ }^{188}$.

Ao impor uma distinção radical entre o ser absolutamente simples e os demais seres, opera-se uma distinção entre o incriado e o criado. Os demais seres, em virtude da distinção entre essência e existência, só existem porque lhes foi concedido o ato de existir, que só pode ter sido dado por aquele cuja quididade seja seu próprio ser, isto é, o ser absolutamente simples, Deus.

Da simplicidade divina resulta que Deus é o único ser subsistente por si mesmo, ou seja, que é em virtude do seu próprio ser, existindo necessariamente por si, o que significa que não recebeu seu ser de nenhum outro, não foi causado nem produzido por outro. Tal ser existe necessariamente por si, ou seja, "existe sem a possibilidade de não existir, existe necessariamente, visto ser a mesma coisa o existir necessariamente e o ser impossível não existir" ${ }^{\prime 189}$. Resulta que ele só pode ser único e nele essência e existência são idênticas:

\footnotetext{
184 Tomás de Aquino. O Ente e a Essência, c. 5, 3.

${ }^{185}$ Ibidem, c.5, 4.

${ }^{186}$ Tomás de Aquino Suma Teológica, I, q. 44, a.1.

${ }^{187}$ Tomás de Aquino. Compendium Theologiae, c. 6, 9.

188 Tomás de Aquino. O Ente e a Essência, c. 5, 4.

${ }^{189}$ Tomás de Aquino. Compendium Theologiae, c. VI, 8.
} 
"É necessário outrossim que a essência de Deus coincida com o seu ser. Com efeito, em todas aquelas coisas em que a essência difere do ser, necessariamente há uma diferença entre o seu ser e a sua essência, pois é em virtude do seu ser que se diz existir uma coisa, ao passo que é em virtude da sua essência que se diz o que tal coisa é. Daqui que a definição, ao manifestar a essência de uma coisa, demonstra o que ela é. Ora, em Deus não há diferença entre o seu ser e a sua existência, visto não ser Ele um ser composto, mas simples. Nele, portanto, coincidem totalmente a essência e o existir". ${ }^{190}$

Por outro lado, é ele a razão mesma do ser e do existir de todas as coisas, o princípio de todo o ser e a causa absolutamente primeira de todas as coisas que são. Mas se ao contrário, supuséssemos a distinção entre essência e existência em Deus, deveríamos admitir alguns absurdos: o primeiro é o da dependência existencial do ser que existe necessariamente por si de um outro ser e, portanto, que outro ser seria causa eficiente do ser divino. Segundo, o da existência de potência em Deus, pois seu existir viria de uma causa extrínseca, à semelhança das substâncias simples - anjo, inteligência e alma - que, embora não possuam matéria, a presença da potência denota que recebem a existência de outro ser. Deus, por sua vez, é ato puro e não pode estar sujeito a qualquer espécie de mudança ${ }^{191}$. Finalmente, supor a distinção entre essência e existência em Deus equivale a afirmar que o ser supremo não possui em si razão suficiente de sua existência, devendo recebê-la de outrem. E se assim o for, Deus não seria Deus, mas ou uma alma, ou uma inteligência ou um anjo, substâncias simples existentes por outro. Mas em contrário, diz Tomás:

"Deus, por ser o princípio anterior a tudo quanto existe, não tem, fora de si mesmo, nenhuma causa de sua necessidade de existir. Daqui se infere a necessidade de que Deus exista por si mesmo" ${ }^{\text {192 }}$.

Um, portanto, é o ser subsistente por si mesmo, necessariamente existente por si, cuja essência é idêntica à existência. Os demais seres subsistem por outro. Sendo-lhes distinta a essência da existência; não são necessariamente existentes, mas causados por um princípio extrínseco, segundo atesta a experiência sensível, pois "tudo o que pode

\footnotetext{
${ }^{190}$ Ibidem, c. XI, 20. Veja-se também Tomás de Aquino. Suma Contra os Gentios, I, I, c. 22, onde o autor expõe maior riqueza de detalhes os argumentos a favor da identidade entre essência e existência em Deus. ${ }^{191}$ Cf. Tomás de Aquino. Compendium Theologiae, c. IV, IX e X.

${ }^{192}$ Ibidem, c. VI, 9.
} 
existir e não existir necessita de uma causa que o faça passar da não existência para a existência"193. Portanto, do que vimos expondo até o presente, fica claro que as coisas, cujo ser procede de uma causa extrínseca, só podem ter sido produzidas diretamente por Deus, isto é, só podem ter sido criadas, excluindo-se definitivamente a mais remota possibilidade da matéria preexistente ${ }^{194}$.

\subsubsection{A insuficiência ontológica como evidência da criação}

O conceito de insuficiência ontológica expressa o caráter radical da não subsistência por si dos seres, cuja existência é necessariamente causada pelo ser subsistente por si mesmo. Assim sendo, todos os seres, afora Deus, são colocados na condição de efeito, ou seja, sua existência é de tal maneira condicionada à causa que só existe se e somente se a causa existir, ou em termos tomasianos, "não existe se a causa não existir"195.

A experiência sensível atesta de forma incontestável a existência do mundo e comprova ainda que ele não existe por si. Não existindo por si, o mundo é tomado como efeito e, como tal, remete a uma causa que não pode não existir. Assim, a partir da existência do mundo pode-se demonstrar simultaneamente a criação e a existência do Criador. Para tanto, não se deve tomar a via que procede da causa - Deus - em direção aos efeitos - as coisas feitas, explica Tomás. Antes se deve seguir pela via que parte dos efeitos, pois assim se chega com mais segurança à causa primeira:

"Há duas espécies de demonstração. Uma, pela causa, pelo porquê das coisas, a qual se apoia simplesmente nas causas primeiras. Outra, pelo efeito, que é chamada a posteriori, embora se baseie no que é primeiro para nós; quando um efeito nos é mais manifesto que a sua causa, por ele chegamos ao conhecimento desta. Ora, podemos demonstrar a existência da causa própria de um efeito, sempre que este nos é mais conhecido que aquela; porque, dependendo os efeitos da causa, a existência deles supõe, necessariamente, a preexistência desta. Por onde, não nos sendo evidente, a existência de Deus é demonstrável pelos efeitos que conhecemos"196.

\footnotetext{
${ }^{193}$ Tomás de Aquino. Compendium Theologiae, c. VI, 9.

${ }^{194}$ Ibidem, c. XCV, 179-181.

195 Tomás de Aquino. Suma Teológica, I, q. 44, a. 1.

${ }^{196}$ Ibidem, I, q. 2, a. 2.
} 
Com base nisso, ele apresenta as famosas Cinco Vias. Destinadas primeiramente a demonstrar a existência de Deus a posteriori, nelas encontramos as evidências últimas da criação. Coerente com o realismo, tomam como ponto de partida a realidade sensível, cuja insuficiência ontológica, ou seja, uma existência que não provém de si mesma, conduz à causa absolutamente primeira, Deus. As Cinco Vias, portanto, não apenas pretendem demonstrar a existência de Deus, mas de um Deus criador, como também quer demonstrar que o criado é efeito de uma causa divina. Deus é, portanto, colocado acima do demiurgo platônico e do motor imóvel aristotélico, reafirmando e consolidando a tese afirmada desde a origem do cristianismo de que para ser Deus, de fato e de direito, é necessário ser criador.

A primeira via apresentada por Tomás é a do movimento: "a primeira via e a mais manifesta é a procedente do movimento; pois é certo e verificado pelos sentidos, que alguns seres são movidos neste mundo" ${ }^{\text {197 }}$. Assinalemos primeiramente a validade incontestável do testemunho dos sentidos quanto à existência do mundo e do movimento. Movimento, por sua vez, não se refere simplesmente a deslocamento espacial. Segundo explica Tomás, "mover é levar alguma coisa da potência ao ato"198 e, conforme o Compêndio de Teologia, tudo o que uma vez pode existir e outra vez deixa de existir traz em si a marca da mutabilidade e, por isso, necessita de uma causa necessariamente anterior que o faça passar da não existência à existência. Como mover é levar uma coisa da potência ao ato, esse movimento pressupõe um ser anterior que opere tal mudança naquele que muda, porquanto nada pode passar da potência ao ato, do não ser ao ser por si mesmo, senão por meio de uma causa extrínseca ${ }^{199}$. Por outro lado, a coisa em mudança não pode estar em potência e ato sob o mesmo aspecto, pois assim se transgride o princípio de não contradição. Logo, “é impossível uma coisa ser motora e movida ou mover-se a si própria" ${ }^{200}$. Considerando, pois, o princípio de que tudo o que se move é movido por outro, é necessário admitir que aquilo que é movido o seja por outro e assim sucessivamente até se chegar ao primeiro motor, pois os motores segundos não se movem senão pela ação do primeiro, impedindo o movimento de prosseguir ao infinito. O movimento do mundo, portanto, remete a uma causa motora primeira. Porém, a admissão da causa motora primeira não nos autoriza afirmar a criação do mundo, pois, como bem nota Tomás, a criação não pressupõe o movimento:

\footnotetext{
${ }^{197}$ Ibidem, q. 2, a. 3.

198 Idem.

${ }^{199}$ Cf. Tomás de Aquino. Compendium Theologiae, c. VI-VII.

${ }^{200}$ Tomás de Aquino. Suma Teológica, I, q. 2, a. 3.
} 
"Embora o universo tenha começado a existir depois de não ter existido, não é necessário que tal tenha ocorrido através de uma mudança, mas sim mediante criação. Esta não constitui mudança no sentido próprio do termo, senão que constitui uma relação da coisa criada, dependente do Criador no seu ser. Para que haja uma verdadeira mudança, é preciso um algo que uma vez é isto e depois passa a ser aquilo. Ora, tal não ocorre no caso de uma verdadeira criação" ${ }^{201}$.

Assim sendo, a primeira via nos autoriza apenas a admitir que o mundo não tem em si mesmo a causa do seu movimento e, consequentemente, não existe por si mesmo, já que carece de uma causa motora extrínseca e anterior.

Introduzindo a noção de movimento como passagem da potência ao ato, Tomás valeu-se do princípio de que nada passa da potência ao ato por si mesmo, mas somente por meio de uma causa extrínseca. Para tanto, exige-se um agente em ato capaz de operar a suposta mudança. A necessidade do agente é que nos insere na segunda via. Nela, parte-se da análise da natureza da causa eficiente, isto é, aquela que, por sua ação, o efeito é produzido.

Novamente a experiência sensível nos traz as evidências de que nos seres sensíveis há certa ordenação das causas eficientes, isto é, em todas elas "a primeira é causa da média e esta da última, sejam as médias muitas ou uma só" ${ }^{202}$. A ordenação das causas eficientes impossibilita uma coisa de ser causa eficiente de si própria, porque isso equivale a dizer que uma coisa é anterior a si mesma, o que não se pode conceber nem é possível assim ser, pois é "impossível uma coisa produzir a si mesma"203. Poderse-ia, em contrapartida, aventar a hipótese de a série causal proceder ao infinito. Mas em contrário, Tomás adverte que, considerando a ordem das causas eficientes - a primeira causa da média e esta da última - e considerando-se que retirada a causa, o efeito não se produz - pois só existe efeito se a causa existir ${ }^{204}$-, "procedendo ao infinito, não haverá primeira causa, nem efeito último, nem causas eficientes médias, o

\footnotetext{
201 Tomás de Aquino. Compendium Theologiae, c. XCIX, 190.

202 Tomás de Aquino. Suma Teológica, I, q. 2, a. 3.

203 Tomás de Aquino. O Ente e a Essência, c. 5, 4.

${ }^{204}$ Cf. Tomás de Aquino. Suma Teológica, I, q. 44, a. 1.
} 
que evidentemente é falso"205. Donde Tomás conclui a necessária existência de uma causa eficiente absolutamente primeira, que é Deus.

É a introdução da causa eficiente que nos dá uma primeira prova de que o mundo é criado, porque a causalidade eficiente exige a produção de uma coisa por outra anterior $^{206}$. Sendo Deus a causa eficiente primeira é, portanto, a causa produtora do efeito, que é o mundo. Portanto, o mundo é criado. A produção do mundo por Deus dispensa, conforme já apontamos anteriormente, a matéria preexistente, pois não se trata de uma mudança. Assim, a criação é ex nihilo.

A próxima evidência da criação reside na existência de seres contingentes. Ora, a contingência dos seres, por sua vez, parece resultar da existência da causa eficiente, pressuposta à produção de uma coisa. Como efeito, a contingência é definida por Tomás como poder ser e não ser, isto é, como possível, podendo ser gerado e corrompido ${ }^{207}$. Resulta que o contingente não possui em si mesmo a razão de sua existência e, por isso, deve recebê-la de uma causa eficiente, porque "quod non est, non incipit esse nisi per aliquid quod est ${ }^{208}$

Ora, as coisas sensíveis testemunham a contingência; os sentidos comprovam que coisas nascem e se corrompem, ou seja, vêm a ser e deixam de ser. Se as coisas são possíveis, é impossível terem existido sempre, pois é da natureza do possível não ter sido em algum momento e, portanto, houve algum tempo em que nenhuma delas era, quer dizer, houve um momento em que nada existia. Mas se tudo fosse somente possível, ainda hoje nada existiria, pois algo só passa do não ser ao ser através de uma causa extrínseca e anterior, no caso, um ser em ato, uma coisa já existente:

"Se tal fosse verdade, ainda agora nada existiria, pois o que não é só pode começar a existir por uma coisa já existente; ora, nenhum ente existindo, é impossivel que algum comece a existir e, portanto, nada existiria, o que, evidentemente, é falso" ${ }^{\text {209. }}$.

Visto não serem todos os seres somente possíveis, é forçoso que dentre eles haja algum ser necessário. Quanto a este, Tomás ensina que ou será necessário por si ou em virtude de outro ser necessário. Como de costume, é descartada a possibilidade de regressar ao infinito na série de seres necessários, pois, regressando-se ao infinito, não

\footnotetext{
205 Ibidem, q. 2, a. 3.

${ }^{206}$ Cf. Idem. Veja-se também O Ente e a Essência, c. 5, 4.

${ }^{207}$ Cf. Tomás de Aquino. Suma Teológica, I, q. 2, a. 3.

208 “o que não é, só pode começar a existir por meio de uma coisa já existente”. (Ibidem, q. 2, a. 3).

${ }^{209}$ Idem.
} 
haveria de fato nenhum ser necessário. Ademais, rigorosamente falando, necessário é aquilo que existe por si e não em virtude de outro. Donde conclui o Aquinate afirmando ser "forçoso admitir um ser por si necessário, não tendo de fora a causa de sua necessidade, antes, sendo a causa da necessidade dos outros; o que todos chamam Deus" ${ }^{210}$.

As vias seguintes não trarão nenhuma prova da criação e, por isso, decidimos não nos deter em sua análise. Não obstante, elas dão consideráveis descrições da criação e do seu Criador. A contingência da criação não a torna insignificante. Pelo contrário, nos seres contingentes é possível encontrar a perfeição distribuída em graus que vão do mínimo aos mais elevados. De fato, há seres mais e menos perfeitos do que outros. Ora, se há a perfeição em seu grau mínimo, deve haver, e há “algo verdadeiríssimo, ótimo e nobilíssimo e, por conseguinte, maximamente ser"211, que é a causa da perfeição encontrada nos demais seres. Se a criação goza gradualmente da perfeição daquele que é maximamente ser e, por isso, perfeitíssimo, então não procede pensar que o universo seja mau, caótico ou proveniente do caos. Como mostrará a quinta via, observando a ordenação dos seres, especialmente naqueles que não possuem conhecimento, pode-se notar que todos concorrem a um fim:

"É impossível que coisas contrárias e dissonantes estejam sempre, ou muitas vezes, concordes em uma só ordem, a não ser que estejam também sob o governo de alguém pelo qual é dado a todas e a cada uma dirigirem-se a determinado fim ${ }^{, 212}$.

Assim, a existência de ordenação, de lei ou regularidade encontrada na natureza exige uma intenção, a qual, por conseguinte, pressupõe um ente inteligente. A causa eficiente do mundo, portanto, é um ser perfeito e inteligente, um ser pessoal. Consequentemente, o efeito, que é a criação, não é mau nem fruto do acaso ${ }^{213}$.

\subsubsection{Explicação tomasiana da criação}

\footnotetext{
${ }^{210}$ Idem. A precisão da definição de necessidade, da qual resulta a distinção entre o necessário por si e o necessário, cuja necessidade provém de outro será acentuado e radicalizado em Descartes, que continuará considerando Deus a causa da necessidade dos seres necessários, porém como causa eficiente, criadora. Daí o problema: como pode ser necessário e criado, se o criado é necessariamente contingente?

${ }^{211}$ Idem.

212 Tomás de Aquino. Suma Contra os Gentios, I, 13, 27.

${ }^{213} \mathrm{Cf}$. Idem.
} 
Uma das maneiras de se distinguir radicalmente o ser divino dos demais seres passa, como vimos acima, é pela identificação ou distinção entre essência e existência. Deus cuja essência é idêntica à existência é incriado, absolutamente simples, existindo necessariamente por si. Nos demais seres cuja essência se distingue da existência, a essência recebe existência mediante a ação de uma causa extrínseca e anterior e, por isso, são criados. Todos os seres são dotados de essência. No entanto, a essência divina envolve a existência, enquanto em todos os demais seres - materiais e imateriais - a essência não envolve a existência, devendo recebê-la de outrem, no caso da criação, de Deus.

Uma questão se levanta e precisa ser explicada, a saber, a do estatuto de existência dessas essências antes da criação, ou seja, é preciso saber onde e como existem as essências dos seres criados antes de lhes ser conferida a existência. Isto porque se pretende evitar ou superar a concepção de que as essências gozariam de um estatuto existencial semelhante ao das Formas platônicas, ou seja, como realidades incriadas, subsistentes por si, autossuficientes. Já mencionamos que o medioplatonismo transformou as Formas ou Ideias ou os Arquétipos platônicos em pensamentos de Deus, o que foi muito importante para o cristianismo. Retomando a questão, Tomás procura dar-lhe uma solução mais consistente, explicando o modo como ocorre a criação e a função de cada uma das faculdades divinas nesse processo.

Se por um lado a posição tomasiana recusa uma solução platônica para o estatuto das essências, pois equivaleria a sustentar a existência de realidades incriadas, por outro se recusou a considerar as essências - os arquétipos eternos - como realidades criadas, pois não apenas lhes conferiria um caráter contraditório - eterno e criado - como também comprometeria o caráter ex nihilo da criação, que descarta a preexistência de qualquer coisa criada ou incriada anterior à criação, que é a "produção de uma coisa na sua substância total"214 e não parcial.

Ora, há sim uma precedência da essência à existência e, por isso, podemos dizer que de certa maneira as essências precedem a criação. Não, porém, como realidades existentes incriadas ou criadas e exteriores a Deus. São incriadas, mas encontram-se todas em Deus. Os seres preexistem em Deus, segundo Tomás, como um modo de ser inteligível $^{215}$, ou seja, enquanto essências, de modo que "na essência divina estão

\footnotetext{
214 Tomás de Aquino. Suma Teológica I, q. 65, a. 3.

${ }^{215}$ Ibidem, q. 14, a. 2.
} 
compreendidas as espécies das coisas" ${ }^{216}$. Ele afirma que "Todos os efeitos preexistem em Deus, como na causa primeira, preexistem-lhe necessariamente na inteligência; e, portanto, todas as coisas nele existem sob uma forma inteligível"217. Por isso, não se deve fazer distinção entre essas entidades e a essência divina, pois "sua essência mesma é também a espécie inteligível" ${ }^{218}$. As essências, por sua vez, são por ele vinculadas e identificadas com o intelecto divino:

"Nele o intelecto é idêntico ao inteligível. A espécie inteligível não difere da substância do intelecto divino. A espécie inteligível mesma é o intelecto divino",219.

Deus, portanto, tem todo o criado sob forma inteligível no seu intelecto. Nessa condição, as essências permanecem possíveis. Para sair dessa condição e ganhar existência é necessária a intervenção da vontade divina:

"Os efeitos derivam da causa agente enquanto preexistem nela; porque todo agente produz algo que se assemelha a ele. Mas os efeitos preexistem na causa, segundo o modo de ser da mesma. Por isso, assim como o ser de Deus se identifica à sua inteligência, os efeitos preexistem nele como inteligíveis. Portanto, derivarão dele também da mesma maneira. Por consequência, derivarão como objeto da vontade: porque pertence à vontade o impulso de realizar aquilo que foi concebido pela inteligência $" 220$.

A vontade é o princípio agente da criação. Tomás admite também o intelecto divino no processo criador, mas somente "como tendo inclinação para o efeito"221 e não como princípio de ação, ou seja, a inteligência divina é causa das coisas, mas enquanto ciência de aprovação e não como causa eficiente:

\footnotetext{
${ }^{216}$ Idem.

${ }^{217}$ Ibidem, q. 14, a. 2.

${ }^{218}$ Ibidem, q. 14, a. 4.

${ }^{219}$ Idem.

${ }^{220}$ Ibidem, q. 19, a. 4.

${ }^{221}$ Ibidem, q. 14, a. 8.
} 
"A ciência divina é causa com a vontade. Não é necessário que tudo o que Deus sabe, seja, fosse ou haja de ser, mas somente aquilo que ele quer que seja ou que ele permitir ser. Está na ciência de Deus que algo possa ser, mas não que o seja",222.

Segue-se que a criação resulta de uma ação absolutamente livre, ou seja, Deus cria porque quer e, dentre as essências encontradas no seu intelecto, escolhe quais serão atualizadas. $\mathrm{O}$ ato criador mostra-se como uma iniciativa livre e contingente do ser infinito que é, enquanto causa criadora, necessário. Esse ato, porém, não pode ser identificado com o ser necessário da causa criadora, pois equivaleria a dizer que Deus reúne em si mesmo a necessidade e a contingência, as quais se excluem mutuamente, o que constituiria um verdadeiro impasse.

Apesar de a ortodoxia cristã reconhecer o problema, ela parece encontrar uma solução ao distinguir o ato livre do ser necessário de Deus, muito embora não nos seja possível ter uma ideia positiva de como eles sejam distintos. A solução mais satisfatória consiste em admitir esse problema como um verdadeiro mistério inacessível à razão ${ }^{223}$.

A tese tomasiana expressa na afirmação "quod creationem esse, non tantum fides tenet, sed etiam ratio demonstrat" ${ }^{\text {"224 }}$ foi filosoficamente demonstrada em sua teoria da criação. O que antes era apenas uma verdade da fé transformou-se em hipótese filosófica, cuja demonstração racional a consolidou como teoria cosmológica com princípio filosófico próprio, o da creatio ex nihilo. Um acontecimento onde se concretiza o audacioso projeto cristão de conciliar fé e razão, Teologia e Filosofia.

Não obstante, permanece restrita ao âmbito da fé a afirmação de que a criação é um ato pontual, isto é, que antes da criação o mundo não existia, o que é atestado pela Revelação ensinada nas Escrituras, conforme explica Tomás:

“ Os artigos da fé não se podem provar demonstrativamente, porque a fé se refere ao que não se vê, como diz a Escritura ${ }^{225}$. Mas que Deus é o Criador do mundo, de modo que este tenha começado, é artigo de fé; pois dizemos - Creio

\footnotetext{
${ }^{222}$ Tomás de Aquino. Suma Teológica I, q. 14, a. 9.

${ }^{223}$ Cf. F. Van Steenberghen. Dieu Caché, p. 262.

${ }^{224}$ Tomás de Aquino, Scriptum super Sententiis, 2 Sent., d. 1, q. 1, a. 2.

${ }^{225}$ Cf. Carta aos Hebreus, capítulo 11.
} 
em um só Deus etc.[...] Logo, o começo do mundo só se conhece pela revelação. E logo, não pode ser provado demonstrativamente, ${ }^{, 226}$.

De fato, Tomás reconhecia ser essa uma questão de fé, devido à impossibilidade de se demonstrar o começo absoluto do mundo a partir do próprio mundo, pois isso equivaleria a demonstrar o começo do mundo olhando para o próprio mundo, algo de que não se tem base demonstrativa. Alternativamente, talvez se devesse admitir a existência do mundo abeterno, ou seja, existindo desde sempre, ingênito. Ora, Tomás afirma que também essa tese carece de base demonstrativa:

"Nada existe abeterno, exceto Deus; o que não é impossivel de se provar. [...] falando em absoluto, Deus não quer necessariamente senão a si mesmo. Logo, não é necessário Deus querer que o mundo sempre existisse; mas o mundo existe enquanto Deus assim o quiser, porque a existência do mundo depende da vontade de Deus como da sua causa. Logo, não é necessário que o mundo tenha existido sempre; e isso não pode ser provado por demonstração"227.

Embora a tese da existência do mundo desde toda a eternidade não possa também ser demonstrada, nenhum problema haveria em admiti-la, desde que resultasse de um ato eterno pelo qual o mundo fosse produzido e sustentado desde sempre. Se, porém, a razão não pode demonstrar que o mundo teve um começo pontual, nem que ele existe desde sempre, ela demonstra, porém, que o mundo resulta de uma causa suprema. Portanto, em ambos os casos o mundo será criado. Assim, evocando Agostinho, Tomás declara:

\begin{abstract}
"Como diz Agostinho ${ }^{228}$, dupla é a opinião dos filósofos que ensinaram a eternidade do mundo. Pois admitiam que a substância do mundo não provém de Deus; e destes o erro é intolerável e, portanto, por si mesmo refutado. Outros admitiam o mundo eterno, mas diziam que foi feito por Deus. Pois não querem tenha o mundo início no tempo, mas início na sua criação; assim que,
\end{abstract}

\footnotetext{
${ }^{226}$ Tomás de Aquino. Suma Teológica, I, q. 46, a. 2.

${ }^{227}$ Idem, q. 46, a. 1. Tomás já havia notado o que mais tarde será considerado por Kant como antinomia da razão. Este é um impasse com que a razão deve lidar. Kant nota que essa é a primeira antinomia ou conflito interno da razão, no qual ela tanto pode defender uma posição desprovida de contradição em si mesma, como pode defender sua negação com fundamentos válidos (Cf. I. Kant. Crítica da Razão Pura, intodução, VI, p. 30-32).

${ }^{228}$ Cf. Agostinho, A Cidade de Deus, livro XI, (c. IV).
} 
de um modo apenas inteligível, ele sempre seja feito. E, como diz o mesmo autor, encontraram um meio para explicarem o seu pensamento. Pois assim como, dizem, um pé calcando desde toda a eternidade na poeira, sempre estaria por baixo o vestígio, que ninguém duvidaria ter sido causado pelo pé; assim também o mundo sempre existiu, se sempre existiu quem o fez",229.

A insuficiência ontológica do mundo requer uma causalidade eficiente, cuja natureza seja agente e produtora daquilo de que é causa e, sobretudo, requer sua preexistência ao efeito. Ora, a realidade sensível exige uma causa eficiente, pois é impossível ela ser causa eficiente de si mesma, conforme já se mostrou. A causa eficiente, por sua vez, ou é princípio da ação (no caso do começo absoluto do mundo), ou será concomitante ao efeito (no caso da eternidade do mundo). Em ambos os casos, Deus será a causa do mundo:

"Devemos considerar que a causa eficiente, que age por movimento, necessariamente precede no tempo o seu efeito, pois este existe no termo da ação e é necessário seja todo agente princípio da ação. Se a ação, porém, for instantânea e não sucessiva, não é necessário a causa eficiente seja anterior ao que é feito. Por onde dizem que, de ser Deus a causa ativa do mundo não se segue necessariamente seja anterior ao mundo na duração, porque a criação que produziu o mundo não é uma mutação sucessiva",230.

Tomás, portanto, conseguiu consolidar uma autêntica cosmologia cristã portadora de um princípio cosmológico original, a creatio ex nihilo, ao fundamentar filosoficamente a doutrina cristã da criação, agora elevada a teoria filosófica sobre os fundamentos do realismo aristotélico. Ao elevá-la a tal condição, ele pretendia conciliar fé e razão de maneira sólida e duradoura.

Entretanto, ocorreu o contrário. Primeiramente, de doutrina teológica ela passa a uma cosmologia teológico-filosófica. Graças ao caráter racional dado por Tomás, a teoria da criação parece perder seu solo teológico, podendo ser tomada apenas como cosmologia filosófica, independente da autoridade teológica. Em segundo lugar, a teoria cristã da criação foi erigida sobre o fundamento realista aristotélico. Ora, a submissão do realismo à dúvida metódica, onde se expôs a fragilidade dos seus fundamentos, traz

\footnotetext{
${ }^{229}$ Tomás de Aquino. Suma Teológica, I. q 46, a. 2.

${ }^{230}$ Idem.
} 
um impacto direto sobre a teoria tomasiana da criação erguida sobre ele, conforme admoestara o próprio Descartes ao dizer que "a ruína dos fundamentos acarreta necessariamente o desmoronamento do resto do edifício" 231 .

\subsection{Reapreciação dos fundamentos realistas e abandono da cosmologia cristã realista}

Quer consideremos a gnosiologia, quer consideremos a cosmologia de Tomás, nós as percebemos alicerçadas sobre um mesmo fundamento real, qual seja a inquestionável e evidente existência de uma realidade sensível exterior, conhecida diretamente ou através dos sentidos. Acabamos de ver como o Aquinate, partindo sempre das evidências sensíveis apreendidas pela experiência sensível, conseguiu determinar sua origem não sensível. De fato, os próprios fenômenos sensíveis testemunham a insuficiência ontológica dessa realidade, que não existe por si, mas enquanto efeito e, como tal, só existe se sua causa existir, embora esta não seja conhecida com a mesma evidência.

Ora, para se chegar ao conhecimento da verdadeira causa da realidade exterior, Tomás considera como melhor alternativa adotar o procedimento a posteriori, isto é, partindo-se do efeito. Por quê? Pois ele se dá primeiro à experiência sensível e é mais manifesto para nós do que a causa, à qual chegamos por seu intermédio. É dessa maneira que a observação do efeito fornece os elementos necessários à demonstração da criação e da existência de Deus.

Portanto, como não há dúvida acerca do fundamento real, pode-se assegurar que todo conhecimento provém dos sentidos, os quais são constantemente afetados pela realidade sensível exterior, cuja evidente insuficiência ontológica, atestada pela experiência sensível, testemunha sua existência criada e a existência do seu Criador.

Entretanto, a apreciação dubitativa do realismo realizada na Primeira Meditação trouxe à tona sua fragilidade, denunciando inicialmente como crença ou opinião a tese segundo a qual a verdade provém direta ou por intermédio dos sentidos ${ }^{232}$. Os sentidos são falazes e, mesmo que nos enganem poucas vezes, não devemos nos fiar neles. Logo, não posso admitir como verdade o testemunho dos sentidos para dizer o que é o mundo, menos ainda partir deles para determinar a causa imaterial do mundo.

\footnotetext{
${ }^{231}$ Primeira Meditação. AT IX, 14.

${ }^{232}$ Idem.
} 
Ademais, o argumento do sonho mostra o caráter inverídico de nossas sensações, da experiência sensível e da existência da realidade exterior sensível. Com efeito, nos sonhos temos sensações, experimentamos os objetos, percebemo-los existindo fora de nós, mas tudo isso não passa de ficção que não existe efetivamente. Como então reivindicar os sentidos, as sensações, a experiência sensível como fonte verdadeira dos nossos conhecimentos? Se não é evidente a existência de coisas exteriores, não se pode a partir dela nem demonstrar a existência de Deus nem a da criação. Aliás, tais coisas poderiam ser obra de alguma das instâncias superiores mencionadas na Primeira Meditação ${ }^{233}$.

Sendo o objetivo da Primeira Meditação apenas o de levantar dúvidas, a Terceira Meditação começa reconsiderando a via realista para abandoná-la definitivamente. Em vista disso, Descartes parece interessado em descobrir por que, apesar das fortes razões apresentadas na apreciação dubitativa do realismo, é difícil abandonar a crença na autoridade dos sentidos. É preciso descobrir as causas pelas quais sou levado a acreditar na existência de coisas exteriores, distintas de mim, "as quais, por intermédio dos órgãos de meus sentidos ou por qualquer outro meio que seja, enviam-me suas ideias ou imagens e fixam em mim suas semelhanças" ${ }^{234}$, diz o filósofo.

Ele começa classificando os pensamentos em três tipos: as ideias propriamente, que são como imagens das coisas; as vontades ou afecções e os juízos ${ }^{235}$. Tanto as ideias como as afecções da vontade não podem ser consideradas nelas mesmas falsas. $\mathrm{O}$ problema então se refere aos juízos, porque é neles que reside o erro. Com efeito, “o principal erro e o mais ordinário consiste em julgar que as ideias que estão em mim são semelhantes ou conformes às coisas que estão fora de mim" 236 , afirma o filósofo. Conforme diz Gueroult tal erro resulta "da crença de que todo nosso conhecimento nos vem das ideias sensíveis, que são as imagens fiéis das coisas exteriores" ${ }^{237}$, nas quais teriam origem.

Em seguida, Descartes se detém na análise das ideias, classificando-as em três categorias: as inatas que teriam nascido comigo, as fictícias correspondem àquelas produzidas ou inventadas por mim mesmo e as adventícias, estas nem parecem ter

\footnotetext{
${ }^{233}$ Cf. Primeira Meditação. AT IX, 16-18.

234 Terceira Meditação. AT IX, 31.

${ }^{235}$ Ibidem, AT IX, 29.

${ }^{236}$ Terceira Meditação. AT IX, 31.

${ }^{237}$ M. Gueroult. Descartes selon l'Ordre des Raison, I, p. 168.
} 
nascido comigo nem ser produzidas por mim, mas parecem provir de fora ${ }^{238}$. Por enquanto, essa classificação não garante nenhuma certeza a respeitos delas, pois, como bem diz o filósofo, tanto podem todas elas ser estranhas como podem ser inatas ou feitas pelo sujeito. É necessário, diz ele, determinar a verdadeira origem das ideias, especialmente das adventícias, as quais se costuma julgar provenientes dos objetos exteriores, assim como saber quais razões obrigam a julgá-las semelhantes a tais objetos $^{239}$.

Há pelo menos duas: a primeira se refere a uma propensão natural, uma “inclinação irracional que me leva a ver nas coisas exteriores a causa de minha percepção" 240 . Ora, tal inclinação é o oposto do "julgamento certo e premeditado" 241 e contrária à luz natural por meio da qual se conhece a verdade de alguma coisa ${ }^{242}$. Ademais, se tal procede, a cosmologia tomasiana parece perder o estatuto filosófico, uma vez que foi erguida sobre uma inclinação natural, desprovida de fundamento racional. A segunda razão consiste em julgar que as ideias são causadas pelas coisas exteriores mesmas. Com efeito, as ideias sensíveis se formam em $\mathrm{mim}$ independentemente da minha vontade e se semelham aos objetos que elas representam. $\mathrm{O}$ argumento da semelhança entre o objeto e sua ideia, facilmente é refutado ao se levar em conta o fato de inúmeras vezes se notar grande diferença entre ambos. Logo, mesmo que o objeto fosse causa da ideia, disso não resultaria que ela lhe seria semelhante ${ }^{243}$.

Quanto ao aspecto involuntário das ideias, é preciso recordar o argumento do sonho. Nele as imagens se formam involuntariamente e sem a presença dos objetos que elas representam. Descartes contrapõe ainda ao aspecto involuntário das ideias o argumento da faculdade oculta, alegando que talvez haja "alguma capacidade ou poder próprio para produzir essas ideias sem a ajuda de quaisquer coisas exteriores, apesar de ela não me ser ainda conhecida" ${ }^{, 44}$. Como Landim observa, a estratégia cartesiana representa um questionamento da inferência causal, a qual se acha em meio a dificuldades aparentemente incontornáveis ${ }^{245}$. De fato, se a ideia, tomada como efeito, não tem relação com aquilo que por inclinação irracional presumo ser sua causa, sou impedido de estabelecer relações causais entre as ideias e as coisas, uma vez que ignoro

\footnotetext{
${ }^{238}$ Cf. Terceira Meditação. AT IX, 29. Cf. A Mersenne, 16 de junho de 1641. AT III, 383.

${ }^{239}$ Cf. AT IX, 29-30.

${ }^{240}$ M. Gueroult. Op. cit., I, p. 169. Cf. Terceira Meditação. AT IX, 30.

${ }^{241}$ Terceira Meditação. AT IX, 31.

${ }^{242}$ Ibidem. AT IX, 30.

${ }^{243}$ Ibidem. AT IX, 30. Cf. M. Gueroult. Op. cit., I, 169.

244 Terceira Meditação. AT IX, 31.

${ }^{245}$ Cf. R. Landim. Idealismo ou Realismo na Filosofia Primeira de Descartes, p. 147.
} 
as verdadeiras causas. Nessas circunstâncias, sou impedido de sustentar a relação causal entre o mundo e Deus. Portanto, o fundamento real, ou seja, o primado da evidência da existência de uma realidade exterior apreendida direta ou através dos sentidos deve ser abandonado, pois se trata de um falso fundamento, cuja veracidade não pode ser comprovada.

É assim que a apreciação dubitativa do realismo, conjugada com essas novas observações trazidas pela Terceira Meditação, atingem de chofre a teoria tomasiana da criação. Com efeito, todos os elementos demonstrativos da existência de Deus e da criação nos quais se baseia Tomás perdem a eficácia, porque partem de uma coisa cuja existência é tomada como evidente, mas de que, na verdade, não se encontra nenhuma evidência, ou seja, partem do pressuposto de que a realidade sensível exterior existe, quando, na verdade, mantidos os fundamentos realistas, nada garante a existência de tal realidade, nem que seja efeito nem que sua causa seja Deus. Todos os fenômenos constatados pelos sentidos e transformados em provas da existência de Deus e da criação podem ser meras conexões arbitrárias da imaginação. Uma vez que não é possível ter certeza da existência da realidade exterior nem de que ela seja tal como a conhecemos, as provas da existência de Deus e as da criação são invalidadas.

A cosmologia cristã consolidada por Tomás, portanto, evidencia-se alicerçada sobre um frágil fundamento: o pressuposto da incontestável existência da realidade exterior. Esta é algo evidente, enquanto a existência de Deus, causa criadora do mundo, carece de evidência. Além disso, Deus, o supremo fundamento, parece apoiar-se em algo desprovido de fundamento.

Se a existência de Deus necessita de provas, o mundo necessita-o ainda mais. Assim, os princípios fundamentais da prova tomasiana mostram-se frágeis e suas demonstrações sem efeito. Se não há nenhuma garantia segura quanto à existência do mundo, não se pode proceder causalmente à existência de Deus. Ante a possibilidade de o mundo ser uma ilusão ou ficção da imaginação, nada impede que o Deus postulado causa deste mundo ilusório seja também ele uma fábula.

Dessa maneira, malgrado todos os esforços empreendidos por Tomás para demonstrar racionalmente a doutrina da creatio ex nihilo, as ponderações cartesianas permitem ver a ausência de solidez da cosmologia cristã. Primeiro, porque toma como fundamento um pressuposto oriundo de uma inclinação irracional. Depois por estabelecer sobre princípios mal fundamentados, suspeitos e imprecisos seu edifício 
cosmológico. Ora, se a existência do mundo não é evidente, era preciso, inicialmente, proceder com sua demonstração.

O erro de Tomás não foi o de sustentar a tese de que a criação pode ser demonstrada filosoficamente, mas de edificá-la sobre falsos fundamentos. Por isso, Descartes admite a possibilidade de se demonstrar a criação. Do abandono da antiga via, ele inaugura uma nova via erguida sobre novos alicerces. Descartes ressalta que, para se chegar ao conhecimento verdadeiro acerca de qualquer coisa, é preciso primeiramente demonstrar a existência de um Deus. A nova via também se propõe a partir dos efeitos em direção à sua causa, ou seja, trata-se de uma via a posteriori. Ao contrário de Tomás, os efeitos considerados por Descartes jamais poderiam ser as evidências sensíveis, antes parte da análise das ideias, entre as quais encontro a de um Deus veraz e criador de todas as coisas, permitindo demonstrar de uma maneira mais sólida, segundo Descartes, a existência de Deus e a criação. 


\section{SEGUNDA PARTE}

\section{A TEORIA CARTESIANA DA \\ CRIAÇÃO}




\section{CAPÍTULO QUARTO DO DEUS CRIADOR}




\subsection{Rumo à descoberta da ideia de Deus}

Do trajeto percorrido até aqui podemos extrair dois resultados. O primeiro concerne à preparação da teoria cartesiana da criação à medida que explora a motivação cartesiana. O segundo está relacionado aos problemas oriundos da apreciação dubitativa e da objeção cartesiana à teoria tomasiana da criação, cuja solução exige de Descartes uma teoria da criação.

Se existe uma teoria da criação em Descartes, ela é o resultado da apreciação dubitativa dos fundamentos da tradição filosófica, quais sejam o realismo e o idealismo. Submetido por primeiro à apreciação dubitativa, o realismo não conseguiu resistir aos ataques da dúvida. Ora, conforme advertira Descartes, a destruição do fundamento provoca o consequente desmoronamento de todo edifício erguido sobre ele. Nesse caso, o edifício cosmológico cristão, consolidado por Tomás sobre tal fundamento, é diretamente impactado pelas investidas da dúvida.

A queda do realismo levou à descoberta das coisas simples e universais, qualificadas pela Primeira Meditação como verdadeiras e existentes, independentemente da realidade sensível, dos sentidos e do arbítrio, dando início à apreciação dubitativa do idealismo. Apoiando-nos nas reflexões de alguns intérpretes do cartesianismo, distinguimos as coisas simples e universais das ideias e das noções comuns. A nosso ver, a Primeira Meditação as deixava numa situação de realidades existentes por si como os Paradigmas platônicos, principalmente se levarmos em conta que Descartes busca restituir "às ideias sua consistência platônica" "246. A imponência das coisas simples e universais diante da razão força Descartes a radicalizar a dúvida, recorrendo às instâncias superiores como única alternativa de lhes questionar a consistência racional.

Ora, já mencionamos a inexistência de uma teoria idealista da criação. Tal possibilidade estaria imediatamente em contradição com as Escrituras e a Tradição cristã, as quais acentuam constantemente que ao conhecimento de Deus se chega através das criaturas. Sendo assim, qual a importância de se considerar o idealismo no contexto da criação? Ora, em primeiro lugar, a cosmologia cristã é concluída como uma espécie de síntese entre realismo e idealismo. Com efeito, conforme já mostramos, ocorre uma transposição dos arquétipos eternos platônicos para o intelecto divino, operação que,

\footnotetext{
${ }^{246}$ H. Gouhier. La Pensée Métaphysique de Descartes, p. 167.
} 
remontando ao medioplatonismo, foi admitida e lapidada por Agostinho e preservada por Tomás. Tal operação parecia excetuar certas realidades do alcance do poder criador. Não esqueçamos a posição de Suárez acerca das verdades eternas, para quem estas não procederiam de Deus, pois, se assim o fosse, deveriam proceder da vontade divina e, por conseguinte, não seriam necessárias, mas contingentes. Logo, as verdades eternas são colocadas fora do alcance do poder criador.

Diante disso, nossas análises acerca das coisas simples e universais nos permitiram ver o recurso cartesiano às instâncias superiores sob outra perspectiva, qual seja a da submissão do idealismo ao método da dúvida. Dessa maneira, Descartes parece interessado na principal questão em matéria de criação, a saber, a questão da causalidade. A introdução das instâncias superiores e a ligação das coisas simples e universais a elas, a problematização da onipotência e da perfeição dessas instâncias, tudo isso nos convence da preocupação cartesiana em buscar o verdadeiro fundamento causal universal de todas as coisas, pois "nada pode existir em qualquer gênero que seja sem depender de Deus"

Ora, num primeiro momento, as coisas simples e universais surgem indubitáveis em si mesmas, tornando-se duvidosas quando tomadas como efeitos de causas imperfeitas. Isso dá a entender que, sem as falsas causas, elas permaneceriam válidas e verdadeiras. Interrompendo-se aqui o curso da investigação, surgem os seguintes problemas: ou se admitem as coisas simples e universais como realidades verdadeiras e subsistentes por si como os Paradigmas platônicos, tornando problemática a existência de um Deus onipotente e perfeito, ou se aceita vinculá-las de uma vez às instâncias superiores imperfeitas, o que impossibilita o acesso à verdade, dando-se adeus ao projeto cartesiano de fundamentação metafísica da ciência ou à suspensão permanente do nosso juízo. Haveria ainda um terceiro problema resultante da objeção cartesiana à teoria tomasiana da criação, a saber, que as ideias teriam sido causadas pelo próprio sujeito ou por alguma faculdade desconhecida inerente ao sujeito. Tal possibilidade também torna problemática a existência de Deus.

Felizmente, a investigação cartesiana prossegue, obrigando a razão a procurar cuidadosamente o fundamento necessário da existência de todas as coisas, conduzindo à descoberta da existência de Deus, o ser sumamente perfeito e onipotente, verdadeira causa da qual todas as coisas dependem.

\footnotetext{
${ }^{247}$ Discurso do Método, p. 88.
} 
É preciso retornar ao interior da mente e analisar as ideias, particularmente aquelas que me representam coisas. Até o momento não se tem como atestar sua procedência, já que as ideias até então analisadas poderiam ser originadas em mim, através de uma sucessão causal imanente à consciência, ou mesmo sendo o eu a causa formal ou eminente dessa ideia ${ }^{248}$. Por outro lado, cada ideia tem um conteúdo representativo próprio que a difere de outras ideias. Este conteúdo chama-se realidade objetiva, pelo qual Descartes entende "a entidade ou o ser da coisa representada pela ideia, enquanto esta entidade está na ideia; e do mesmo modo, pode-se chamar de perfeição objetiva" ${ }^{, 249}$. Esses conteúdos são, portanto, realidades na consciência ${ }^{250}$, o que permite a Descartes ver neles graus de perfeição e, consequentemente, submetê-los ao princípio de causalidade, a fim de estabelecer a causa da ideia em mim e sua correspondência a seu objeto $^{251}$. Descartes bem sabe que da existência da realidade objetiva das ideias e de que tal realidade tenha uma causa não se segue que "a causa das ideias seja uma realidade formal" ${ }^{252}$. Descartes precisa mostrar que a coisa exibida pela ideia existe formalmente, ou seja, que "ela existe em si mesma" ${ }^{253}$.

Descartes então passa a investigar se haveria especificamente uma ideia cuja realidade objetiva fosse tal que o obrigasse a reconhecer não existir sozinho no mundo, mas existindo com algo que fosse causa daquela ideia ${ }^{254}$, ou seja, uma ideia cuja causa existisse fora do sujeito. Após analisar com cuidado suas ideias e não haver encontrado nenhuma que suprisse as exigências impostas para tal, restou finalmente para ser analisada a ideia de Deus, cujo conteúdo representativo exibe um ser "soberano, eterno, infinito, imutável, onisciente, onipotente e criador universal de todas as coisas que estão fora dele" 255 . Ele não tem dúvida de que tal ideia é a "que certamente tem em si mais realidade objetiva do que aquelas pelas quais as substâncias finitas me são representadas" ${ }^{, 256}$. Agora é preciso indagar se "há ou não alguma coisa nela proveniente

\footnotetext{
${ }^{248}$ R. Landim. Idealismo ou Realismo na Filosofia Primeira de Descartes, p. 148.

${ }^{249}$ Segundas Respostas. AT IX, 124.

${ }^{250}$ Cf. R. Landim. Loc. cit.

${ }^{251}$ Guerout. Descartes selon l'Ordre des Raisons, I, 175-176.

252 Cf. R. Landim. Loc. cit.

${ }^{253}$ H. Gouhier. La Pensée Métaphysique de Descartes, p. 123.

${ }^{254} \mathrm{Cf}$. Terceira Meditação. AT IX, 33.

255 Ibidem. AT IX, 32.

${ }^{256}$ Terceira Meditação. AT IX, 32. Para um aprofundamento do conceito de substância, veja-se: J.-M. Beyssade. A Teoria Cartesiana da Substância. Equivocidade ou Analogia? p. 11-36. A respeito da noção de realidade objetiva: Ethel M. Rocha. O Conceito de Realidade Objetiva na Terceira Meditação de Descartes, p. 203-218; H. Gouhier. Op. cit., 123-126.
} 
de mim mesmo" 257 , ou seja, é preciso determinar a verdadeira causa dessa ideia. Segundo Gueroult, para isso é necessário aplicar dois princípios: o princípio de causalidade, por meio do qual Descartes ascenderá à existência de Deus, e o princípio da correspondência da ideia ao seu ideato, demonstrando que a ideia de Deus em mim é a imagem do ser divino. Assim, não basta apenas "provar que uma coisa é o efeito de uma outra" para se "estabelecer a semelhança entre ambas". Portanto, "a nova via que permaneceu desconhecida ao senso comum e à filosofia tradicional, e na qual Descartes quer se empenhar, consistirá em encontrar um meio de aplicar legitimamente esses dois princípios" ${ }^{, 258}$.

\title{
4.1.1. Da descoberta da ideia à existência do Deus Criador
}

Descartes apresenta novamente a ideia que possui de Deus, mas com uma pequena diferença:

\begin{abstract}
"Pelo nome Deus entendo uma substância infinita, eterna, imutável, independente, onisciente, onipotente, e pela qual eu mesmo e todas as outras coisas que são (se é verdade que há coisas existentes) foram criadas e produzidas" 259 .
\end{abstract}

A diferença está na maneira de apresentar o atributo criador. Antes criador universal de todas as coisas que estão fora dele, agora é apresentado como a substância pela qual eu e todas as coisas que são, foram criadas e produzidas. Tal diferença não é sinal de problema ${ }^{260}$. O Problema mesmo é colocado pelo próprio filósofo considerando

\footnotetext{
${ }^{257}$ Terceira Meditação. AT IX, 35.

${ }^{258}$ M. Guerout. Op. cit. I, 175-176.

${ }^{259}$ Terceira Meditação. AT IX, 35-36. A versão latina da passagem menciona menos atributos e omite o parêntese contido na versão francesa: "Pelo nome de Deus entendo a substância infinita, independente, onisciente, onipotente e pela qual eu mesmo, e as outras coisas existentes, se é que existe outra coisa, são criadas" (AT VII, 45). Isto mais a título de curiosidade do que uma tentativa de promover discussão acerca das versões latina e francesa, pois não há qualquer alteração significativa no conteúdo da ideia do Deus criador.

${ }^{260} \mathrm{Na}$ verdade, Descartes não possui uma lista precisa dos atributos divinos. Nos Princípios, por exemplo, descreve a ideia de Deus como "a de um ente sumamente inteligente, sumamente poderoso e sumamente perfeito" (art. XIV). Logo em seguida (art. XV), menciona apenas o "ente sumamente perfeito". Curley observou essas nuances e apontou a existência de cinco listas em Descartes. Segundo ele, Descartes "considera as listas como um meio insatisfatório de explicar a ideia de Deus" (E. Curley. De Volta ao Argumento Ontológico, p. 67) e isso por dois motivos, explica. Primeiro, sendo Deus infinito, não há como listar os infinitos atributos que possui. Depois, se Deus existe, claro que contém todos os atributos listados e outros que Descartes não se dá ao trabalho de listar (Cf. Idem).
} 
a hipótese de que a ideia de Deus pudesse ser forjada pelo sujeito. Com efeito, conheçome como substância, razão pela qual tenho em mim mesmo a ideia de substância, a partir da qual talvez eu pudesse forjar a ideia de substância infinita ${ }^{261}$.

Todavia, embora eu seja, de fato, uma substância e tenha dela uma ideia, "eu não teria de forma alguma a ideia de uma substância infinita, eu que sou um ser finito, se ela não fosse colocada em mim por alguma substância que fosse verdadeiramente infinita,

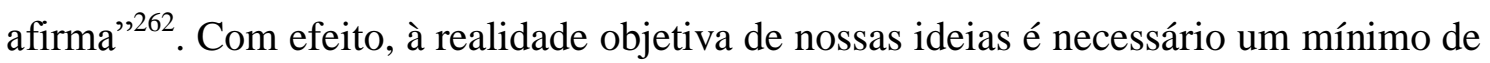
causa eficiente e total, "na qual esta mesma realidade esteja contida não apenas objetivamente, mas formalmente ou eminentemente" ${ }^{263}$. Trata-se de uma ideia cuja realidade objetiva não pode ser causada nem por outra ideia, posto ser o efeito menos perfeito que a causa, nem poderia ser causada pelo sujeito finito, pois o finito não pode ser causa da ideia de infinito. Segundo Descartes, "é um ponto muitíssimo bem conhecido pela luz natural não só que pelo nada nada se faz, nem se produz o que é mais perfeito por aquilo que é menos perfeito" 264 .

E se, em contrapartida, eu não concebo o infinito mediante uma ideia verdadeira? Neste caso, seria muito provável que minha ideia do infinito fosse formada pela negação do finito. Descartes rebate tal possibilidade advertindo para o fato de que há mais realidade na substância infinita que na finita e que existe uma anterioridade da noção de infinito à de finito:

"Pois, como seria possível que eu pudesse conhecer que duvido e desejo, ou seja, que me falta alguma coisa e que eu não sou inteiramente perfeito, se eu não tivesse em mim alguma ideia de um ser mais perfeito que o meu, em comparação ao qual eu conheço os defeitos de minha natureza? ${ }^{265}$

Poderia então acontecer dela ser materialmente falsa, ou seja, uma representação que, na verdade, não representa coisa alguma, como é o caso das ideias de dor, calor, frio, cujas sensações não fornecem nem imagem nem remetem a um objeto exato, sendo desprovidas de clareza e distinção. Porém, a ideia de Deus, afirma Descartes, contém realidade objetiva suficiente para demonstrar ser a mais verdadeira e isenta de qualquer

\footnotetext{
${ }^{261}$ Cf. Terceira Meditação. AT IX, 36.

${ }^{262}$ Ibidem. AT IX, 36.

263 Segundas Respostas. AT, IX, 128.

${ }^{264}$ Princípios, art. XVIII.

${ }^{265}$ Terceira Meditação. AT IX, 36.
} 
sorte de equívoco ou falsidade ${ }^{266}$. Com efeito, ela não me representa qualquer ser, mas um ser supremo, absolutamente perfeito, cuja realidade, ao contrário das outras ideias que encontro em mim, não pode ser causada por mim mesmo. A realidade objetiva da ideia de Deus me obriga, pois, a admitir uma causa distinta e exterior a mim.

Finalmente, ainda é possível indagar se porventura não estaria eu atribuindo a Deus as perfeições contidas potencialmente em mim mesmo. Entretanto, deve-se observar o seguinte: se reconheço a potência em mim, pela qual paulatinamente me aperfeiçoo, então, no mesmo ato, reconheço-me como imperfeito, pois sempre me falta adquirir algo com o qual eu me torne mais perfeito do que era antes ${ }^{267}$. A ideia de Deus, por sua vez, dispensa a potencialidade. A perfeição divina expressa uma plenitude tal que nada lhe falta e, portanto, nada lhe pode ser acrescentado. Concluindo, pois, a primeira prova da existência de Deus pelos efeitos, Descartes afirma: "e enfím eu compreendo muito bem que o ser objetivo de uma ideia não pode ser produzido por um ser que só existe em potência, o qual propriamente falando não é nada, mas somente por um ser formal ou atual"268 ${ }^{\prime 2}$ Eis, a instrutiva explicação dada por Gueroult:

"Percebo em minha consciência uma ideia, a de Deus, cuja realidade objetiva, tendo uma amplitude infinita, ultrapassa infinitamente a realidade formal finita de minha alma. Ela requer necessariamente uma causa que, para ser mais adequada, deve no mínimo possuir uma realidade formal infinita e, por conseguinte, existir fora de mim",269.

Dessa maneira, portanto, Descartes acredita ter conseguido demonstrar a existência necessária de um ser perfeito e infinito, exterior ao sujeito, causa da ideia que tenho dele e, portanto, veraz. Com efeito, "provada a existência de uma realidade infinita, segue-se que essa realidade é veraz" ${ }^{270}$. Note-se que não ocorre nesta primeira prova pelos efeitos a demonstração de que Deus seja causa da minha substância, o que só acontecerá na segunda prova pelos efeitos. Consideramos então demonstrada e, portanto, consolidada a ideia de Deus como verdadeira ideia, a qual não é forjada por mim "nem exibe alguma natureza quimérica, mas uma verdadeira e imutável natureza"

\footnotetext{
${ }^{266}$ Cf. Idem.

${ }^{267}$ Cf. Terceira Meditação. AT IX, 37.

${ }^{268}$ Ibidem. AT IX, 37-38.

${ }^{269}$ M. Gueroult. Op. cit., I, 188-189.

${ }^{270}$ R. Landim. Op. cit., 150.
} 
cuja causa é o próprio Deus, "que não pode não existir"271. Apenas essa prova é necessária para desenvolvermos a noção cartesiana da criação. Da segunda prova pelos efeitos serão extraídas as provas da criação, algo a ser feito posteriormente.

\subsection{O criador universal e a universalidade do ato criador}

\subsubsection{Deus causa eficiente da criação}

Quando se apresenta a ideia de Deus, o atributo criador não aparece isolado, como os outros, mas vem acompanhado de complementos. Os demais atributos surgem aí sem maiores esclarecimentos, enquanto na primeira exposição da ideia de Deus, lembramos novamente, Descartes o apresenta como "criador universal de todas as coisas que estão fora dele" 272 e adiante, expondo a definição do nome Deus, afirma ser a substância infinita pela qual eu e todas as coisas que são foram criados e produzidos ${ }^{273}$. A primeira exposição da ideia de Deus destaca o criador universal e, nesse sentido, conduz-nos à análise da causa da criação. Já a segunda exposição destaca os efeitos, pondo em evidência a universalidade do alcance do ato criador. Em última análise, a tese cartesiana pretende sustentar que se Deus é criador universal, obviamente o alcance do ato criador é também universal, ou seja, não permite exceções, conforme afirma La Croix dizendo que "Deus criou absolutamente tudo" 274.

Como Gouhier, admitimos que "a prova pela ideia de Deus conduz diretamente ao Deus criador" ${ }^{275}$. Entender Deus como criador é entendê-lo como causa eficiente, isto é, aquela por cuja ação um efeito é produzido, segundo a definição oferecida pelos medievais e aceita por Descartes. O Deus cartesiano "se define unicamente pela causa eficiente" 276 , produtora da totalidade da realidade exterior a Deus. Diz Gouhier: "se a ideia de criação é pensada como uma certa causalidade, criar será causar o ser. [...] É desta causalidade que trata a Terceira Meditação"

Para os escolásticos, a causalidade eficiente possui algumas características tais como a anterioridade e a exterioridade ao efeito. Concernente à criação, significa dizer

\footnotetext{
${ }^{271}$ Princípios, art. XV.

272 Terceira Meditação. AT IX, 32.

${ }^{273}$ Cf. Ibidem. AT IX, 35-36.

${ }^{274}$ R. La Croix. Descartes on God's Ability to Do the Logically Impossible, p. 37.

${ }^{275}$ H. Gouhier. La Pensée Métaphisique de Descartes, p. 179.

${ }^{276}$ M. Gueroult. Op. cit., I, 192.

${ }^{277}$ H. Gouhier. Op. cit., p, 180.
} 
que sendo Deus a causa eficiente, ele precede o efeito, cuja existência se dá fora dele. Com isso, estabelece-se a radical distinção entre Deus e a criação, evitando-se assimilar o ser de Deus ao da criação ou conceber a realidade como emanação das coisas do ser divino como, por exemplo, ensinara Plotino, na Antiguidade, e Alfarábi e Avicena, na Idade Média ${ }^{278}$. Por sua vez, a noção cartesiana de causalidade eficiente aplicada a Deus tende a receber um sentido mais rigoroso, designando "eficiente a causa que me criou continuamente [...], quer dizer que me conserva"279.

Podemos usar uma analogia entre Deus e qualquer agente e considerá-los causas eficientes, pois se trata da ação de um agente pela qual se produz um efeito, como o escultor e a escultura, ou à geração dos filhos pelos pais. Nesse sentido, a causa é denominada secundum fieri, ou seja, os efeitos dela dependem exclusivamente quanto à produção ${ }^{280}$. Nos Princípios, porém, Descartes declara que "só Deus pode ser a verdadeira causa de todas as coisas que são ou podem ser" ${ }^{281}$, pela qual entende exatamente a "causa eficiente de todas as coisas" ${ }^{282}$. A causa em questão é designada secundum esse, da qual "os efeitos dependem quanto à subsistência e continuação no ser" ${ }^{283}$. Descartes ilustra com o exemplo da luz em relação ao sol. Este não apenas causa a luz que ele gera como é necessário à sua conservação. Obviamente, trata-se de uma analogia, pois, em última análise, Deus somente é verdadeira causa eficiente "de todas as coisas criadas, não somente no que depende de sua produção, mas mesmo no que concerne à sua conservação ou sua duração no ser" ${ }^{\text {284 }}$, o que se aplica ao sol e à luz que dele emana. Mas por que só Deus pode ser a verdadeira causa? Porque a causa eficiente, na visão cartesiana, requer uma dependência absoluta da coisa em seu ser e em sua existência e à sua conservação, conforme veremos quando tratarmos das provas cartesianas da criação.

Quando expõe a noção do nome Deus, Descartes o considera independente e mais adiante avalia a hipótese da independência do eu: "se eu fosse independente das

\footnotetext{
${ }^{278} \mathrm{O}$ emanacionismo pode ser encontrado em Plotino (Enéadas), em Alfarábi (Idée des Habitants de la Cité Vertueuse) e em Avicena (Liber de Philosophia Prima). A rejeição cartesiana ao emanacionismo aparece em uma de suas cartas, referindo-se à criação das verdades eternas: "pois é certo que ele [Deus] tanto é autor da essência quanto da existência das criaturas: ora esta essência outra coisa não é senão as verdades eternas; as quais eu não concebo emanar de Deus como os raios do sol" (A Mersenne, 27 de maio de 1630. AT I, 152).

${ }_{279}$ Primeiras Respostas. AT IX, 86-87.

${ }^{280}$ Cf. Quintas Respostas. AT IX, 369.

${ }^{281}$ Princípios, art. XXIV.

${ }^{282}$ Ibidem, art. XXVIII.

${ }^{283}$ Quintas Respostas. AT IX, 369.

${ }^{284}$ Idem.
} 
outras coisas... ${ }^{285}$. Independente, como se verá mais tarde, é o que é por si. Nenhuma criatura o é. O ser dependente necessita continuamente do concurso da sua causa para existir. Caso esta deixe de atuar por um instante, o efeito desaparece. Porém, a cessação do efeito não implica o desaparecimento da causa. O efeito não pode vir a ser nem continuar a existir sem o concurso contínuo de sua causa eficiente. Esta noção conjuga a causa secundum esse à da criação contínua. ${ }^{286}$ Ora, visto assim, a causa eficiente cartesiana não parece poder ser ilustrada pela imagem do escultor e de sua escultura nem com a dos filhos gerados pelos pais.

Apesar das nuances em relação ao conceito de causa eficiente, os medievais e Descartes reconhecem na causalidade eficiente divina a dependência no ser, chamada pela metafísica judaico-cristã de criação ${ }^{287}$. Nesse sentido, o conceito de criação em Descartes permanece o mesmo da tradição teológico-filosófica cristã: uma produção ex nihilo, ou seja, um ato pelo qual Deus, enquanto causa eficiente, instituiu todas as coisas a partir de nada.

Ao longo das Meditações há vários indícios de que esta é sua concepção. Por exemplo, na Primeira Meditação, afirma possuir "uma certa opinião de que existe um Deus que pode tudo, por quem fui criado e produzido tal como sou" ${ }^{288}$. Depois, na segunda prova da existência de Deus pelos efeitos, deixa claro que a criação ex nihilo, como já ressaltara Gueroult, é uma expressão da onipotência divina ${ }^{289}$. Nas Terceiras Respostas, dirige-se a Hobbes nestes termos:

"Mas como me servi da ideia de Deus para demonstrar sua existência, e que nesta ideia de Deus está contido um poder tão imenso, que concebemos que repugna (se é verdade que Deus existe) que alguma outra coisa além dele exista sem ter sido criada por ele, segue-se claramente de que sua existência foi demonstrada, que também foi demonstrado que todo esse mundo, isto é, todas as outras coisas diferentes de Deus que existem, foram criadas por ele ${ }^{, 290}$.

\footnotetext{
${ }^{285}$ Terceira Meditação. AT IX, 38.

$286 \mathrm{Na}$ Quarta Meditação, Descartes relembra sua demonstração de "que Deus existe e que minha existência inteiramente depende dele a cada instante" (AT IX, 42).

${ }^{287}$ Cf. H Gouhier. Op. cit., 180.

${ }^{288}$ Primeira Meditação. AT IX, 16

${ }^{289}$ M. Gueroult, Op. cit., I, p. 251.

${ }^{290}$ AT IX, 147.
} 
A criação ou produção de uma substância demanda muito mais poder do que a produção de qualquer acidente ${ }^{291}$. Nesse sentido, Descartes está afinado com a tradição cristã, pois, desde a patrística, reiteradas vezes o pensamento cristão sustentou a tese de que Deus é Deus porque cria ex nihilo ${ }^{292}$. Outra evidência dessa aproximação cartesiana da tradição cristã a respeito da creatio ex nihilo encontra-se numa passagem do $L e$ Monde. Conquanto seja considerada uma fábula, nem por isso a verdade deixa de aparecer nela ${ }^{293}$, adverte. Somos convidados a deixar este mundo e, dando asas à imaginação, penetrar um inteiramente novo:

"entremos aí somente o bastante para que possamos perder de vista todas as criaturas que Deus fez há 5 ou 6 mil anos e, depois de nos determos em algum lugar determinado, suponhamos que Deus crie novamente ao redor de nós, tanta matéria que, de qualquer lado que nossa imaginação possa se estender, ela não perceba mais nenhum lugar que esteja vazio". 294

Se havia de fato algum receio de Descartes em relação aos teólogos, em razão do qual ele designou sua exposição de fábula, talvez o fosse mais pelos desdobramentos da exposição do que pelo conteúdo da passagem citada, porque, para a tradição teológicofilosófica cristã, assim como para Tomás de Aquino, a única coisa que não se poderia afirmar é a existência da matéria independente da ação criadora divina ${ }^{295}$. E Descartes tem razões filosóficas próprias para não afirmar algo do tipo. De fato, a existência de qualquer coisa sem o concurso de Deus anula sua onipotência. Quer-nos parecer que, em razão da lapidação do conceito de criação até à sua consolidação por Tomás, quando se fala em criação não é possível compreendê-la de outro modo que ex nihilo. Por isso, talvez, Descartes não tenha se preocupado em discorrer sobre este conceito. A teoria da criação cartesiana não visa explicar o conceito de criação, mas elaborar a seu respeito uma teoria mais bem fundamentada, coerente com a ideia do verdadeiro Deus. Passemos agora à análise do criador como causa eficiente universal, onde ocorre uma diferença sensível entre a concepção cartesiana e a tradicional.

\footnotetext{
${ }^{291}$ Cf. Terceira Meditação. AT IX, 38-39.

${ }^{292}$ Cf. Tomás de Aquino. Suma Teológica, I q. 45, a. 5.

293 AT XI, 31. Segundo Cottingham, talvez Descartes tivesse decidido designar sua descrição das características físicas gerais do mundo como um novo mundo imaginário, para evitar qualquer espécie de inconveniente com os teólogos (J. Cottingham. Dicionário Descartes, p. 45).

${ }^{294}$ AT XI, 32.

${ }^{295}$ Cf. Tomás de Aquino. Suma Teológica, I, q. 44, a. 2
} 


\subsubsection{Simplicidade divina e universalidade da criação}

Se Deus é criador universal, a ação criadora também deve ser universal. A universalidade da criação resulta da concepção cartesiana acerca da simplicidade divina, a qual aparece na Terceira Meditação como uma das principais perfeições existentes em Deus:

"a unidade, a simplicidade, ou inseparabilidade de todas as coisas que estão em Deus é uma das principais perfeições que concebo haver nele; e certamente a ideia dessa unidade e reunião de todas as perfeições de Deus não foi posta em mim por nenhuma causa da qual eu não tenha também recebido as ideias de todas as outras perfeições" 296 .

Ora, antes de Descartes, Tomás já tinha afirmado a universalidade da criação:

“Criar não pode ser ação própria senão de Deus somente. Pois, é necessário que os efeitos mais universais sejam reduzidos a causas mais universais e primeiras. Ora, dentre todos os efeitos, o mais universal é o ser em si mesmo. Por onde, importa seja ele o efeito próprio da causa primeira e universalíssima que é Deus. ${ }^{297}$.

No entanto, o sentido de criador universal em Descartes difere radicalmente do de Tomás de Aquino. A análise da teoria tomasiana da criação mostrou que Deus é um ser dotado de inteligência e vontade. Graças à operação realizada pelo medioplatonismo, os Arquétipos foram realocados no interior da mente divina, subsistindo nela como espécies inteligíveis, incriadas. Tomás não distingue as espécies inteligíveis do próprio intelecto divino. Segundo ele, em Deus "o intelecto é idêntico ao inteligível. A espécie inteligível não difere da substância do intelecto divino. A espécie inteligível mesma é o próprio intelecto divino" ${ }^{298}$. Por outro lado, a criação recebe sua existência por ação da vontade divina. Assim, Deus olha para os arquétipos encontrados no seu intelecto e decide quais virão a existir, permanecendo os outros apenas possíveis.

\footnotetext{
${ }^{296}$ Terceira Meditação. AT IX, 40.

297 Tomás de Aquino. Suma Teológica, I, q. 45, a. 5.

${ }^{298}$ Ibidem, q. 14, a. 2.
} 
É a vontade divina a responsável imediata por trazer as coisas à existência. O produto de sua vontade é, ao contrário dos arquétipos, uma realidade contingente, finita.

Graças a Ockham, cuja navalha funcionou como uma verdadeira foice, a multidão de arquétipos foi ceifada do intelecto divino, o qual "se vê, agora, esvaziado dos conteúdos que orientavam a ação da vontade divina" ${ }^{299}$. Com o supressão dos arquétipos do intelecto divino, desaparece a precedência do intelecto à vontade de Deus, inaugurando um universo "em que nenhuma necessidade inteligível se interpõe, mesmo em Deus, entre sua essência e suas obras" $" 300$. Toda a criação torna-se radicalmente contingente, quer do ponto de vista de sua existência quer do da sua inteligibilidade. Assim, "não há nada do que é que, se Deus tivesse querido, não teria podido ser de outro modo"301. A ênfase ockhamiana recaindo sobre a vontade divina assume uma postura voluntarista, cujo limite é o princípio de não contradição ${ }^{302}$.

A ideia do contingentismo radical que submete todas as coisas à vontade divina trouxe perplexidade a Suárez. Tratando do estatuto ontológico das verdades eternas entre umas e outras disputationes, ele não hesitou em afirmar que elas

"não são verdadeiras porque conhecidas por Deus, ao contrário são precisamente conhecidas devido à sua própria verdade, de outro modo seria impossível dar qualquer razão pela qual Deus conhecesse necessariamente sua verdade, pois se sua verdade procedesse de Deus mesmo, esta só poderá proceder por intermédio da vontade de Deus, assim não procederia da necessidade, mas da vontade ${ }^{, 303 .}$

Suárez parece concordar com Ockham, pois admite que se algo provém de Deus deve necessariamente provir de sua vontade. Por isso mesmo, recusa-se a submeter todas as coisas à vontade divina e excetua as verdades eternas do seu domínio. Com efeito, tudo quanto procede da vontade divina é necessariamente contingente. Se as verdades eternas procedessem de Deus, elas não seriam necessárias. Em razão disso,

\footnotetext{
${ }^{299}$ M. Chaui. A Nervura do Real, p. 344.

${ }^{300}$ E. Gilson. A Filosofia na Idade Média, p. 813.

${ }^{301}$ Idem.

${ }^{302}$ Segundo M. J. Osler (Divine Will and the Mechanical Philosophy, p. 19), Ockham é um voluntarista. Para ele como para a maioria dos voluntaristas, a vontade divina não é arbitrária. Por isso, a não contradição é considerada uma legítima exceção à absoluta liberdade divina. O mesmo é notado por Chaui quando afirma que "a potência absoluta é o poder absolutamente contingente porque pode tudo quanto não seja contraditório" (Ibidem, p. 411).

${ }^{303}$ Suárez. Disputationes Metaphysicae, DM XXXI, s. 12, § 40.
} 
Suárez parece sustentar a tese da existência autônoma das verdades eternas, uma vez que a veracidade da verdade não procede de Deus, mas da própria verdade, cuja necessidade constrange inclusive o intelecto divino.

Há ou não exceções à universalidade da ação criadora? A resposta de Descartes a essa questão emerge da sua concepção da simplicidade divina.

Concebida como uma das principais perfeições divinas, a simplicidade é apresentada como uma absoluta unidade ou inseparabilidade de todas as coisas existentes em Deus. Tais perfeições compreendem os atributos divinos, entre os quais as faculdades do intelecto e da vontade. Segundo a Correspondência, elas são inseparáveis, porque são idênticas em Deus. Com efeito, “em Deus, querer e conhecer não é senão uma mesma coisa; de modo que no mesmo [ato] em que ele quer alguma coisa, ele a conhece, e somente por isso uma tal coisa é verdadeira" ${ }^{, 304}$. Noutro lugar, Descartes declara que "em Deus é uma mesma coisa querer, entender e criar, sem que um preceda o outro, ne quidem ratione ${ }^{, 305}$. Por fim, escrevendo a Mesland, Descartes deixa claro que a identidade absoluta entre o intelecto e a vontade é uma exigência da própria ideia de Deus. De fato, “a ideia que temos de Deus nos ensina que nele há somente uma única ação, totalmente simples e pura" ${ }^{\text {306 }}$ e, conforme atesta a Terceira Meditação, a ideia da perfeição da simplicidade divina só pode ter como sua causa o próprio Deus $^{307}$.

A noção cartesiana de simplicidade ocasiona uma nova compreensão acerca da liberdade divina, ou seja, em razão mesmo da identidade absoluta entre as faculdades, a liberdade da vontade divina é agora entendida como totalmente livre e indiferente. Que significa isso?

Em primeiro lugar, como o intelecto e a vontade de Deus são idênticos, não pode haver separação entre aquilo que provém do intelecto divino e aquilo que provém da vontade divina, nem hierarquia, submissão ou precedência de uma faculdade à outra, ou seja, nem o intelecto precede a vontade - como querem os intelectualistas - nem a vontade precede o intelecto - como parece decorrer da postura voluntarista.

Depois, a indiferença da vontade divina é incompatível com o livre-arbítrio. $\mathrm{Na}$ visão tomasiana, Deus contempla as essências no seu intelecto, escolhendo entre elas quais serão criadas. Trata-se claramente de uma liberdade que se exerce por escolhas

\footnotetext{
${ }^{304}$ A Mersenne, 6 de maio de 1630. AT I, 149.

305 "nem mesmo na razão", ou seja, logicamente. A Mersenne, 27 de maio de 1630. AT I, 152.

${ }^{306}$ A Mesland, 2 de maio de 1644. AT IV, 119.

${ }^{307}$ Cf. Terceira Meditação. AT IX, 40.
} 
entre alternativas, isto é, uma vontade entendida como livre-arbítrio. Já para Descartes, se nada precede a vontade de Deus, que é idêntica ao intelecto, tornam-se impossíveis alternativas entre as quais Deus exerça sua liberdade, como se agisse motivado por quaisquer exigências de ordem lógica, metafísica, física ou moral, interpostas entre ele e sua ação. Por isso, afirma que "Deus não pode ter sido determinado a fazer que os contraditórios não possam ser conjuntamente, e, por conseguinte, ele poderia fazer o contrário"308. Finalmente, se não há arquétipos e se intelecto vontade e ação em Deus são uma e a mesma coisa, então nada precede o ato criador, consequentemente, Deus precede tudo e, por isso, tudo depende dele: "não há ordem, nem lei, nem razão de bondade e de verdade que não dependa dele; de outra maneira [...], ele não teria sido

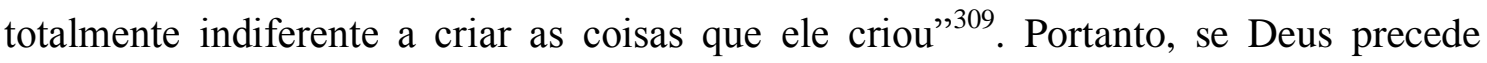
todas as coisas, e se todas as coisas dependem dele, então não há exceção. Sendo assim, tudo procede de Deus, isto é, do seu intelecto e de sua vontade e, portanto, deve ser criado.

Descartes, portanto, rompendo com o antigo modo de explicar a criação, propõe uma alternativa radical, que aparece primeiramente em algumas cartas a Mersenne escritas em 1630, nas quais afirma ser portador da grande descoberta de como “demonstrar as verdades Metafísicas, de um modo que é mais evidente que as demonstrações de Geometria" ${ }^{310}$. Sua descoberta consiste em proclamar Deus o criador não só da existência, mas também das essências, as verdades eternas: "pois é certo que Deus é tanto Autor da essência como da existência das criaturas"311.

Talvez o amigo Mersenne tivesse pensado que, na consideração de Deus como autor tanto das essências quanto da existência das criaturas, não necessariamente estaria implicado que essa autoria fosse mediante criação. Por isso, Mersenne fez questão de pedir explicação a Descartes sobre o gênero de causa pelo qual Deus dispôs as verdades eternas. Descartes prontamente lhe responde:

"Vós me perguntais in quo genere causae Deus disposuit aeternas veritates [em que gênero de causa Deus dispôs as verdades eternas]? Eu vos respondo que in

\footnotetext{
${ }^{308}$ A Mesland, 2 de maio de 1644. AT IV, 118.

${ }^{309}$ Sextas Respostas. AT IX, 235.

${ }^{310}$ A Mersenne, 15 de abril de 1630. AT I, 145.

311 A Mersenne, 27 de maio de 1630. AT I, 152.
} 
eodem genere causae [pelo mesmo gênero de causa] que ele criou todas as coisas, ou seja, ut efficiens \& totalis causa [como causa eficiente e total]",312.

A partir daí, é forçoso concluir que a universalidade do ato criador, no qual está inteiramente envolvida a vontade divina, consiste na tese de que Deus criou todas as coisas - essência e existência - como causa eficiente e total. Dessa forma, Descartes se opõe a Tomás vinculando o domínio do necessário também à vontade divina, a Suárez, submetendo o necessário novamente a Deus e assim evitando a consequência blasfema de afirmar a existência de alguma coisa independente de Deus. De fato, diz Descartes, "se homens entendessem bem o sentido de suas palavras, não poderiam jamais dizer sem blasfêmia que a verdades de qualquer coisa precede o conhecimento que Deus tem dela",313.

Assim, a ideia cartesiana do criador universal requer a compreensão da absoluta dependência do efeito, ou seja, de toda a criação, por meio de uma causalidade eficiente e total, que é a substância infinita ${ }^{314}$. A tese da universalidade da criação é admitida por Descartes, quer se considere a Correspondência quer se considerem as Meditações. A ação criadora se expresse em toda a sua universalidade, porque abrange todas as coisas que estão fora de Deus ${ }^{315}$.

\subsubsection{Das coisas criadas por Deus}

Quando na Terceira Meditação Descartes menciona a ideia do Criador, explicitamente enfatiza a criação como o conjunto das coisas exteriores ao ser sumamente perfeito. A ideia de Deus corresponde a um ser "soberano, eterno, infinito, imutável, onisciente, onipotente e criador universal de todas as coisas que estão fora dele ${ }^{\text {} 316}$. Como a noção de criação restringe-se às coisas exteriores, a questão de Deus como causa sui está fora do escopo da teoria cartesiana da criação. Tudo indica que a maneira pela qual Deus é concebido como causa de si não se confunde com a maneira pela qual ele é causa das demais coisas, o que significa que Deus não é causa criadora de si mesmo. Em razão disso, o presente trabalho não tematizará a causa sui, por

\footnotetext{
312 A Mersenne, 27 de maio de 1630. AT I, 151-152.

313 A Mersenne, 6 de maio de 1630. AT 1, 149.

${ }^{314}$ Cf. Terceira Meditação. AT IX, 35-36.

${ }^{315}$ Cf. Ibidem. AT IX, 32.

${ }^{316}$ Idem.
} 
entender que ela não pertence ao campo da teoria cartesiana da criação. As razões para isso são dadas por Descartes nas Respostas às objeções.

Segundo as Primeiras Respostas, posso entender Deus como causa eficiente de si. Mas a causalidade eficiente, por ser uma causa conservadora, é aquela que cria continuamente. Descartes até reconhece que Deus se conserva, mas não que haja "uma influência positiva da causa eficiente" ${ }^{\natural 17}$, ou seja, que a conservação divina possa ser idêntica à da criação, exigindo criação contínua, a qual requer ser conservado por outro. Na criação o efeito é diferente da causa; mas não só, é também necessariamente imperfeito. Se Deus for causa eficiente de si enquanto causa eficiente criadora, então dever-se-á considerá-lo efeito de si, ao que Descartes rejeita afirmando: "embora eu tenha dito que Deus podia muito bem ser declarado a causa de si mesmo, não se achará que eu o tenha nomeado em algum lugar o efeito de si mesmo" ${ }^{\text {,18 }}$. Se Deus for efeito, então não tem razão suficiente de sua existência e, consequentemente, será imperfeito. Dizer que Deus é causa de si em Descartes é, na verdade, dizer que ele não tem necessidade de causa eficiente ${ }^{319}$.

Portanto, a teoria cartesiana da criação diz respeito às coisas exteriores. São elas, além da ideia de Deus em mim, a coisa pensante, as coisas simples e universais e a coisa extensa. É preciso ressaltar que Deus não pode ser sumamente perfeito se algumas dessas coisas escaparem à onipotência criadora. Essa é uma observação importante, porque, no que concerne à coisa pensante, nota-se que a demonstração da existência do ser perfeitíssimo, enquanto causa de sua ideia em mim, não prova que a existência do sujeito seja causada por Deus. Com efeito, a coisa pensante, resistindo a todas as investidas da dúvida, conseguiu assegurar sua existência antes mesmo de conhecer a existência de Deus. A primeira prova pelos efeitos indica apenas que conheço o ser divino que é a causa de sua ideia em mim.

Pode-se considerar a possibilidade de Deus e eu existirmos como substâncias independentes uma da outra. Admito não ser eu a causa de sua ideia em mim, mas disso não se segue que ele seja a causa da minha existência nem das demais coisas, caso existam. De fato, não apenas descobri minha existência isolada antes de saber se existia um Deus, como também vi que em mim poderia ser encontrada a causa de todas as

\footnotetext{
${ }^{317}$ Primeiras Respostas. AT IX, 87.

${ }^{318}$ Quartas Respostas. AT IX, 187.

${ }^{319}$ Cf. Quartas Respostas. AT IX, 183-184.
} 
ideias que tenho, com exceção da sua. Deus e o eu parecem duas substâncias coexistindo de modo independente.

No entanto, Descartes se pergunta se seria verdadeiramente possível a coisa pensante existir se Deus não existisse ou ser independente dele. A questão é apreciada em duas etapas, nos Princípios. Aí, Descartes ressalta ser "um ponto muito bem conhecido pela luz natural que a coisa que conhece algo mais perfeito do que ela não existe por si (pois ela própria ter-se-ia dado todas as perfeições das quais tem uma ideia dentro de si)"320. Segundo a explicação de Gueroult, a expressão ser por si pode ser entendida positiva e negativamente. Positivamente, dizemos que uma coisa é por si, se ela é causa de si. Negativamente, ser por si significa não possuir causa, ou mais precisamente falando, "não haver tido jamais necessidade de ser criado" ${ }^{321}$.

A segunda etapa é uma consequência da primeira. Como aquele que conhece algo mais perfeito do que ele não existe por si, "nem tampouco, por conseguinte, pode existir por qualquer um que não tenha em si todas aquelas perfeições, isto é, que não seja Deus ${ }^{\prime 322}$. Assim, a demonstração da criação, inerente à segunda prova da existência de Deus pelos efeitos, defenderá e reforçará a tese de que a coisa pensante, de fato, não existe por si, mas é uma substância criada e a criação um atributo exclusivo de Deus, concebido ut efficiens \& totalis causa ${ }^{323}$.

Outra observação se refere às demais coisas mencionadas por Descartes. A existência de um ser sumamente perfeito exclui qualquer necessidade em sua natureza ou imperfeição, o que permite Descartes concluir "que é evidente que ele não pode ser enganador, porque a luz natural nos ensina que a enganação depende necessariamente de algum defeito" ${ }^{\text {324 }}$. Portanto, Deus é veraz.

A demonstração cartesiana da veracidade divina destrói o forte argumento da faculdade oculta ${ }^{325}$. Com efeito, não pode haver uma faculdade em mim sem que Deus não tenha também me dado o conhecimento de sua existência. Do contrário, ele seria enganador $^{326}$. Eliminada a faculdade oculta, desfaz-se, consequentemente o argumento de que as ideias sejam voluntariamente produzidas pelos sujeitos, em vez de se originarem nas coisas que elas representam. Apenas as ideias fictícias são produzidas

\footnotetext{
${ }^{320}$ Princípios, art. XX.

${ }^{321}$ M. Gueroult. Descartes selon l'Ordre des Raisons, I, p. 251.

${ }^{322}$ Princípios, art. XX.

${ }^{323}$ Cf. Terceira Meditação. AT IX, 32 e a carta a Mersenne, 27 de maio de 1630. AT I, 151-152.

${ }^{324}$ Terceira Meditação. AT IX, 41.

${ }^{325}$ Cf. O argumento da faculdade oculta é mencionado explicitamente na Terceira (AT IX, 31) e Sexta (AT IX, 61) Meditações, e de maneira sutil aparece na Quinta Meditação (AT IX 51).

${ }^{326}$ Cf. Sexta Meditação. AT IX, 63.
} 
por mim, quanto às demais, reconheço em mim uma forte inclinação para crer que são causadas por coisas distintas e exteriores a $\mathrm{mim}^{327}$. Sob a garantia da veracidade divina, as ideias em mim corresponderão a coisas, naturezas, formas ou essências diferentes de mim, "que não inventei absolutamente e que não dependem de forma alguma do meu espírito" 328 .

Temos então duas classes de coisas. Primeiro as coisas simples e universais, verdadeiras e existentes, independentes da existência das coisas materiais, às quais acrescentamos as verdades eternas, que são, na verdade, as naturezas eternas e imutáveis. É necessário descobrir se são ou não por si e, caso não sejam por si, determinar qual o gênero de causa de que elas se originam. A outra classe se refere às coisas materiais, às quais é igualmente preciso determinar a verdadeira causa de sua existência, de cuja demonstração se ocupa a Sexta Meditação.

O conjunto das provas cartesianas da criação está localizado na Terceira Meditação, precisamente na segunda prova da existência de Deus pelos efeitos. Apesar de privilegiar a coisa pensante, devido ao fato de que esta pudesse ocupar o lugar de Deus ou coexistir com ele sem, no entanto, dele depender, os mesmos argumentos se prestam a demonstrar a criação das demais coisas acima mencionadas.

\footnotetext{
${ }^{327}$ Cf. Idem.

${ }^{328}$ Quinta Meditação. AT IX, 51.
} 


\section{CAPÍTULO QUINTO}

\section{DEMONSTRAÇÕES CARTESIANAS DA CRIAÇÃO}




\subsection{Criação da coisa pensante}

A demonstração cartesiana da criação consistirá em provar que a coisa pensante, as coisas eternas, necessárias e imutáveis e as materiais foram criadas por Deus. A demonstração começa pela coisa pensante. É preciso decidir se aquilo que possui a ideia de Deus poderia existir independentemente dele, se a coisa pensante existe ou não por si, ou seja, se ela é causa de si ou se é incausada. Por quem, afinal, o sujeito pensante existe? De quem terei eu minha existência? ${ }^{329}$ Para responder a essa questão, Descartes propõe-se a avaliar três hipóteses, a saber, de que talvez minha existência provenha "de mim mesmo, ou de meus pais, ou ainda de quaisquer outras causas menos perfeitas que Deus; pois não se pode imaginar nada de mais perfeito nem mesmo de igual a ele ${ }^{, 330}$.

A primeira hipótese analisa a possibilidade de o sujeito ser por si mesmo e visa, segundo Gueroult, refutar a concepção de que ele causa de si, detendo-se sobre a análise da vontade. A hipótese supõe que eu seja "independente dos outros seres" e "autor do meu ser”, ${ }^{331}$. Todavia, para isto ser assim, não pode me faltar nenhuma perfeição, "pois eu daria a mim mesmo todas aquelas das quais tenho em mim alguma ideia, e assim eu seria Deus" ${ }^{332}$.

Nesse sentido, ser independente equivale a não depender existencialmente de outro ser, não ser causado por outro. Talvez eu consiga me convencer da minha independência, pois minha existência como coisa pensante se deu independentemente da demonstração da existência divina, tendo inclusive lhe precedido. Assim, considerando-me substância pensante, posso julgar-me independente dos outros seres, inclusive de Deus e, portanto, afirmar-me como substância independente. Por conseguinte, sendo eu independente, serei o autor do meu ser. Por autor devemos compreende-se ser criador $^{333}$. Ser autor de si significa existir unicamente pelo poder de sua vontade sem depender de nada mais para isso.

Em contrapartida, como é possível eu ser verdadeiramente independente e autor do meu ser, se me conheço como um ser dotado de paixões e as reconheço em mim mesmo? Como haveria de ser independente aquele que duvida, pois todo aquele que

\footnotetext{
${ }^{329}$ Cf. Terceira Meditação. AT IX, 38.

${ }^{330}$ Idem.

331 Idem.

332 Idem.

${ }^{333}$ Esse significado aparece explicitamente na Correspondência: "pois é certo que ele [Deus] tanto é autor da essência quanto da existência das criaturas: ora esta essência outra coisa não é senão as verdades eternas; as quais eu não concebo emanar de Deus como os raios do sol" (A Mersenne, 27 de maio de 1630. AT I, 152).
} 
duvida carece, necessita, padece a falta da verdade e isso se aplica a todas as paixões. Se duvido, se tenho paixões, sou um ser carente e, portanto, dependente e incompleto, em suma, imperfeito. Minha vontade, conquanto infinita como a de Deus, é agora surpreendida pela finitude de seu poder ${ }^{334}$. Se eu de fato fosse independente, não experimentaria tais necessidades, não teria paixões. Ao contrário, seria perfeito. Faltamme perfeições. Logo, sou dependente, imperfeito e, provavelmente, criado.

Decerto, toda a criação ex nihilo, nota Gueroult, envolve a onipotência ${ }^{335}$, ou seja, um poder absoluto da vontade, atributo exclusivo de um Deus. Ora, como posso ter esse poder absoluto, pelo qual a mim mesmo fiz surgir do nada, e não ser capaz agora nem no passado nem no futuro - de me dotar das perfeições, para cujo ato se requer menos poder? Por isso, pondera Descartes:

"Se eu fosse o autor do meu nascimento e de minha existência, eu não me privaria ao menos das coisas que são mais fáceis de adquirir, a saber, da enorme quantidade de conhecimento de que minha natureza está desprovida; também não me privaria de nenhuma das coisas contidas na ideia que concebo de Deus, pois não há nenhuma que se me afigure de mais difícil obtenção, 336 .

Talvez o sujeito no uso de sua liberdade tivesse julgado e, consequentemente, escolhido o melhor, a saber, não se dar tais perfeições. No entanto, Gueroult explica que para Descartes como para os escolásticos a vontade é um apetite necessário do bem. Assim, a vontade só se dirige ao ser, pois "uma vontade do nada é necessariamente nada de vontade" 337 . Logo, ela se dirige à perfeição e não à imperfeição, escolhe o mais, o melhor. Portanto, ante a constatação da impotência da minha vontade, não posso existir unicamente pelo meu poder. Portanto, sou dependente, imperfeito e criado.

Essa análise traz como consequência o seguinte: é impossível a criação ser obra de um ser imperfeito e, por isso, não posso considerar verdadeiramente onipotente qualquer ser no qual se encontre o menor resquício de imperfeição.

O segundo momento da refutação da hipótese de que o sujeito seja por si, de acordo com Gueroult, ataca a hipótese de que ele seja incausado ${ }^{338}$. A refutação

\footnotetext{
${ }_{334}$ Cf. M. Gueroult. Descartes selon l'Ordre des Raisons, I, p. 251.

${ }^{335} \mathrm{Cf}$. Idem.

${ }^{336}$ Terceira Meditação. AT IX, 38.

${ }^{337}$ M. Gueroult. Loc. cit.

${ }^{338}$ Cf. Ibidem, p. 256.
} 
cartesiana requer dois conceitos peculiares e estreitamente ligados um ao outro: o da descontinuidade do tempo e o da criação contínua:

"todo o tempo da minha vida pode ser dividido em uma infinidade de partes, cada uma das quais não depende de nenhum modo das outras; e assim, de que eu tenha sido um pouco antes, não se segue que eu deva ser agora, exceto se neste momento alguma causa me produza e me crie, por assim dizer, novamente, ou seja, me conserve ${ }^{\text {,339. }}$.

À descoberta do cogito na Segunda Meditação parece subjacente à noção de descontinuidade do tempo. Segundo Descartes, eu sou, eu existo é uma coisa verdadeira e verdadeiramente existente", mas apenas durante o tempo em que penso, pois, caso "eu parasse de pensar, pararia de ser ou de existir" ${ }^{340}$. O tempo, por sua vez, divide-se em uma infinidade de partes, cada uma sendo inteiramente independente das outras. Assim, a existência do cogito está limitada a um instante preciso, sem qualquer vínculo ao passado e sem garantia quanto ao futuro imediato. A independência dos instantes necessita de um elemento articulador que possibilite o sujeito "representar a continuidade temporal chamada de duração". Esta compreende o tempo de permanência de cada coisa na existência, perfaz a continuidade sem, contudo, fazer parte do conjunto dos instantes, os quais, "deixados a si mesmos permaneceriam separados e não haveria o que chamamos de tempo" 341 .

Quando consideramos o tempo de nossa existência, certamente não nos damos conta da independência dos instantes ou da descontinuidade do tempo. Acontece que o tempo é uma quantidade e, como tal, pode ser divisível indefinidamente, por exemplo, como o ano em meses, estes em dias, o dia em horas, estas em minutos, que se dividem em segundos, milésimos, bilionésimos etc. Além de divisível, é descontínuo. Isso quer dizer que "o momento presente não depende em nada do momento precedente" 342 , ou seja, os inúmeros instantes do tempo são absolutamente independentes entre si. O existir de uma coisa em um momento não dá razão suficiente da existência desta coisa no instante seguinte ${ }^{343}$.

\footnotetext{
339 Terceira Meditação. AT IX, 39.

${ }^{340}$ Segunda Meditação. AT IX, 21.

${ }^{341}$ Franklin L. e Silva. Tempo: Experiência e Pensamento, p. 14.

342 Descartes. Discours de la Méthode. Texte et commentaire par E. Gilson (as citações são extraídas do comentário de Gilson, p. 340).

${ }^{343} \mathrm{Cf}$. Idem.
} 
Levando-se em conta a oposição entre instante e duração estabelecida na Regra XII, onde o instante aparece como estado no qual não há lugar para o movimento nem para a duração, parece que o instante é tomado como limite, como nada. Sendo assim, é preciso perguntar de que maneira a existência e a duração emergem a partir da soma dos instantes, isto é, como se dá a impressão de continuidade do tempo. Com efeito, não existe continuidade; o que existe é a recriação direta de cada instante por Deus ${ }^{344}$.

De acordo com Descartes, apenas o ato criador é suficientemente capaz de colocar, num único instante, a coisa pensante e as demais coisas na duração e na existência. E para que eu e todas as coisas - espirituais e materiais - continuemos a existir, em todos os instantes de nossa duração é necessário o "mesmo poder" e "a mesma ação que seria necessária para criar tudo de novo" ${ }^{345}$, caso não existíssemos ainda; ou seja, trata-se do mesmo poder pelo qual todas as coisas vieram à existência quando da creatio ex nihilo. A causalidade eficiente divina é uma causa secundum esse, pela qual se estabelecem os termos da criação contínua, a radical dependência da criatura em relação ao criador. Isso nota Gouhier, quando afirma que "se o ser das criaturas depende de Deus, elas não podem subsistir sem ele um só momento"346.

Analisando a si mesmo, o sujeito constata não se encontrar nele nem o poder de se recriar a cada momento nem aquele de se conservar, o qual não se distingue do poder de criar. Caso o tivesse, certamente teria consciência desse poder. Como não a tem, segue-se que não o possui de modo algum. Logo, eu não sou o autor de minha existência, "mas conheço evidentemente que dependo de algum ser diferente de mim"347. E assim, Descartes considera refutadas as duas possibilidades de o eu ser por si, ou seja, de ele ser causa de si ou ser sem causa, incriado.

O reconhecimento da dependência de um ser distinto conduz a Meditação a averiguar a hipótese de que eu tenha sido causado por outro, o que não significa que este outro seja Deus. De fato, “pode ser também que o ser, do qual dependo, não é aquele que chamo Deus, e que sou produzido pelos meus pais, ou por quaisquer outras causas menos perfeitas que ele" ${ }^{, 348}$.

A hipótese considera duas causas distintas de cuja ação resultaria o efeito, que sou eu: a primeira seriam os meus pais; a segunda as causas menos perfeitas.

\footnotetext{
${ }^{344}$ Cf. Franklin L. e Silva. Loc. cit.

345 Terceira Meditação. AT IX, 39.

${ }^{346}$ H. Gouhier. La Pensée Métaphysique de Descartes, p. 135.

347 Terceira Meditação. AT IX, 39.

348 Idem.
} 
Presumamos, agora, sejam meus pais a causa da minha existência. É até muito plausível, pois se eles não existissem também eu não existiria. Logo, a existência deles seria condição sine qua non da minha.

Há algumas coisas curiosas aí pelas quais passaremos rapidamente. Primeiramente, o argumento referente aos pais aparece somente nas Meditações. Por quê? De acordo com Gueroult, evidentemente Descartes preferiu recorrer ao senso comum $^{349}$, a fim de que, na "longa e sutil argumentação da Terceira Meditação, tornasse a prova pelos efeitos mais acessível" 350 . Todavia, o recurso pedagógico aos pais pode conduzir o leitor acostumado ao esquema das Cinco Vias a pensar que Descartes, fazendo referência a imagens extraídas da realidade sensível, toma como causa uma realidade material existente. Entretanto, a argumentação cartesiana visa demonstrar a minha existência enquanto coisa pensante, imaterial. A realidade sensível ou corpórea não poderia ser evocada como causa da substância espiritual. Ademais, observa Gueroult, no contexto da prova, as causas materiais não têm lugar. Ignora-se sua existência $^{351}$. Dito isso, prossigamos com a refutação da possibilidade de meus pais serem a causa da minha origem.

A primeira razão traz novamente à tona o princípio segundo o qual "deve existir ao menos tanta realidade na causa quanto no seu efeito" ${ }^{\text {352 }}$. Ora, não devemos pensar aqui num ser material, nascido em determinado ano e gerado por fulano e sicrana. Tratase de uma coisa pensante, existente enquanto tal, na qual reside a ideia de Deus, cujo efeito não pode ter sido causado por nenhum outro ser que Deus mesmo. Sendo assim, é necessário que a causa seja igualmente uma coisa pensante e tenha em si a mesma ideia de todas as perfeições atribuídas à natureza divina.

Talvez meus pais sejam coisas pensantes e tenham em si a ideia de Deus. Neste caso, ou eles são por si - causas de si ou incausados - ou por outra coisa, por exemplo, seus pais? Se são por si, são o próprio ser divino e, consequentemente, possuem todas as perfeições atribuídas a Deus. Se não são por si, examina-se, sob as mesmas condições, esta nova causa, até chegar à última causa, "que se comprovará ser Deus. E é muito manifesto que nisto não pode haver progresso ao infinito, visto que não se trata tanto da causa que me produziu outrora, como da que me conserva presentemente" ${ }^{353}$. Aqui, a

\footnotetext{
${ }^{349}$ Cf. M. Gueroult. Op. cit, I, p. 263.

${ }^{350}$ H. Gouhier. Op. cit., p. 136.

${ }^{351}$ Cf. M. Gueroult. Loc. cit.

352 Terceira Meditação. AT IX, 39.

${ }^{353}$ Ibidem. AT IX, 40.
} 
argumentação cartesiana parece reproduzir a Segunda Via de Tomás, a da causalidade, cuja análise das causas segundas dependentes entre si leva à causa primeira incausada, Deus. Respondendo a Caterus, Descartes nega seguir Tomás. Este considera como efeitos as coisas sensíveis, as quais, na perspectiva cartesiana, teriam existência duvidosa e, assim, não nos conduziriam com segurança à existência de Deus, cuja evidência é muito superior à delas ${ }^{354}$. Ora, neste momento da argumentação não existe nenhuma realidade sensível.

Contudo, não é apenas a remissão ao sensível que distingue Descartes de Tomás, e talvez nem seja esta a distinção mais importante. Descartes pretende estabelecer uma distinção entre a geração (a causa que produziu outrora) e a causa conservadora (a verdadeira causa eficiente enunciada nos Princípios $^{355}$ e pressuposta à tese da criação contínua).

Na Terceira Via, por exemplo, está em jogo a geração, a qual é inerente à matéria. Segundo as Escrituras e a Teologia, base da educação católica de Descartes, por uma análise genealógica tanto nos ligamos a Adão quanto a seu pecado. Pecado ocorrido outrora, mas que, misteriosamente, recai sobre toda a espécie humana, graças à geração. Ora, uma vez que a genealogia, fortemente interpretada no contexto religioso (genealogia de Jesus e tantas outras espalhadas pelo Pentateuco), permite interromper a série de causas segundas num indivíduo, Adão, por exemplo, entende-se alguma das razões pelas quais não há progresso ao infinito. E diz-se alguma das razões, porque, por outro lado, Aristóteles defende a eternidade da matéria e Tomás, por sua vez, não exclui esta possibilidade, desde que Deus seja o seu criador desde toda a eternidade, embora seja a Revelação quem dita que o mundo teve um começo e, consequentemente, não existe desde toda eternidade, o que é um Dogma da fé cristã.

Sob esse ponto de vista, a argumentação não se refere à geração, pressuposta na Terceira Via. Muito pelo contrário, a física cartesiana, em coerência com a

\footnotetext{
354 Primeiras Respostas, AT IX, 85. “As causas eficientes, das quais Aristóteles e santo Tomás consideram a sucessão, eles as veem nas coisas sensíveis, in sensibilibus: ora, na nova metafísica, a existência dessas coisas só é conhecida após a de Deus. Porque Descartes não procurou a causa de seu ser enquanto um composto de alma e corpo mas somente enquanto coisa pensante; no âmbito da Terceira Meditação, ele ignora se seu corpo é mais que uma ideia” (H. Gouhier. Op. cit., p. 139).

355 Cf. Princípios, art. XXIV. Talvez eu esteja interpretando a menção "verdadeira causa de todas as coisas que são ou podem ser" como referência exclusiva à causalidade eficiente. Porém, Descartes não parece admitir outro gênero de causa pelo qual as coisas sejam produzidas por Deus que ut efficiens \& totalis causa. Prova disso é o artigo XXVIII da mesma obra, no qual afirma que Deus é "causa eficiente de todas as coisas".
} 
divisibilidade "infinita" da matéria ${ }^{356}$, defende, por conseguinte, o progresso ao infinito. E isto não apenas por convicções físicas, mas também metafísicas. Com efeito, a ideia de Deus me permite conhecê-lo como dotado de uma onipotência absolutamente perfeita, a qual não pode ser contida por quaisquer limites impostos pela razão humana:

"não pode haver progresso ao infinito do ponto de vistas das ideias que estão em mim, porquanto eu me sinto finito [...] Mas quando não ouso negar o progresso ao infinito, é do ponto de vista das obras de Deus, o qual sei que é infinito e, por conseguinte, não me cabe prescrever fim às suas obras" ${ }^{357}$.

Em contrapartida, ouvindo Descartes negar a possibilidade de um progresso ao infinito, objetar-se-lhe-ia que não há qualquer razão que impeça tal progresso, utilizando a concepção do próprio filósofo acerca da matéria. E assim, não é necessário chegar a Deus. Descartes, como que se antecipa à objeção, e adverte que seu argumento não trata de "uma causa que me produziu outrora, mas da que me conserva no presente ${ }^{, 358}$, como coisa pensante. Neste caso, não pode se dar o progresso ao infinito. Mas por que não pode, se o instante, que também é unidade do tempo, pode ser divido ao infinito? $?^{359}$ De fato, o instante pode ser dividido infinitamente, uma vez que "existe uma independência absoluta das diversas partes do tempo da minha vida"360. No entanto, para que eu possa ser conservado em cada átimo do instante, e minha existência perdure, é necessário que eu seja recriado de novo; é necessária uma causa que me conserve a cada instante e da qual eu dependa absolutamente. Em outras palavras, não está em mim o poder de me conservar na existência.

Sob essa ótica, meus pais poderiam mesmo ser considerados condição sine qua non da minha existência? Se eles deixam de existir, eu continuo existindo e vice-versa. Não há nenhuma dependência entre o ser de um e o do outro. Pela via da geração, meus avós seriam muito mais causa minha do que mesmo meus pais, pois sem aqueles estes

\footnotetext{
${ }^{356}$ Cf. Princípios, art. XXVI, cujo título afirma "nunca se deve disputar acerca do infinito, mas tão somente ter por indefinidas as coisas nas quais não notamos quaisquer limites, tais como a extensão do mundo, a divisibilidade das partes da matéria, o número das estrelas etc." Escrevendo a Mesland a respeito da matéria, Descartes também afirma sua divisão ao infinito: "eu acredito que datur revera talis progressus in divisione partium materiae (um tal progresso se dá na divisão das partes da matéria)". (A Mesland, 2 de maio de 1644. AT IV, 112-113). Ver também Le Monde, AT XI, 32-34.

${ }^{357}$ A Clerselier, 23 de abril de 1649. AT V, 355.

${ }^{358}$ Terceira Meditação. AT IX, 40.

${ }^{359}$ Com o que Descartes está de acordo, como ele mesmo afirma a Mesland na carta de 2 de maio de 1644, que a divisão da matéria ao infinito também pode ser concebida no instante (AT IV, 112-113).

${ }^{360}$ M. Gueroult. Descartes selon l'Ordre des Raisons, I, p. 272.
} 
não existiriam. Logo, mais deveria atribuir minha existência aos primeiros do que aos segundos, e aos anteriores, os bisavós, tataravós, etc. $\mathrm{O}$ argumento da geração não nos permite reconhecer com clareza e distinção a verdadeira causa da minha existência. Talvez por isso Descartes admita haver aí muita coisa supostamente verdadeira, a respeito das quais, infelizmente, nunca pôde acreditar ${ }^{361}$. Concedo sejam meus pais princípio do meu nascimento e lhes atribuo alguma disposição à minha matéria. Porém, em relação à verdadeira causa eficiente, se eu não sou por ela conservado, imediatamente cesso de existir. Portanto, embora pareça que a meus pais se deva minha origem, é impossível eles serem a causa que me conserva ou que me tenha feito e produzido como coisa pensante ${ }^{362}$.

Como meus pais não são a causa da minha origem, resta investigar se eu teria sido produzido por causas menos perfeitas que Deus. Em caso afirmativo, provavelmente não foi de uma mesma que recebi as ideias das perfeições de Deus, mas uma dada ideia da perfeição me vem de uma certa causa, outra ideia de outra, quer dizer que provêm de causas separadas, dispersas e não reunidas em uma só perfeição que seja Deus $^{363}$.

Em contrapartida, a ideia de Deus me representa a unidade, simplicidade ou inseparabilidade de todas as coisas que nele existem e é vista por Descartes como uma das principais perfeições divinas. Se as perfeições fossem dispersas, provavelmente a ideia de suma inteligência me viria de uma determinada perfeição existente em algum lugar do Universo, a onipotência viria de uma outra e assim com todas as perfeições.

A unidade me representa um ser infinitamente perfeito. Sendo assim, nele estão reunidas todas as perfeições. A indivisibilidade, por sua vez, impede-me de conceber as perfeições separadas daquele que reúne tais perfeições. Gueroult chega a observar que a unidade e a simplicidade "é menor que sua indivisibilidade numa perfeição infinitamente infinita"364, a qual não provém do eu, cuja finitude já demonstrou sua incapacidade de ser causa da ideia de infinito, mas tem como autor o próprio ser infinitamente perfeito, de quem recebe as ideias das outras perfeições. Com efeito, não poderia eu concebê-las em sua unidade, simplicidade e inseparabilidade, por outro meio que não fosse a própria causa dessas ideias em mim $^{365}$.

\footnotetext{
${ }^{361}$ Cf. Terceira Meditação. AT IX, 40.

${ }^{362}$ Idem.

${ }^{363}$ Cf. Idem.

${ }^{364}$ M. Gueroult. Op. cit., I, p. 262.

${ }^{365}$ Cf. Terceira Meditação. AT IX, 40.
} 
Tal é a ideia que tenho de Deus e tal é o ser causa de minha existência. Uma ideia como essa, diz Descartes, não se adquire através das coisas sensíveis; também não é produto do próprio sujeito finito e impotente. Descartes assim conclui: "não resta mais nada a dizer, senão que, como a ideia de mim mesmo, ela nasceu e foi produzida comigo desde quando fui criado" ${ }^{366}$. Donde Gouhier extrai a seguinte lição: "não é porque eu existo que Deus é requerido como causa do meu ser, mas porque desde meu nascimento eu existo com a ideia de Deus" 367 .

A um só tempo Descartes nos faz conhecer que Deus existe e é o criador do sujeito pensante. Demonstrada a existência de Deus "segue-se que ele é sumamente veraz e doador de toda luz, a ponto de ser absolutamente contraditório que ele nos engane"368, "pois que a luz natural nos ensina que a enganação depende necessariamente de alguma imperfeição"369.

\subsection{Criação das verdades eternas}

Conforme salientamos na primeira parte deste trabalho, o conceito cartesiano de verdades eternas abrange as coisas simples e universais, as naturezas eternas e imutáveis e os possíveis, os quais são cartesianamente classificados em verae e possibiles. Em divergência com a interpretação de Marion, mostramos, no mestrado, que as verdades eternas verae se referem a naturezas, essências ou verdades necessárias, imutáveis e eternas. Concordamos com ele, no entanto, em que as verdades eternas possibiles se referem aos possíveis, ou seja, aos dados especulativos cuja concepção não envolve contradição $^{370}$, desde que não se restrinjam aos dados matemáticos. Conforme ressalta Gleizer, a noção cartesiana de verdade eterna abarca os princípios, as diversas classes de verdades eternas: matemáticas, lógicas, físicas, metafísicas e morais ${ }^{371}$, cuja criação revela a universalidade do alcance do poder criador do ser sumamente perfeito e, ao mesmo tempo, separa a concepção cartesiana de criação da concepção cristã, como se pode notar na Exposição Geométrica das Segundas Respostas, onde se afirma que da

\footnotetext{
${ }^{366}$ Ibidem. AT IX, 41.

${ }^{367}$ H. Gouhier. Op. cit., p. 133.

${ }^{368}$ Princípios, art. XXIX.

369 Terceira Meditação. AT IX, 41.

370 J.-L. Marion. Sur la Théologie Blanche de Descartes, p. 30.

${ }^{371}$ Cf. M. A. Gleizer. Considerações acerca da Doutrina da Livre Criação das Verdades Eternas, p. 184185.
} 
existência do Deus sumamente onipotente segue-se que ele criou "não somente o céu, a terra, etc., mas também todas as coisas que nós conhecemos como possíveis"372.

Na cosmologia cristã, Deus é criador das substâncias simples (alma racional e os anjos) e compostas (os seres compostos de matéria e forma) e nada mais. A concepção cartesiana, ao contrário, ultrapassando essas realidades criadas estende-se ainda aos possíveis, os quais aparecem bem explicados nas palavras de Gouhier:

"No entendimento divino, in mente divina, há, em estilo platônico, Ideias que devem ser chamadas de 'exemplares' e servem de modelos para a criação do mundo, pois as Ideias envolvem tudo o que Deus conhece sem torná-lo real em algum tempo e para os quais santo Tomás reserva a palavra ratio",373.

A tese da criação dos possíveis é incompatível com o pensamento teológicofilosófico cristão, não tanto por envolver questões teológicas, mas por razões lógicas. Com efeito, se os possíveis são os arquétipos eternos, afirmar sua criação é cair em contradição. De fato, como pode algo, ao mesmo tempo e sob o mesmo aspecto, ser eterno e criado, finito, contingente? Descartes, ao contrário, afirma a criação dos possíveis pela onipotência divina. Ora, tanto para a cosmologia cristã quanto em Descartes a criação é posição existencial de uma coisa exterior a Deus. Naquela, porém, sendo o possível uma espécie inteligível, "não difere da substância do intelecto divino. A espécie inteligível mesma é o próprio intelecto divino" 374 e, por isso, não é criado. Em contrapartida, se Descartes concebe o possível como criado, então ele o concebe existindo fora de Deus e, por conseguinte, não há mais possíveis em Deus, pois o criado lhe é necessariamente exterior.

Se, por um lado, a Exposição Geométrica coloca apenas os possíveis sob o alcance da ação criadora, por outro, a chamada teoria da livre criação das verdades eternas submete à criação as verdades eternas verae, criadas pelo mesmo gênero de causa que produz os existentes:

"Pois é certo que ele tanto é autor da essência como da existência das criaturas: ora esta essência outra coisa não é que as verdades eternas, as quais

\footnotetext{
372 Segundas Respostas. AT IX, 131.

${ }^{373}$ H. Gouhier. La pensée Métaphysique de Descartes, p. 288.

${ }^{374}$ Tomás de Aquino. Suma Teológica, I, q. 14, a. 2. E o artigo 5 da mesma questão diz: “todos os efeitos preexistentes em Deus, como na causa primeira, preexistem-lhe necessariamente na inteligência; e, portanto, todas as coisas nele existem sob uma forma inteligível”.
} 
eu não concebo emanar de Deus como os raios do sol, mas eu sei que Deus é o autor de todas as coisas, e que estas verdades eternas são alguma coisa e, por conseguinte, que ele é seu autor ${ }^{\text {,375. }}$

Entre as verdades eternas se inserem as coisas simples e universais e as naturezas ou essências eternas e imutáveis. Entendidas como coisa, elas diferem das ideias, cuja existência se dá exclusivamente no pensamento. Na Primeira Meditação, Descartes afirma claramente que "as imagens de coisas que existem em nossa mente", isto é, as ideias são formadas a partir das coisas simples e universais, "que são verdadeiras e existentes" ${ }^{376}$. Na Quinta Meditação, Descartes observa que embora se possa ter uma infinidade de ideias de certas coisas que talvez existam apenas no pensamento, não se pode deixar de reconhecer que elas não são um puro nada, mas alguma coisa dotada de certa "natureza ou forma, ou essência imutável e eterna" 377 . Para descobrir-lhes a verdadeira causa, Descartes analisa as causas possíveis de sua existência e, por meio de um processo de eliminação, deixa subsistir apenas uma ${ }^{378}$.

Até o momento, a ideia de Deus é a única a ter uma causa exterior ao sujeito, as demais ou seriam voluntariamente causadas por ele ou por alguma faculdade nele oculta. No entanto, a conquista cartesiana da veracidade divina permitirá libertar uma infinidade de ideias do interior do sujeito.

No que concerne às verdades eternas, que nas Meditações aparecem como coisas simples e universais e naturezas eternas e imutáveis, provando a existência do Deus veraz, Descartes exclui-se a hipótese da existência de "alguma faculdade ou poder de produzir ideias sem a ajuda de quaisquer coisas exteriores" 379 que eu desconheço. A veracidade divina, conforme se nota na Sexta Meditação, elimina tal hipótese, alegando que, do contrário, Deus seria enganador, se as ideias tivesse origem em outras causas que as coisas mesmas ${ }^{380}$. Se não existe faculdade oculta, resta a hipótese de que as ideias sejam causadas pela vontade do sujeito. Todavia, foi justamente por reconhecer o caráter involuntário de certas ideias que Descartes recorreu à hipótese da faculdade oculta. Logo, desaparecendo esta, reconheço a existência de ideias que não são causadas por mim. Com efeito, quer desperto quer dormindo, as verdades matemáticas

\footnotetext{
375 A Mersenne, 27 de maio de 1630. AT I, 152.

${ }^{376}$ Primeira Meditação. AT IX, 15.

${ }^{377}$ Cf. Quinta Meditação. AT IX, 51.

${ }^{378}$ M. Gueroult. Descartes selon l'Ordre des Raisons, I, p. 250-251.

${ }^{379}$ Terceira Meditação. AT IX, 31.

${ }^{380}$ Cf. AT IX, 63.
} 
permanecem imutáveis $^{381}$. Ademais, a Quinta Meditação referindo-se às naturezas eternas e imutáveis afirma que elas não são criadas ou inventadas por mim, nem tampouco dependem do meu espírito ${ }^{382}$. Com efeito, a necessidade, eternidade e imutabilidade nelas encontrada não é algo imposto pelo intelecto finito ${ }^{383}$, cuja natureza é determinada pelo princípio de não contradição ${ }^{384}$. A vontade humana, conquanto infinita, possui um poder finito e, por conseguinte, incapaz de alterar essas coisas, naturezas e verdades. A hipótese da causa subjetiva está definitivamente descartada.

O passo agora, considerando a existência dessas coisas necessárias, eternas e imutáveis, é investigar se também elas têm uma causa ou se são absolutamente independentes. A fim de sabê-lo, deve-se determinar se tais coisas seriam por si, isto é, se seriam causa de si ou incausadas. Na verdade, o que se pretende determinar é se elas poderiam ser causadas por outra coisa que não seja Deus.

Ora, a hipótese de que elas sejam causa eficiente de si é facilmente eliminada, pois para isto elas precisariam ser dotadas de vontade, ao menos é o que aparece na exposição cartesiana e foi base do argumento contrário à tese da coisa pensante como causa de si. Disso, porém, não resulta ainda que sua causa seja Deus, porque poderiam ser incausadas e, por conseguinte, absolutamente independentes. Todavia, é mesmo possível existir alguma coisa cuja natureza ou essência seja tal "que não tenha necessidade de causa eficiente para ser ou existir"? ${ }^{385}$ Tal é a questão levantada nas Quartas Respostas.

A admissão dessa possibilidade implica necessariamente no esvaziamento da divindade e da onipotência do ser infinitamente perfeito: “É, com efeito, falar de Deus como um Júpiter ou Saturno, e sujeitá-lo ao Estige e aos Destinos, dizer que essas verdades são independentes dele" ${ }^{\natural 86}$. Ademais, atendo-nos ao caso das coisas simples e universais concebidas como condição de possibilidade da existência do mundo material elas, do mesmo modo que as verdades eternas, precederiam o ato criador e impor-seiam a Deus, o qual, reduzido à mesma condição do demiurgo platônico, criaria o mundo em conformidade com os arquétipos eternos, aos quais tanto a ação divina quanto sua obra estariam condicionadas. Por isso, Descartes adverte que "se os homens

\footnotetext{
${ }^{381}$ Cf. Primeira Meditação. AT IX, 16

${ }^{382}$ Cf. AT IX, 51.

${ }^{383}$ Cf. Quinta Meditação. AT IX, 53

${ }^{384}$ Cf. A Mesland, 2 de maio de 1644. AT IV, 118; A Arnauld, 29 de julho de 1648. AT V, 224.

${ }^{385}$ Quartas Respostas. AT IX, 186.

386 A Mersenne, 15 de abril de 1630.
} 
entendessem bem o sentido de suas palavras, não poderiam jamais dizer sem blasfêmia que a verdade de qualquer coisa precede o conhecimento que Deus tem dela"387.

A existência de coisas independentes de Deus é incompatível com a verdadeira ideia do ser infinitamente perfeito. De fato, como pode ser Deus o ser que contém em si todas as perfeições, entre as quais a onipotência, quando haveria uma classe de seres independentes dele, ou seja, que não o tem como sua causa? De que maneira pode Deus ter tido o poder para retirar a substância do nada e, em contrapartida, ser desprovido de poder para criar essas entidades?

Se, portanto, há alguma coisa cujo ser prescindiu da onipotência, então Deus, ao contrário do que se pensava, não é onipotente e, consequentemente, não é Deus. Necessariamente Deus deverá receber seu ser de outrem, que será a causa eficiente de sua existência, o que não apenas seria um absurdo. Em contrapartida, Descartes afirma:

"Deus é uma causa cuja potência ultrapassa os limites do entendimento humano, e a necessidade das verdades não excede o nosso conhecimento, elas são alguma coisa de inferior e sujeita a esta potência incompreensivel ${ }^{, 388}$.

Por isso, quando Descartes introduziu as instâncias superiores no cenário da Primeira Meditação, nós procuramos nos deter no detalhe da exigência da causalidade para as coisas simples e universais, cuja verdade só se torna suspeita quando vinculada a causas imperfeitas. Do contrário, elas ficam numa situação muito semelhante, quiçá idêntica, à das Ideias platônicas ou das verdades eternas suarezianas. É a criação que lhes confere sua veracidade, pois a causalidade eficiente as submete ao ser infinitamente perfeito e não a quaisquer falsas e imperfeitas causas. Se Deus não for seu criador, parece impossível obter um conhecimento verdadeiro acerca da natureza das coisas, pois nos faltaria algo como uma espécie de certificado de procedência ${ }^{389}$. A razão é

\footnotetext{
${ }^{387}$ A Mersenne, 6 de maio de 1630. AT I, 149.

${ }^{388}$ A Mersenne, 6 de maio de 1630. AT I, 150.

${ }^{389}$ Segundo Gouhier, as hipóteses do Deus enganador e do gênio maligno só se tornam viáveis graças à admissão da criação de verdades eternas: "se nossas verdades eternas são tais porque estão escritas na substância inteligível de Deus, eu não posso [...] formular a hipótese de um Deus me enganando no momento em que as vejo"(H. Gouhier. La pensée Métaphysique de Descartes, p. 259). As verdades no entendimento, por sua vez, trazem à tona o problema da existência de um limite interno em Deus, em razão da precedência do intelecto à sua vontade, ou seja, a vontade divina é limitada pela necessidade das verdades presentes no seu intelecto. Porém, "não há ordem, nem lei, nem razão de bondade e de verdade que não dependa dele", adverte Descartes nas Sextas Respostas. (AT IX, 235).

As hipóteses das instâncias superiores surgiram em razão da situação momentânea das coisas simples e universais. Que situação? A de coisas que seriam por si. Como Descartes é convencido de que lhes é necessária uma causa, e que esta só pode ser eficiente, a busca pela causa conduz à hipótese das instâncias
} 
incapaz de conferir necessidade, eternidade e imutabilidade às coisas. É necessário, portanto, as verdades serem estabelecidas por Deus, cuja existência "é a primeira e a mais eterna de todas as verdades que podem ser, e a única de onde procedem todas as outras", as quais são alguma coisa de inferior e sujeita à potência incompreensível ${ }^{390}$, afirma Descartes.

Agora podemos repetir a pergunta dirigida por Mersenne a Descartes: "in quo genere causae Deus disposuit aeternas veritates?"391 Sendo Deus a fonte de todas as verdades, poder-se-ia aventar a possibilidade delas provirem de Deus por um gênero de causa que não a criação. Tal possibilidade evoca Deus como causa exemplar das verdades. Para Tomás de Aquino, os exemplares são idênticos às ideias. Citando Agostinho, Tomás diz que "as ideias são as formas contidas na inteligência divina" 392 . Dessa maneira, não há possibilidade de pensarmos na existência das verdades fora de Deus: "Portanto, é necessário admitir-se que na divina sabedoria estão as razões de todas as coisas, a que chamamos antes ideias, isto é, formas exemplares existentes na mente divina" ${ }^{393}$. Tomando Deus como causa exemplar, mantemos as ideias na mente divina e evitamos lhes conferir uma existência externa a Deus ou mesmo independente dele. Todavia, Descartes assegura que tais verdades "não são mais necessariamente conjuntas à sua essência, tal como as outras criaturas" ${ }^{\text {,394 }}$. Na visão cartesiana, a admissão da causalidade exemplar, se, por um lado, evita o problema da independência das essências, por outro, prejudica a simplicidade divina. Primeiro, porque esses exemplares limitam o alcance da onipotência, pois Deus só pode criar aquilo que é

superiores. No entanto, o gênio, por exemplo, aparece como uma espécie de demiurgo maligno e não parece ser visto como causa das coisas simples e universais. Sua tarefa seria a de nos fornecer dados que não correspondem às verdades, às quais apenas ele teria acesso. A hipótese do gênio maligno me permite vê-las como verdades incausadas. Num contexto teológico, seria o problema da coexistência de Deus e do diabo. Suponhamos, pois, que as verdades fossem incausadas, e houvesse o diabo. Elas não provêm de Deus - que, com diabo ou sem diabo, permanece veraz - mas meu acesso a elas torna-se inviável, em razão da presença de alguém disposto a oferecer algo cuja aparência sedutora de verdade neutralizaria todos os meus mecanismos de dúvida, levando-me a assentir ao falso como verdadeiro, ou então, no caso de nossos mecanismos resistirem ao aspecto sedutor do objeto oferecido, permaneceríamos do mesmo jeito sem acesso à verdade. Assim, se, por um lado, a tese de criação das verdades viabiliza o recurso às instâncias superiores, por outro, a criação delas por Deus elimina definitivamente as instâncias superiores. De todo modo, o centro da gravidade do problema não reside tanto em que elas sejam criadas, como Gouhier afirma em outra passagem: "se elas não fossem criaturas e sua eternidade fosse aquela do entendimento divino, não seria mesmo possível supor um engano transcendental” (Idem, p. 286), mas que elas não sejam criadas por Deus, isto é, como provindo de uma causa que não o próprio Deus, ou como verdades incausadas.

${ }^{390}$ Cf. A Mersenne, 6 de maio de 1630. AT I, 150.

${ }^{391}$ A Mersenne, 27 de maio de 1630. AT I, 151.

${ }^{392}$ Agostinho apud Tomás de Aquino. Suma Teológica, I, q. 44, a. 3.

393 Tomás de Aquino. Suma Teológica, I, q. 44, a. 3.

${ }^{394}$ A Mersenne, 27 de maio de 1630. AT I, 152. 
prescrito pelo seu intelecto, ao qual é inerente o princípio de não contradição. Deus seria então condicionado pelo seu intelecto. Resulta, daí, uma precedência e supremacia do intelecto à vontade divina, contrariando a absoluta simplicidade divina.

Outra alternativa seria conceber as verdades eternas derivando de Deus por emanação. Grosso modo, emanação é um processo por meio do qual a realidade deriva de um princípio único. Na emanação, "o agente extrai de si um ser semelhante; o que emana é da mesma natureza do princípio de onde o agente procede, é seu efeito

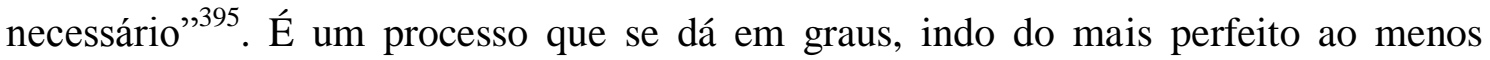
perfeito, chamado degradação. Emanação e criação se opõem, não somente porque a criação demarca uma distinção radical entre o ser de Deus e o de sua obra, enquanto a emanação concebe o divino imanente à natureza, resultando no panteísmo, mas também porque a criação é um ato livre, enquanto a emanação é necessária, fluindo inexoravelmente da plenitude da essência divina.

Mas como alguma coisa pode proceder de Deus por necessidade sem que isso atente contra a ideia do verdadeiro Deus, ou seja, sem que contrarie a ideia cartesiana de unidade, simplicidade e inseparabilidade divina? Ora, se o emanacionismo é necessário, a onipotência torna-se vazia; se a substância divina se degrada pelo universo, Deus deixa de ser uno e, de algum modo, suas perfeições parecem separadas dele e dispersas no universo. A propósito da possibilidade das verdades eternas emanarem de Deus, Descartes garante:

"É certo que ele tanto é autor da essência como da existência das criaturas: ora esta essência outra coisa não é que as verdades eternas: as quais eu não concebo emanar de Deus como os raios do sol, mas eu sei que Deus é o Autor de todas as coisas, e que estas verdades são alguma coisa e, por conseguinte, que ele é seu autor"396.

O que Descartes pretende significar exatamente quando chama Deus de autor? Com efeito, a criação é uma autoria divina, mas nem todo autoria é criação, como a dos pais em relação aos filhos, a do pedreiro em relação ao edifício. Mersenne desejava saber o que Deus teria feito para produzir as verdades eternas. Para Descartes, no mesmo ato pelo qual Deus "as quis e as compreendeu desde toda a eternidade, ele as

\footnotetext{
395 B. Mondin. Quem é Deus, p. 349.

${ }^{396}$ A Mersenne, 27 de maio de 1630. AT I, 152.
} 
criou" ${ }^{\text {397 }}$. Todavia, a compreensão de Mersenne da criação é a mesma daquela elaborada pelos teólogos e filósofos cristãos, ou seja, ele atribui a "palavra criação somente à existência das criaturas" ${ }^{\text {} 398}$. Para Descartes essa distinção perde o sentido, uma vez que "Deus é Autor tanto da essência quanto da existência das criaturas". Assim, o termo autor equivale a criador. Eis a passagem na íntegra:

"Vós perguntais o que Deus fez para produzi-las. Eu digo que no mesmo ato pelo qual ele as quis e as compreendeu desde toda a eternidade, ele as criou, ou ainda (se vós atribuís a palavra criar somente à existência das criaturas) ele as dispôs e fez. Pois em Deus é uma mesma coisa querer, entender e criar, sem que um preceda o outro, nem mesmo logicamente". 399

E quanto à pergunta de Mersenne sobre o gênero de causa pelo qual as verdades eternas foram instituídas, Descartes responde dizendo "que in eodem genere causae [pelo mesmo gênero de causa] que ele criou todas as coisas, ou seja, ut efficiens \& totalis causa [como causa eficiente e total] ${ }^{, 400}$.

Ora, se essa afirmação aparecesse apenas na Correspondência, o argumento da marginalidade, depois de tudo o que vimos apresentando, talvez tivesse alguma força. No entanto, essa passagem se coaduna com a dos Princípios, citada outras vezes, onde se afirma ser "Deus a verdadeira causa de todas as coisas que são ou podem ser", pela qual só há uma possibilidade de compreensão, a saber, como "a causa eficiente de todas as coisas" 401 .

Curiosamente, Descartes não apenas se refere a Deus como causa eficiente, cujo significado já foi explicitado mais acima, mas também total. Que isso quer dizer? Significa que o poder criador abrange o céu, a terra e o que eles contêm, conforme a cosmologia cristã ensina. Porém, não só a estes seres ${ }^{402}$. Deus é criador universal, afirmara Descartes na Terceira Meditação ${ }^{403}$, pelo que se entende que ele "tanto é Autor da essência quanto da existência das criaturas" 404 . É nesse sentido que Deus é causa eficiente e total.

\footnotetext{
${ }^{397}$ Idem.

${ }^{398}$ Ibidem, 152-153.

399 Idem

${ }^{400}$ Ibidem. AT I, 151-152.

${ }^{401}$ Princípios, art. XXIV e XXVIII respectivamente.

${ }^{402}$ Cf. Segundas Respostas. AT IX, 131.

${ }^{403}$ Cf. AT IX, 32

${ }^{404}$ A Mersenne, 27 de maio de 1630. AT I, 152
} 


\subsection{Existência e criação das coisas materiais}

\subsubsection{Existência das coisas materiais}

À época de Descartes, a existência de uma realidade material era admitida como verdade evidente e inquestionável, fundamento real da crença de que nosso conhecimento tem origem nos sentidos, da qual somos persuadidos desde a infância. É a existência da realidade material sensível que explica a existência das ideias sensíveis. Assim, basta uma rápida análise da memória para encontrar o sentimento de que possuo um corpo, que, afetado por outros corpos, tem sensações de dor, prazer, apetites e paixões. Dirigidos ao exterior, os sentidos percebem a multiplicidade de objetos, reconhece-os distintos uns dos outros e distintos de mim mesmo ${ }^{405}$. Graças ao aspecto coercitivo e involuntário dessas representações, somos persuadidos de que verdadeiramente as ideias das coisas sensíveis exteriores são causadas pelas próprias coisas ${ }^{406}$, algo que também pode ser comprovado pela aplicação do princípio de causalidade à realidade objetiva da ideia ${ }^{407}$. Com efeito, se tenho ideias sensíveis é evidente que é causada por alguma coisa sensível à qual a ideia corresponde. Dessa maneira, "eu me persuadia facilmente que não havia nenhuma ideia em meu espírito, que não tivesse passado antes pelos meus sentidos" 408 .

Em contrapartida, além de inúmeras evidências acerca do engano dos sentidos, Descartes alega que a causa originária de nossas representações sensíveis pode ser encontrada no próprio sujeito, seja na faculdade oculta, seja em outras ideias nas quais elas teriam origem. Com isso, o primado da evidência da existência de uma realidade material exterior apreendida direta ou através dos sentidos, comum aos realistas, é descartado como falso fundamento. Felizmente, Descartes encontra na nova via, através da qual se poderá conhecer de forma verdadeira e certa a existência da realidade material exterior.

Conforme mencionamos acima, a existência do Deus veraz elimina a faculdade oculta, afastando a hipótese de que as ideias sensíveis sejam voluntária ou

\footnotetext{
${ }^{405}$ Cf. Sexta Meditação. AT IX, 59.

406 "Pois eu experimentava que elas se apresentavam ao meu pensamento, sem que meu consentimento fosse requerido, de sorte que eu não podia sentir objeto algum, por mais que eu quisesse, se ele não se achasse presente a algum órgão dos meus sentidos, e não estava de modo algum em meu poder não sentilo, quando ele aí se achasse presente" (Sexta Meditação. AT IX, 59).

${ }^{407}$ Cf. R. Landim. Idealismo ou Realismo na Filosofia Primeira de Descartes, p. 149.

${ }^{408}$ Sexta Meditação. AT IX, 60.
} 
involuntariamente causadas pelo sujeito e aumentando consideravelmente a possibilidade da existência da realidade exterior sensível. Porém, o caráter confuso e a falsidade material das ideias sensíveis exigem de Descartes muita cautela em relação a essas ideias. Por isso, ele vê no princípio de clareza e distinção o critério que permite discernir entre as verdadeiras e falsas ideias referentes à realidade sensível. Com efeito, diz ele, "sei que todas as coisas que concebo clara e distintamente podem ser produzidas por Deus tais como as concebo" 409 . Sendo assim, se a investigação criteriosa de Descartes efetivamente demonstrar a existência da realidade exterior, esta desde já é concebida como produto da ação divina.

Sua investigação se inicia com a seguinte consideração:

"É suficiente que eu possa conceber clara e distintamente uma coisa sem uma outra, para estar certo de que elas podem ser postas separadamente ao menos pela onipotência divina; e não importa por que poder essas separação se faça, para me obrigar a julgá-las diferentes" ${ }^{410}$.

A passagem enceta a questão da distinção real entre alma e corpo, entre a res cogitans e a res extensa. Conforme observa Landim, para se estabelecer a distinção real entre duas entidades, é preciso que a ideia de uma seja clara e distintamente completa, independente e diferente da outra. A diferença exige que a ideia não seja obtida através de um processo de abstração ${ }^{411}$. A ideia de que sou uma coisa pensante expressa de forma clara e distinta que sou "uma substância cuja essência ou natureza consiste apenas em pensar" ${ }^{\circ 12}$ e nada além disso lhe pode ser atribuído, ao passo que a ideia que possuo de corpo é a de algo cuja natureza consiste apenas na extensão. Assim, a ideia de coisa pensante exclui a de extensão e a de extensão exclui o pensamento.

Mas a distinção não ocorre apenas no âmbito das ideias. É preciso ainda que ambas as entidades consideradas, no caso mente e corpo, possam existir separadamente uma da outra ${ }^{413}$. Ora, como a natureza da coisa pensante não envolve extensão, nem a da extensão envolve o pensamento, então, conclui Descartes, podem existir independentemente uma da outra e, portanto, são realmente distintas. Além disso, pode-

\footnotetext{
${ }^{409}$ Sexta Meditação. AT IX, 62.

${ }^{410}$ Idem.

${ }^{411}$ Cf. Cf. R. Landim. Op. cit., 153-154.

${ }^{412}$ Sexta Meditação. AT IX, 62

${ }^{413}$ Cf. R Landim. Op. cit., 153.
} 
se ainda verificar se são realmente distintas, analisando seus modos ou acidentes. Com efeito, a distinção real "se aplica às substâncias ou aos modos de substâncias diferentes" ${ }^{\prime 414}$. No sujeito pensante, encontram-se as faculdades de imaginar e sentir, apresentadas como modos ou acidentes distintos da coisa pensante. Embora distintos dela, não podem ser concebidos como existindo separados da substância inteligente de que são modos ou acidentes.

Em contrapartida, outras faculdades como, por exemplo, mover-se no espaço, são modos ou acidentes cuja existência não pode se dar senão numa substância que as comporta. Tal substância só pode ser corpórea ou extensa, pois, explica Descartes, "no conceito claro e distinto dessas faculdades se encontra contido algum tipo de extensão, mas jamais algum modo de inteligência" ${ }^{415}$. Portanto, tanto mente e corpo são substâncias realmente distintas, como os modos inerentes a cada uma são igualmente distintos entre si. Apesar disso, a distinção real entre as substâncias pensante e corpórea ainda não é suficiente para concluir a existência exterior desta última. Descartes recorre à analise da consciência sensível, cujo caráter passivo, receptivo e involuntário conduzirá à demonstração da existência atual da substância corpórea. Diz ele:

"Encontra-se em mim uma certa faculdade passiva de sentir, isto é, de receber e de conhecer as ideias das coisas sensiveis [...] frequentemente representadas sem que eu em nada contribua para tanto, e mesmo amiúde contra a minha vontade ${ }^{, 416}$.

Em primeiro lugar, cabe às ideias sensíveis fornecer a base demonstrativa da existência efetiva da realidade extensa. No entanto, tais ideias são materialmente falsas, isto é, "não conseguem identificar como objetos os conteúdos que elas parecem apresentar à consciência" ${ }^{417}$. Dessa maneira, é impossível tomá-las como representações de objetos. Além disso, anteriormente, elas não resistiram ao argumento da faculdade oculta em mim como sua causa. Se elas não representam objetos, não se pode determinar seu grau de realidade objetiva. Como observa Landim, Descartes sabe que a

\footnotetext{
${ }^{414}$ R. Landim. Op. cit., p. 154.

${ }^{415}$ Sexta Meditação. AT IX, 62.

${ }^{416}$ Ibidem. AT IX, 63.

${ }^{417}$ R. Landim. Op. cit., p. 151.
} 
aplicação do princípio de causalidade às ideias sensíveis é problemática, em razão da indeterminação do grau de realidade objetiva delas ${ }^{418}$.

No entanto, a estratégia cartesiana concentra-se na consciência sensível, cuja passividade necessariamente remete a um princípio ativo. Com efeito, passividade e atividade são termos complementares, isto é, um não pode ser pensado sem o outro. Sendo a consciência sensível passiva, é necessário existir uma faculdade ativa, cuja atividade seja capaz de formar e produzir nessa consciência as ideias sensíveis ${ }^{419}$. Cabe, então, determinar o local onde se encontra a faculdade ativa.

Descartes apresenta duas possibilidades. Ou essa faculdade se acha presente em mim mesmo ou em outrem ${ }^{420}$. Avaliando a possibilidade de essa faculdade estar presente no sujeito, ele a rejeita com base na compreensão que tem de coisa pensante, aquela cuja atividade é pensar. Pensar é também estar presente a todos os seus atos, ou seja, ter consciência de cada um deles. Caso houvesse no sujeito esta faculdade ativa, ela não seria oculta, não produziria um ato sequer sem que eu não tivesse consciência dele. Portanto, declara Descartes:

"É preciso que ela esteja em alguma substância diferente de mim, na qual toda a realidade, que há objetivamente nas ideias por ela produzidas, esteja contida formal ou eminentemente [...] E esta substância é ou um corpo, ou seja, uma natureza corpórea, na qual está contido formal e efetivamente tudo o que existe objetivamente e por representação nas ideias; ou é Deus mesmo, ou qualquer outra criatura mais nobre que o corpo, na qual isto mesmo esteja contido eminentemente $^{, 421}$.

Parece que, com isso, Descartes consegue estabelecer em relação à coisa pensante a distinção, diferença e exterioridade das coisas extensas. Ora, a substância corpórea é realmente distinta da substância pensante e, por conseguinte, pode existir separada e independentemente desta. O caráter passivo da consciência sensível reclama, por conseguinte um princípio ativo, o qual, não podendo existir no sujeito sem o seu conhecimento, existe necessariamente em algo distinto e exterior a ele. Ora, não foi dito

\footnotetext{
${ }^{418}$ Cf. R. Landim. Op. cit., p. 153.

${ }^{419}$ Cf. Sexta Meditação. AT IX, 63.

${ }^{420}$ Idem

${ }^{421}$ Idem.
} 
que Descartes rejeitara a aplicação do princípio de causalidade, em razão do seu caráter problemático, como então ele parece subentendido agora?

De fato, Descartes lança mão do princípio de causalidade. No entanto, explica Landim, o filósofo recorre a ele não para demonstrar a existência das coisas exteriores, e sim com o objetivo de determinar quais das entidades exteriores mencionadas explicaria a passividade da consciência sensível, sendo causa eminente ou formal dessa passividade $^{422}$. Enfim, o princípio de causalidade pretende estabelecer "a proporção de perfeição entre a consciência sensível passiva e a natureza das entidades que poderiam ser causa da passividade" 423 , conclui. Quanto à possibilidade de ser Deus a causa ativa das minhas ideias sensíveis, Descartes a rejeita, como base na veracidade divina:

"Ora, não sendo Deus de forma alguma enganador, é muito manifesto que ele não me envia essas ideias imediatamente por si mesmo, tampouco por intermédio de qualquer criatura, na qual sua realidade não esteja contida formalmente, mas só eminentemente ${ }^{, 424}$.

Portanto, o princípio ativo que age sobre minha consciência sensível se identifica com as coisas exteriores, as quais são causas das ideias sensíveis em mim. Visto não ser eu tal princípio nem alguma faculdade oculta em mim, e não podendo essas ideias provir imediatamente de Deus ou da criatura mais nobre que o corpo; e visto se achar em mim uma forte inclinação natural para crer que as ideias sensíveis são formadas a partir das próprias coisas sensíveis em vez de qualquer faculdade que corrija minha inclinação natural ${ }^{425}$, a correspondência entre minhas ideias e a realidade material está assegurada. Caso contrário, Deus seria enganador; caso "essas ideias partissem ou fossem produzidas por outras causas que não as coisas corpóreas. E, portanto, é necessário confessar que há coisas corpóreas que existem"426.

\subsubsection{Criação das coisas materiais}

\footnotetext{
${ }^{422}$ Cf. R. Landim. Op. cit., p. 155.

${ }^{423}$ Idem.

${ }^{424}$ Sexta Meditação. AT IX, 63.

${ }^{425} \mathrm{Cf}$. Idem.

${ }^{426}$ Idem.
} 
Demonstrada a existência da realidade material, é preciso investigar se ela é ou não por si. Sendo por si, será causa eficiente de si ou incausada. Não sendo, porém, por si, não poderá ser por outra coisa senão Deus.

A tese cartesiana a favor da criação da realidade material já estava presente na apresentação da ideia de Deus como criador de todas as coisas que estão fora dele ${ }^{427}$. Ora, Descartes já apresentou suas provas a favor da exterioridade da coisa extensa ao sujeito. Por outro lado, sendo Deus imaterial, nele não se encontra nenhum vestígio de matéria. Donde se segue que a realidade material pertencerá ao conjunto de coisas existentes fora de Deus. Da concepção de Deus como criador de tudo o que lhe é exterior segue-se que a matéria é uma de suas criaturas.

No Le Monde, a criação da matéria aparece como um pressuposto indispensável à existência de qualquer realidade material possível. Com efeito, mesmo no mundo construído pela imaginação cartesiana, a matéria haveria de ter sido criada por Deus. Sem esse pressuposto, parece impossível investigar as leis físicas que governam o universo $^{428}$. Essa tese também é apresentada na Exposição Geométrica, quando Descartes afirma que "Deus criou o céu e a terra, e tudo o que aí está contido" ${ }^{429}$. E na segunda parte dos Princípios, destinada à exposição da física mecanicista cartesiana, a criação da matéria é igualmente defendida:

"Deus, que pela sua onipotência criou a matéria com o movimento e o repouso, e que conserva agora no universo, por seu concurso ordinário, tanto movimento e repouso quanto colocou nele ao criá-lo",430.

Deus é apresentado como a causa primária, universal e produtora de todos os movimentos existentes no mundo. Foi ele quem estabeleceu todas as leis da natureza ${ }^{431}$, assegurando assim a regularidade do comportamento dos corpos. Sabendo que Descartes admite a criação da matéria, para provar sua criação é preciso retomar os argumentos apresentados pela Terceira Meditação.

Para Descartes, a questão se apresenta da seguinte maneira: ou a realidade material é por si ou será causada. Sendo por si, ela ou será causa eficiente de si ou será

\footnotetext{
${ }^{427}$ Terceira Meditação. AT IX, 32.

${ }^{428}$ Cf. AT XI, 31.

${ }^{429}$ AT IX, 131.

${ }^{430}$ Princípios, Segunda Parte, art. XXXVI.

${ }^{431}$ Cf. Ibidem, art. XXXVII.
} 
incausada. A hipótese de ser causa eficiente de si, considerando o argumento empregado pelo filósofo, é rejeitada, uma vez que a matéria "não pode conter em si mesma as fontes de sua atividade, mobilidade e diversidade" ${ }^{432}$. Restaria apenas considerá-la incausada. Tratar-se-ia de um outro ser eterno e independente de Deus. A independência em relação a Deus de duas maneiras nega sua existência. Em primeiro lugar, se algo é independente de Deus, então este algo é o próprio Deus ${ }^{433}$. Depois, a independência de qualquer coisa que seja em relação ao ser sumamente perfeito é uma prova contra a perfeição divina mesma. De fato, se algo é independente, Deus não é sumamente perfeito, pois haveria algo que a onipotência foi incapaz de produzir. Como a onipotência é uma perfeição, seríamos forçados a concluir que Deus seria imperfeito e, consequentemente, não seria Deus.

Ora, descoberta e demonstrada a existência do ser perfeitíssimo, ao qual pertence a perfeição da onipotência, segue-se a realidade material é causada por Deus, enquanto causa eficiente criadora. Tal concepção está presente nas diversas obras cartesianas.

Para finalizar, queremos destacar a importância da criação universal como garantia da verdade da validade da razão. De acordo com Descartes, se nossas ideias fossem produzidas por outras coisas que aquelas às quais correspondem, Deus seria enganador, ou seja, não há como isentar Deus da responsabilidade na conexão causal entre a ideia em mim e sua correspondente fora de mim. Por que, se posso evitar o erro suspendendo o juízo e, neste caso, a responsabilidade seria totalmente minha?

A resposta se encontra na tese da criação universal. Ora, a verdade procede de Deus. Em última análise, é Deus mesmo quem nos faz conhecer com verdade as coisas não diretamente, é claro, mas por intermédio delas mesmas, cuja existência provém da ação criadora do Deus veraz:

“E primeiramente não há dúvida que tudo o que a natureza me ensina contém alguma verdade. Pois, por natureza, considerada em geral, não entendo agora outra coisa que Deus mesmo, ou a ordem e a disposição que Deus estabeleceu nas coisas criadas. E por minha natureza em particular, eu não entendo outra coisa que o encadeamento ou conjunto de todas as coisas que Deus me deu”,434.

\footnotetext{
${ }^{432}$ Eduardo S. O. Barra. A Metafísica Cartesiana das Causas do Movimento: Mecanicismo e Ação Divina, p. 299.

${ }^{433}$ Terceira Meditação. AT IX, 38.

${ }^{434}$ Sexta Meditação. AT IX, 64.
} 
Obviamente, os ensinamentos da natureza contêm verdades. Com efeito, significando num primeiro sentido Deus mesmo, sei que "ele é sumamente veraz e doador de toda luz, a ponto de ser absolutamente contraditório que ele nos engane, ou que seja própria e positivamente a causa dos erros aos quais estamos expostos" ${ }^{\text {435. }}$. Sendo a ordem ou a disposição das coisas, uma vez que todas as coisas são criaturas do Deus veraz, a ordem nelas existente foi estabelecida por ele. Quanto à minha natureza criada, Descartes afirma no Discurso que Deus imprimiu em nós as noções das leis que ele estabeleceu na natureza ${ }^{436}$.

Dessa maneira, pode-se entender por que Deus seria enganador se, enquanto criador universal e causa eficiente e total de tudo o que é, tivesse me criado com as noções correspondentes às coisas criadas por ele e, ao contrário, tivessem outras causas que as coisas mesmas. Por intermédio de suas criaturas, Deus garante à razão, de modo indubitável e seguro, o acesso às coisas das quais é ele mesmo o autor.

435 Princípios, art. XXIX.

${ }^{436}$ Discurso do Método, p. 69. 


\section{CONCLUSÃO}

\section{Consequências da universalidade da noção cartesiana de criação}

A essa altura da presente pesquisa, acreditamos ter conseguido mostrar a existência de uma teoria cartesiana da criação, cuja noção de criação assume um alcance universal ao estender-se às realidades eternas e imutáveis. A teoria cartesiana da criação não apenas surge em decorrência da queda da cosmologia cristã realista ante os ataques da dúvida, como também aparece como fundamento da teoria da livre criação das verdades eternas, acusada por alguns intérpretes do cartesianismo de incompatibilidade com o sistema cartesiano.

Assim como para a tradição cristã, para Descartes criar é essencialmente um ato exclusivo de Deus, pelo qual uma coisa é trazida ex nihilo à existência. Todavia, enquanto a tradição cristã restringe a criação à produção das substâncias simples (afora Deus) e compostas, ou seja, o ato criador produz os seres existentes, Descartes, ao contrário, confere à noção um caráter essencialmente universal, que não se limita à existência, mas abrange as verdades eternas - no sentido amplo que esta noção possui e a existência dos seres. Justamente por estender o conceito de criação às realidades eternas, imutáveis e necessárias a tese cartesiana causa perplexidade dentro e fora do cartesianismo.

A universalidade da criação estabelece a absoluta dependência de todas as coisas em relação a Deus pelo mesmo gênero de causalidade pelo qual a tradição cristã lhe vinculava apenas os existentes, qual seja mediante a causalidade eficiente. Este é o aspecto essencial e radical do conceito cartesiano de criação que o separa definitivamente da concepção cristã. Sustentada e desenvolvida nas obras do cânone cartesiano, a noção de criação se impõe como fundamento sobre o qual se assenta a teoria da livre criação das verdades eternas, cuja acusação de marginalidade parece agora descartada.

Aliás, apesar das divergências interpretativas sobre a teoria das cartas, seja quanto à sua marginalidade, seja quanto à sua compatibilidade ou incompatibilidade com o sistema cartesiano, há certa unanimidade entre os estudiosos em considerá-la extravagante. A extravagância aparece agora não tanto como uma consequência isolada, limitada à teoria da livre criação das verdades eternas, mas como uma consequência da noção cartesiana de criação, segundo a qual criar é instituir as coisas materiais e 
espirituais finitas, as eternas e necessárias e os possíveis. Se então, temendo os riscos decorrentes da teoria das cartas, houve quem pressupusesse seu posterior abandono em razão das consequências desastrosas que ela acarretaria ao sistema cartesiano, agora talvez fosse necessário postular o abandono do sistema cartesiano em razão da teoria da criação sustentada nas Meditações. Torna-se, pois, inviável separar a teoria da livre criação do sistema cartesiano, já que neste se encontra a teoria da criação que lhe dá fundamento.

Outra unanimidade entre os intérpretes do cartesianismo se refere à aceitação de uma única maneira válida de Descartes compreender o conceito de criação. Em toda a tradição cristã, a criação compreendia a instauração divina de um aspecto específico da totalidade do real, as substâncias simples e compostas, por cuja ação Deus concedia existência finita a todas elas. Parece ser esta a compreensão admitida pelos estudiosos. Porque a consideram válida para Descartes, inúmeros problemas são extraídos da noção cartesiana da criação ${ }^{437}$.

Se Descartes tivesse vinculado a criação apenas às substâncias existentes em conformidade à tradição cristã, certamente não se encontrariam maiores problemas em sua teoria. Para esta, a criação institui a realidade contingente, ou seja, algo que recebeu de Deus a existência, mas que poderá ou deixará de existir. Se o conceito cartesiano de criação é idêntico ao da tradição cristã, então a universalidade conferida a ele por Descartes acarreta, de fato, uma contradição evidente. Com isso já se deixa claro que as consequências concernentes à universalidade do conceito cartesiano de criação se referem especificamente à criação das verdades eternas: os princípios do entendimento, as coisas simples e universais, todas as classes de verdades necessárias, as essências ou naturezas possíveis e as eternas e imutáveis. Ao afirmar sua criação, estar-se-ia ia sustentando ao mesmo tempo e sob o mesmo aspecto que essas essências ou naturezas são criadas e eternas. Seria uma afirmação contraditória à luz do significado tradicional de criação, para o qual criação é incompatível com necessidade, eternidade ou imutabilidade. O criado é necessariamente contingente. Além de contraditória, a posição cartesiana acarretaria um universo onde nada mais há de necessário, e deflagraria a impossibilidade da ciência como conhecimento do necessário.

\footnotetext{
${ }^{437}$ Tratamos desses problemas na dissertação de mestrado Descartes: A Livre Criação das Verdades Eternas, do capítulo terceiro ao quinto. Aqui serão brevemente retomados aqueles resultantes do conceito de criação, o qual, porque costuma ser entendido apenas no sentido dado pela tradição cristã, acarreta dificuldades à teoria da livre criação das verdades eternas.
} 
Ao contrário da tradição cristã, e do entendimento comum entre os intérpretes do cartesianismo, o conceito cartesiano de criação não se restringe a um determinado aspecto da realidade, pois para Descartes a criação não é uma ação restrita e limitadora do poder divino. Por isso, ele lhe confere alcance universal. Assim, Deus cria tanto os seres contingentes quanto aqueles eternos, imutáveis e necessários. E a criação destes em nada lhes prejudica a eternidade, a imutabilidade e a necessidade. Ao contrário, fundam-se na eterna e necessária imutabilidade do ser divino, como se pode verificar em várias afirmações de Descartes, entre as quais citamos as seguintes:

"Dirão que se Deus estabeleceu estas verdades, ele as poderia mudar como um rei às suas leis; o que é preciso responde que sim, se sua vontade pode mudar. - mas eu as compreendo como eternas e imutáveis - e eu julgo o mesmo de Deus ${ }^{438}$.

A passagem explicita e combate o caráter mutável do antigo entendimento de criação. Se algo é criado por Deus, então é mutável. Afirmando a criação das verdades eternas, Descartes estaria admitindo-as como mutáveis. Ora, ele afirma sua criação, explicitando também que, para ele, criação não é sinônimo de contingência. As verdades eternas, conquanto criadas, são imutáveis e eternas, pois seu caráter eterno e imutável está fundado na própria imutabilidade divina. Como que explicando a citação anterior, outra passagem afirma:

"Que Deus tenha querido que algumas verdades fossem necessárias, não quer dizer que ele as tenha querido necessariamente; pois uma coisa é querer que elas fossem necessárias, e outra é querer necessariamente ou ser necessitado a quer, $^{, 439}$.

Sendo assim, a criação tem, de fato, alcance universal, pois o ato criador se estende para além de uma classe de seres, instituindo, pelo mesmo gênero de causa, as coisas eternas e imutáveis com a necessidade que lhes é própria. Consequentemente, a equivalência exclusiva entre criação e contingência torna-se problemática. Com efeito, essas verdades eternas são criadas por Deus com a mais inteira necessidade, garante

\footnotetext{
${ }^{438}$ A Mersenne, 27 de maio de 1630. AT I, 145-146.

${ }^{439}$ A Mesland, 2 de maio de 1644. AT IV, 118-119.
} 
Descartes a Burman ${ }^{440}$. A universalidade da criação é o meio cartesiano de submeter efetivamente todas as coisas a Deus, excluindo a hipótese mais remota possível de pôr em dúvida a perfeição divina.

De fato, a universalidade da criação é coerente com a ideia cartesiana acerca do Deus criador de todas as coisas que existem fora dele e com o conjunto das provas da criação apresentado na Terceira Meditação. Há uma forte razão em Descartes para defender a necessidade de todas as coisas serem criadas por Deus. Uma dessas razões consta da segunda prova pelos efeitos, que analisa a possibilidade de alguma coisa ser por si, ou seja, ser causa de si ou desprovida de qualquer causa. Ora, diante da demonstração da existência de Deus, o qual é a causa da ideia que tenho dele como o ser perfeitíssimo, nenhuma entidade submetida à mesma análise argumentativa da Terceira Meditação sairia daí como uma coisa que é por si, quer consideremos os seres materiais, a coisa pensante ou as naturezas eternas e imutáveis sem, ao mesmo tempo, destituir Deus da perfeição. Por isso, a Terceira Meditação afirma a causalidade universal, ou seja, demonstrada a existência divina, nenhum ser é por si e, consequentemente, é necessariamente causado por Deus ${ }^{441}$. Isso significa que tudo depende absolutamente dele, tal como se depreende das Quartas Respostas:

"Quando se pergunta se alguma coisa pode se dar o ser a si mesma, quer-se saber apenas se a natureza ou essência de alguma coisa pode ser tal que não tenha necessidade de causa eficiente para ser ou existir" ${ }^{\prime 42}$.

Conhecida a existência de Deus, torna-se impossível supor algum ser cuja natureza prescinda da causalidade criadora. Tal suposição atinge diretamente a perfeição divina. Com efeito, aceitar algo independente de Deus consiste em admitir pelo menos um ser cuja natureza ou essência a onipotência não foi capaz de criar. Evidentemente a perfeição divina fica comprometida, e Deus rebaixado a uma instância inferior e, portanto, imperfeita:

"É, com efeito, declara Descartes, falar de Deus como de um Júpiter ou Saturno, e sujeitá-lo ao Estige e aos Destinos, dizer que essas verdades são independentes dele ${ }^{, 443}$.

\footnotetext{
${ }^{440}$ Cf. L'Entretien avec Burman. AT V, 166-167.

441 Terceira Meditação. AT IX, 38-40.

${ }^{442}$ AT IX, 186.
} 
De fato, se algo é, mas seu ser não proveio de Deus, imediatamente o poder divino torna-se duvidoso. Deus, portanto, não é onipotente; algo lhe escapa. Também deixa de ser perfeito, haja vista ser a onipotência uma verdadeira perfeição. Torna-se então válida para Deus a aplicação da argumentação desenvolvida na Terceira Meditação que resultou na refutação da coisa pensante como ser por si. De fato, como pode Deus criar todas as coisas do nada, algo que demanda um poder imenso e, no entanto, não ter poder para criar e conservar as naturezas eternas e imutáveis? Quem pode o mais, pode o menos; e se Deus não pôde o menos, não é, portanto, Deus. Assim, se as verdades eternas não têm uma causa divina, Deus é esvaziado da perfeição.

A universalidade da noção cartesiana não ocasiona unicamente o problema da contingência do necessário. Em virtude da caracterização da vontade divina como indiferente, o alcance da criação se estenderia aos impossíveis, ocasionando, assim, a possibilidade lógica do que é logicamente impossível, que corresponderia a uma nova ordem do criado e expressaria de maneira ainda mais radical a universalidade da criação.

Isso, no entanto, poderia acarretar sérias dificuldades ao sistema cartesiano. Primeiro, se os impossíveis ou contraditórios são logicamente possíveis, porque a razão ainda os concebe como impossíveis? Depois, sendo criados por Deus, por que ele nos privou da faculdade de conhecê-los? Em segundo lugar, a criação indiferente do que é logicamente impossível representa a negação do princípio de não contradição e, consequentemente, nega a necessidade das verdades, pois ao violar esse princípio fazendo com que fossem verdadeiras as proposições contraditórias, Deus torna tudo possível $^{444}$. Ora, onde tudo é possível, nada é necessário. Consequentemente há uma negação das verdades necessárias. A primeira dificuldade é fruto de uma análise meramente epistêmica da necessidade. A segunda consiste numa interpretação possibilista, derivada da absoluta indiferença da onipotente vontade divina. Essas interpretações se apoiam em algumas cartas onde Descartes tematiza a indiferença divina. De uma delas extraímos a seguinte passagem:

"Para a dificuldade de conceber como foi livre e indiferente a Deus fazer com que não fosse verdade que os três ângulos do triângulo fossem iguais a dois retos, ou geralmente que os contraditórios não podem ser conjuntamente,

\footnotetext{
443 A Mersenne, 15 de abril de 1630. AT I, 145.

${ }^{444}$ Cf. M. Gleizer. Considerações acerca da Doutrina da Livre Criação das Verdades Eternas, p. 191.
} 
podemos facilmente suprimi-la considerando que a potência divina não pode ter nenhum limite ${ }^{, 445}$.

Essa passagem parece declarar que do ilimitado poder de Deus, cuja vontade é indiferente, resulta que os contraditórios existem efetivamente. Tal entendimento ganha ainda mais força se associado à tese cartesiana da simplicidade divina. Segundo ela, existe em Deus uma absoluta unidade entre entender, querer e criar, de modo que no mesmo ato em que ele entende uma coisa, ele a quer e cria ${ }^{446}$. Assim, diante da afirmação de que Deus tem o poder de fazer o que para nós é contraditório, resulta que tal coisa já estaria feita, pois, se seu intelecto entende isso, dada a unidade absoluta entre este e sua vontade, Deus não pode deixar de criar. Com efeito, a indiferença da vontade divina é incompatível com o livre arbítrio, no qual algo se apresentaria ao intelecto divino e a vontade escolheria criar ou não. Se os contraditórios são uma realidade possível, ou seja, não contraditória, por que nossa razão não consegue conceber sua possibilidade, já que o princípio de não contradição é um princípio do entendimento e de inteligibilidade do real?

Segundo Frankfurt, Descartes almeja, na verdade, estabelecer uma cisão entre a racionalidade humana e a estrutura última da realidade, pois, como o próprio filósofo declara, o princípio de não contradição assim como a necessidade é algo interno ao intelecto finito e válido apenas para ele. Por outro lado, "Deus é uma causa cuja potência ultrapassa os limites do entendimento humano, e a necessidade das verdades não excede o nosso conhecimento" ${ }^{\text {447 }}$. Pelo contrário, elas são inferiores a Deus e sujeitas à sua potência incompreensível ${ }^{448}$. Dessa maneira, se no instante em que entende algo, ele o quer e cria, então se ele concebe a possibilidade daquilo que é logicamente impossível, segue-se que de algum modo isso existe, embora nosso intelecto seja incapaz de conhecê-lo:

"nosso espírito é finito, e criado de tal natureza, que ele pode conceber como possíveis as coisas que Deus quis verdadeiramente possíveis, mas não de tal,

\footnotetext{
${ }^{445}$ A Mesland, 2 de maio de 1644. AT IV, 118-119.

${ }^{446}$ Cf. A Mersenne, 27 de maio de 1630. AT I, 152.

${ }^{447}$ A Mersenne, 6 de maio de 1630 . AT I, 150.

${ }^{448}$ Cf. Idem.
} 
que também pudesse conceber como possíveis as que pudesse tornar possíveis, mas que ele entretanto quis tornar impossíveis" 449.

Ora, o final da passagem se contrapõe às duas interpretações em análise, pois descarta a possibilidade efetiva dos impossíveis. Por outro lado, Descartes preserva a onipotência divina dizendo que se algo é impossível, sua impossibilidade foi estabelecida por Deus. A onipotência divina permanece ilimitada. E as coisas uma vez estabelecidas por ela são imutáveis:

"Assim como os poetas fingem que os Destinos foram na verdade feitos por Júpiter, e que depois de terem sido uma vez estabelecidos, ele se obrigou a conservá-los, assim também eu não penso, na verdade, que as essências das coisas, e estas verdades matemáticas que delas podemos conhecer, sejam independentes de Deus, mas penso que porque Deus assim quis e que ele assim dispôs, elas são imutáveis e eternas" ${ }^{450}$.

Outra passagem importante se encontra nas Sextas Respostas, onde se afirma:

"Uma vez que ele quis que os três ângulos de um triângulo fossem necessariamente iguais a dois retos, é agora verdade que isto é assim, e não pode ser de outra maneira" ${ }^{451}$.

Conforme evidenciamos no estudo sobre a teoria da livre criação das verdades eternas, o possibilismo descontextualiza as afirmações de Descartes. Primeiramente, a indiferença visa garantir a Deus a precedência absoluta a todas as coisas, de modo que nada, nem mesmo o princípio de não contradição, interponha-se entre Deus e sua obra. Em Tomás de Aquino, por exemplo, o princípio de não contradição era o princípio inerente ao ser e, portanto, inerente a Deus. Para Descartes, Deus não pode ser limitado quer interna quer externamente, conforme garante a seguinte passagem:

\footnotetext{
${ }^{449}$ A Mesland, 2 de maio de 1644. AT IV, 118.

${ }^{450}$ Quintas Respostas. AT VII, 380.

${ }^{451}$ AT IX, 233.
} 
"Não há ordem, nem lei, nem razão de bondade e de verdade que não dependa dele; de outra maneira, [...] ele não teria sido totalmente indiferente a criar as coisas que ele criou" ${ }^{452}$.

Como nada precede a vontade divina, o contraditório ou impossível não é uma possibilidade que Deus poderia escolher atualizar, negar ou violar ${ }^{453}$. A possibilidade de escolha configura a vontade divina como livre arbítrio, além de contrariar a simplicidade divina. Quanto à possibilidade de Deus negar o princípio, é preciso notar que para Descartes a vontade divina é imutável. Suponhamos, finalmente, em razão do poder ilimitado, que Deus possa violar o princípio, criando um estado de coisas logicamente impossíveis, como se elimina essa dificuldade? Estudando a teoria da livre criação das verdades eternas, propusemos como solução a admissão cartesiana da tese da distinção entre a potência absoluta e a potência ordenada de Deus, explicitamente evocada na passagem mais acima, extraída das Quintas Respostas ${ }^{454}$.

A tese da indiferença, de acordo com Descartes, pretende nos fazer "conhecer que Deus não pode ter sido determinado a fazer com que fosse verdade que os contraditórios não podem ser conjuntamente, e que, por conseguinte, ele poderia fazer o contrário" $^{455}$. Isto, por sua vez, conduz à seguinte conclusão:

“Que Deus tenha querido que algumas verdades fossem necessárias, não quer dizer que ele as tenha querido necessariamente; pois uma coisa é querer que elas fossem necessárias, e outra é querer necessariamente ou ser necessitado a querer, ${ }^{356}$.

Portanto, a universalidade da criação recusa tanto a consequência da contingência da necessidade quanto a da possibilidade lógica do que é logicamente impossível. Ambas as interpretações têm em comum a compreensão de que o conceito de criação implica necessariamente na negação do necessário, eterno e imutável.

\footnotetext{
452 Sextas Respostas. AT IX, 235.

${ }^{453}$ Essa é uma das ideias analisadas por Richard La Croix, em seu artigo Descartes on God's Ability to Do the Logically Impossible.

${ }^{454}$ Cf. AT VII, 380.

${ }^{455}$ A Mesland, 2 de maio de 1644. AT IV, 118.

${ }^{456}$ Ibidem. 118-119.
} 
A nosso ver, provavelmente a ideia de perfeição divina conjugada com a tese da incompreensibilidade possa nos mostrar uma solução mais satisfatória para os problemas aqui levantados.

\section{A perfeição divina e a instituição do que é logicamente impossível}

Na exposição da primeira prova da existência de Deus pelos efeitos, Descartes apresenta de duas maneiras a ideia que possui do ser sumamente perfeito. Nela, aparece aquilo que Curley apresenta como uma espécie de listagem dos atributos divinos. Comparando a versão francesa à latina, observa-se certas diferenças na listagem da versão latina, na da versão francesa, e entre as versões latina e francesa, de forma que numa lista aparece determinado atributo que, por sua vez, é omitido na outra. Esta não é uma característica peculiar da Terceira Meditação.

Segundo Curley, considerando como listas separadas as passagens que variam na versão francesa, somam-se cinco listas no total ${ }^{457}$. Aproveitando o levantamento feito por ele, a Primeira Meditação refere-se a Deus como "meu criador, onipotente, sumamente bom e fonte de verdade" ${ }^{\text {458 }}$. Na Terceira Meditação, são apresentadas mais duas listas, onde a versão francesa contém atributos que não aparecem na versão latina. A primeira lista traz os seguintes atributos: "soberano, eterno, infinito, imutável, onisciente, onipotente, e criador de todas as coisas que existem". A segunda lista surge quando Descartes explica o que entende pelo nome Deus: infinito, eterno, imutável, independente, sumamente inteligente, sumamente poderoso e criador da coisa pensante e de tudo que existe ${ }^{459}$. Com isso, já teríamos as cinco listas mencionadas por Curley. Por outro lado, o artigo XIV dos Princípios expressa a ideia de Deus como "sumamente poderoso, sumamente inteligente e sumamente perfeito" 460 .

Essas listas e outras que poderiam ainda ser mencionadas não apenas se distinguem umas das outras como também alguns atributos mencionados numa não ficam até as últimas, como ocorre com o atributo da bondade. De acordo com Curley, esse não é um aspecto acidental em Descartes, mas prepara o caminho para a definição

\footnotetext{
${ }^{457}$ Cf. E. Curley. De volta ao Argumento Ontológico, p. 67.

458 AT VII, 21-22. AT IX, 16-17.

${ }^{459}$ Primeira lista extraída de AT VII, 40 e AT IX, 32. Segunda lista corresponde a AT VII, 45 e AT IX, 35-36. Em itálico, o atributo que Curley não menciona. Em negrito, aqueles que constam apenas da versão francesa. Portanto, uma lista na Primeira Meditação e, se consideradas independentes, duas na versão latina e duas na versão francesa, totalizando cinco listas.

${ }^{460}$ Art. XIV.
} 
de Deus como ente sumamente perfeito, reduzindo assim todos os atributos a um predicado único ${ }^{461}$. Nesse ponto Curley discorda inteiramente da interpretação de Beyssade, apresentada na seguinte passagem:

"Não é possível uma redução a um predicado único. Nem onipotência nem perfeição podem exercer esse papel. Deus não possui atributo principal, exatamente porque a unidade absoluta desses atributos, por sua relação com todo outro atributo, implica que cada atributo é, à sua maneira, identicamente infinito ${ }^{, 462}$.

Como Curley, inclinamo-nos a admitir o papel especial que o atributo da perfeição adquire frente aos outros, conforme Descartes sustenta na Exposição Geométrica, dizendo que "a substância que nós entendemos ser sumamente perfeita, e na qual não concebemos nada que encerre algum defeito, ou limitação de perfeição, chama-se Deus" ${ }^{\$ 63}$. Parece claro que na ideia de Deus como sumamente perfeito está implícito que ele contém todos os atributos, os quais são entendidos como perfeições. Ademais, Curley salienta ainda que é o atributo da perfeição que dá o fundamento no qual todos os atributos são necessariamente conectados uns aos outros, assim como também fornece o critério ao intelecto finito para bem julgar se um determinado atributo pertence ou não a Deus ${ }^{464}$. Seja, pois, a perfeição o atributo principal.

Precisamos então saber de que maneira a perfeição divina contribui para eliminar as dificuldades derivadas da universalidade da criação estendida aos impossíveis, acarretando os problemas levantados por La Croix. Tais problemas podem ser fruto de uma concepção que identifica a indiferença da vontade divina à indiferença da vontade humana e a caracteriza como contingente ${ }^{465}$.

\footnotetext{
${ }^{461}$ Cf. Curley. Op. cit., p. 67-69.

462 J.-M. Beyssade. The Idea of God and Proofs of his Existence, p. 187. A passagem também aparece citada pelo próprio Curley (op. cit., p. 69).

${ }^{463}$ AT IX, 125.

${ }^{464}$ E. Curley. Op. cit., p. 70.

465 A contingência da vontade divina é admitida por Curley. De fato, toda vontade fundada sobre os atos de um agente, caracteriza-se como contingente. Assim, quando quero algo, é logicamente possível que não o queira. A intenção de Curley, porém, era de assegurar a necessidade das verdades eternas e refutar o possibilismo. Em se tratando da onipotência divina, algo é necessário se Deus assim o quiser. (Cf. E. Curley. Descartes on the Creation of the Eternal Truths, p. 576-583). Van Cleve, no entanto, seguindo as mesmas premissas de Curley, ou seja, partindo da caracterização da indiferença divina como contingência, derivou o possibilismo universal que tornaria inconsistente a posição cartesiana. Para ele, o problema da tese cartesiana reside em fundar as verdades eternas em algo contingente, como é o caso da vontade divina (Cf. J. Van Cleve. Descartes and the Destruction of the Eternal Truths, p. 58-62).
} 
Parece que a razão para identificar a indiferença da vontade divina à da vontade humana encontra-se na Quarta Meditação, onde Descartes caracteriza a liberdade humana como indiferente e afirma ser a indiferença uma imperfeição:

"Esta indiferença que sinto, quando não sou impelido para um lado mais do que para outro pelo peso de alguma razão, é o mais baixo grau de liberdade, e antes faz parecer um defeito no entendimento do que uma perfeição na vontade ${ }^{, 466}$.

As Meditações não falam da liberdade divina como indiferença. Assim, se a Quarta Meditação apresenta a indiferença da vontade humana como imperfeição, parece então seguir-se disso que indiferença e imperfeição se identificam. De acordo com Descartes, a indiferença pode ser compreendida de dois modos. Negativamente, ela é uma imperfeição, um defeito no entendimento, enquanto positivamente significa poder de escolha, livre-arbítrio. Essa escolha não se exerce sempre entre contrários como bem e mal, podendo versar sobre várias coisas que, embora distintas, são verdadeiramente boas, por exemplo, o estudante que, amante das vastas e boas áreas do saber, escolhe uma determinada área a que se dedicar inteiramente. Considerando inúmeras possibilidades de boas alternativas, a oscilação da vontade e a forte carga de dúvida sobre para que lado pender ficam ainda maior. Essa indiferença não é somente uma imperfeição, mas é inclusive própria de uma criatura incompleta, imperfeita, desprovida de conhecimento intuitivo.

Em contrapartida, a indiferença divina, que só aparece na Correspondência, não pode ter a mesma conotação que a indiferença da liberdade humana. Primeiro, porque impugna toda e qualquer possibilidade de análise de alternativas prévias apresentadas a Deus e, por conseguinte, sua concepção impede-nos de assimilá-la ao livre-arbítrio. A segunda razão leva em consideração a perfeição divina. Deus é o ser sumamente perfeito, pois todas as perfeições. Ora, a vontade divina é uma vontade sumamente perfeita, enquanto a vontade humana é naturalmente imperfeita. É apropriada ao ser imperfeito uma liberdade que se exerce por meio de avaliações de várias possibilidades, dentre as quais elege a que lhe parecer melhor, pois seu conhecimento é discursivo, progressivo e não intuitivo. Essas possibilidades nem sempre são alternativas radicais como, por exemplo, entre bem e mal. Por isso, o ser finito considerará a alternativa que

\footnotetext{
${ }^{466}$ Quarta Meditação. AT IX, 46.
} 
julgar melhor. Do ponto de vista da vontade divina, não nos parece coerente com uma vontade sumamente perfeita o exercício da liberdade por meio de escolhas. Com efeito, como imaginar que um ser cuja vontade é sumamente perfeita oscile entre alternativas, como se lhe faltasse clareza suficiente para decidir ou pairasse alguma dúvida sobre sua decisão? Ora, se a vontade divina é perfeita, não parece ter qualquer necessidade de avaliar alternativas, escolhendo dentre elas a que julgar melhor. Não. Uma vontade perfeita não precisa avaliar, pois nada a precede. Assim, o perfeito sempre acerta de primeira, e "necessariamente" o que faz é o melhor. É o que evidencia a seguinte passagem:

"Por exemplo, não é por ter visto que era melhor que o mundo fosse criado no tempo que desde a eternidade, que ele quis criá-lo no tempo; e ele não quis que os três ângulos de um triângulo fossem iguais a dois retos, porque ele conheceu que isto não se podia fazer de outra maneira etc. Pelo contrário, porque quis criar o mundo no tempo, por isso é assim melhor do que se ele o tivesse criado desde toda a eternidade; e ademais porque ele quis que os três ângulos de um triângulo fossem necessariamente iguais a dois retos, é agora verdade que é assim, e não pode ser de outra maneira" ${ }^{\mathrm{467}}$.

A passagem ainda esclarece o sentido cartesiano da indiferença da vontade divina àqueles que insistem em colocar Deus submetido a qualquer ordem precedente à sua ação, ou ainda avaliando as inúmeras possibilidades postas à sua liberdade. Uma vontade perfeita não avalia o que seria melhor ou pior, o que ela estabelece é indubitavelmente o melhor. Essas categorias fazem sentido para a vontade humana que, em razão de sua limitação intrínseca, avalia as possibilidades e escolhe a que lhe parece melhor.

Ora, diante da suma perfeição da vontade divina, como supor a possibilidade de Deus anular, mudar ou violar aquilo que estabeleceu? A anulação, mudança ou violação dos decretos divinos seria, na verdade, uma prova incontestável de sua imperfeição. Ora, a vontade divina é imutável, porque é uma vontade sumamente perfeita. E se Deus agora fizesse o contrário do que já fez, isso significaria uma reconsideração e o reconhecimento de que aquilo que foi feito não foi bem feito e, portanto, fará agora melhor. Deus teria se enganado e, consequentemente, seria imperfeito.

\footnotetext{
${ }^{467}$ Sextas Respostas. AT IX, 233.
} 
Enganar-se é uma imperfeição tanto quanto ser enganador. Por isso, Descartes afirma que o que foi estabelecido por Deus não pode ser de outra maneira. Sendo assim, não se pode evocar a onipotência contra a perfeição divina, porque "a unidade, simplicidade e inseparabilidade de todas as coisas que existem em Deus é uma das principais perfeições que concebo haver nele, diz o filósofo"468.

A consideração da perfeição nos permite adquirir uma compreensão mais clara da onipotência e dos problemas provenientes de quando se pensa essa onipotência fora da perfeição. Claro que Deus tem poder absoluto para fazer qualquer coisa. Todavia, qualquer coisa que ele viesse a fazer agora, desfazendo aquilo que foi anteriormente feito, atingiria imediatamente sua perfeição. Ora, Descartes já havia elucidado os resultados problemáticos de se pensar a onipotência fora da perfeição, quando a pensou como atributo do Deus enganador e do gênio maligno. Tanto desqualifica a onipotência quanto o ser ao qual se lhe atribui, tornando-os imperfeitos. Portanto, anular, mudar ou violar a ordem estabelecida constitui uma clara evidência de que o ser sumamente perfeito enganou-se, reconsiderou, arrependeu-se, falhou. Por conseguinte, é imperfeito e, finamente, não é Deus.

\section{A incompreensibilidade divina e a negação da necessidade}

O tema da incompreensibilidade divina é introduzido na Terceira Meditação, quando da análise da ideia de Deus como ser perfeitíssimo e infinito. Enquanto tal, Deus contém infinitos atributos e cada um deles infinito. Dessa maneira, a ideia de Deus nos ensina que ele é infinitamente infinito. Tal concepção imediatamente levanta um questionamento sobre sua veracidade, em virtude da incapacidade do intelecto finito compreender os infinitos atributos divinos, sendo cada um deles infinito, como afirma Beyssade $^{469}$. O problema parece inviabilizar a veracidade da ideia que tenho de Deus e sua correspondência a ele. Mas Descartes, sem negar a incompreensibilidade, afirma:

"ainda que eu não compreenda o infinito, ou mesmo que se encontre em Deus uma infinidade de coisas que não posso compreender (comprehendere), nem talvez também tocar (attingere) pelo pensamento: pois é da natureza do infinito, que minha natureza, que é finita e limitada, não possa compreendê-lo; e é

\footnotetext{
468 Terceira Meditação. AT IX, 40.

${ }^{469}$ J.-M. Beyssade. The Idea of God and Proofs of his Existence, p. 187.
} 
suficiente que eu entenda (intelligere) bem isso, e que julgue todas as coisas que concebo claramente, e nas quais eu sei que há alguma perfeição, e talvez também uma infinidade de outras que eu ignoro, estão em Deus formal ou eminentemente, a fim de que a ideia que tenho dele seja a mais verdadeira, a mais clara e mais distinta de todas as que estão em meu espírito" ${ }^{470}$.

Do fato de que Deus seja incompreensível não resulta que a razão não possa obter um conhecimento verdadeiro, claro e distinto a seu respeito, mesmo que nele se encontrem perfeições reservadas exclusivamente a Deus, às quais ela talvez seja incapaz de tocar. A fim de dar alguma garantia à razão, é preciso recorrer à distinção cartesiana entre os modos de conhecimento, quais sejam comprehendere, concipere e intelligere. A compreensão é o ato pelo qual a razão abrange a totalidade de um objeto finito. Já na concepção, ela apreende o indefinido. Quanto à intelecção, trata-se de um ato pelo qual o intelecto atinge o infinito sem, no entanto, conhecê-lo em sua totalidade. Ora, se o ato de compreensão do intelecto finito está voltado para o objeto finito, Deus, que é infinito por natureza - a "incompreensibilidade está na razão formal do infinito"471 - e também por definição - o incompreensível é aquilo que não pode ser compreendido - não pode ser compreendido por ela. Apesar disso, Descartes lhe assegura a capacidade de ter um conhecimento claro e distinto de Deus, através da intelecção. Como ressalta Beyssade:

"entender distintamente consiste precisamente em entender (intelligere) que Deus não pode ser compreendido. Esta ideia clara e distinta, que é uma intelecção, excluindo toda a compreensão, permite uma ciência certa, um saber de Deus e de qualquer de suas perfeições" ${ }^{\text {472 }}$.

De fato, escrevendo a Mersenne, Descartes assegura que, embora a razão não seja capaz de compreender a grandeza de Deus, ela pode, em contrapartida, ter dele um conhecimento satisfatório:

"Sei que Deus é o autor de todas as coisas. Eu digo que sei, e não que o concebo nem que o compreendo; pois se pode saber que Deus é infinito e onipotente, embora nossa alma finita não possa compreendê-lo nem concebê-lo

\footnotetext{
${ }^{470}$ Terceira Meditação. AT VII, 46. AT IX, 37

${ }^{471}$ Quintas Respostas. AT VII, 368.

472 J.-M. Beyssade. Descartes au Fil de l'Ordre, p. 113.
} 
[...] pois compreender é abarcar pelo pensamento, mas para saber uma coisa, é suficiente tocá-la pelo pensamento" ${ }^{473}$.

Saber algo sem compreender é indicado por Descartes com o verbo tocar (attingere) pelo pensamento; e isso significa conhecer de modo certo, mas sem esgotar o objeto em sua totalidade:

"Pois como digo frequentemente, na questão que diz respeito a Deus, ou ao infinito, não é preciso considerar o que dele podemos compreender (porque sabemos que não deve ser compreendido por nós), mas somente o que dele podemos conceber, ou entender por qualquer razão certa" ${ }^{, 474}$.

Todavia, a questão atual sobre a incompreensibilidade divina não concerne à possibilidade efetiva do intelecto finito poder ou não ter algum conhecimento certo de Deus. A questão agora se dirige para a associação feita na Correspondência entre incompreensibilidade e onipotência divina. Extraímos daí duas passagens relevantes. A primeira afirma de Deus que:

"sua potência é incompreensivel; e geralmente podemos assegurar que Deus pode fazer tudo o que podemos compreender, mas não que ele não pode fazer o que não podemos compreender; pois seria temeridade pensar que nossa imaginação tem tanta extensão quanto sua potência"475.

Realmente, a afirmação parece acarretar dificuldades para o pensamento cartesiano. Com efeito, recorrendo à tese da simplicidade divina, na qual se assegura a identidade entre entender, querer e criar em Deus, então parece claro que se Deus pode, então está feito, e esta ordem de impossíveis é efetiva, mas inacessível à razão, sobretudo porque sua onipotência ultrapassa consideravelmente nossa imaginação.

No entanto, quando estudamos a teoria da livre criação das verdades eternas, apoiamo-nos nos autores que admoestam quanto a interpretar o verbo poder com significado temporal. Na ocasião também expusemos que Descartes admite a distinção entre a potência absoluta e a potência ordenada de Deus, ou seja, Deus pode tudo, mas

\footnotetext{
473 A Mersenne, 27 de maio de 1630. AT I, 152. Veja-se também a carta a Clerselier, AT IX, 210-211.

${ }^{474}$ Carta de agosto de 1641. AT III, 430. Há omissão do destinatário e da data em que foi escrita.

${ }^{475}$ A Mersenne, 15 de abril de 1630. AT I, 146.
} 
uma vez que instituiu as coisas que instituiu, ele se obriga a conservar as leis que ele mesmo estabeleceu. Ademais, mudar aquilo que foi estabelecido em sua perfeição atenta contra esta perfeição mesma. A afirmação feita nessa passagem ocorre na mesma carta e imediatamente após Descartes defender a imutabilidade da vontade divina, na qual se fundamenta a imutabilidade de todas as coisas que ele criou como imutáveis e eternas $^{476}$. Não nos parece então que Descartes queira afirmar uma ordem de impossíveis inacessíveis à razão, mas talvez advertir quanto à temeridade de a razão finita estabelecer aquilo que Deus pode e não pode. O filósofo reconhece explicitamente a finitude do intelecto humano para compreender as coisas que a incompreensível onipotência divina tem o poder de tornar possíveis. Do mesmo modo assegura que, mesmo tendo esse imenso poder, a onipotência quis os impossíveis efetivamente impossíveis e, portanto, "é agora verdade que é assim, e não pode ser de outra maneira" 477 .

Há a possibilidade de se extrair de Descartes argumentos para envolvê-lo em maiores dificuldades como, por exemplo, o princípio de acordo com o qual quem pode o mais pode o menos. Ora, se Deus tem poder para extrair as coisas do nada, como não pode estabelecer os impossíveis? E se não estabeleceu, faltou-lhe poder e, por conseguinte, Deus é imperfeito. Todavia, a onipotência é uma das perfeições e não se desvincula da natureza perfeitíssima de Deus. Dessa maneira, a ordem estabelecida como um todo por Deus agora - sempre Descartes ressalta o agora - expressa sua perfeição. Portanto, se Deus estabeleceu os impossíveis como impossíveis, não foi porque lhe faltou poder para torná-los possíveis, de forma alguma; nem porque julgou ser assim melhor do que outras possibilidades a ele apresentadas. Deus, em sua infinita perfeição, institui num ato único e eterno o que é para ser e o que não poderia ser de outro jeito. Não por lhe faltar poder, mas, porque esse poder é perfeito, acerta de primeira. Isso equivale a estabelecer aquilo que é para ser possível e aquilo que é para ser impossível. Evocar a onipotência agora contra ao que Deus estabeleceu é pensá-la fora da perfeição divina. Aqui, Descartes julga temeridade o ser finito delimitar o poder divino, enquanto nos Princípios, ele chama de arrogância o ato pelo qual o finito se julga partícipe dos desígnios de Deus ${ }^{478}$.

\footnotetext{
476 “Dirão que se Deus estabeleceu estas verdades, ele as poderia mudar como um rei às suas leis; o que é preciso responde que sim, se sua vontade pode mudar - mas eu as compreendo como eternas e imutáveis - e eu julgo o mesmo de Deus" (A Mersenne, 27 de maio de 1630. AT I, 145-146).

477 A Mesland, 2 de maio de 1644. AT IV, 118.

${ }^{478}$ Cf. Art. XXVIII.
} 
A segunda passagem expressa o seguinte:

"Deus é uma causa cuja potência ultrapassa os limites do entendimento humano, e a necessidade das verdades não excede nosso conhecimento, elas [as verdades] são alguma coisa de inferior e sujeita a esta potência incompreensivel" ${ }^{479}$.

O problema concernente à instituição divina de um estado de coisas contraditórias parece não ser um problema na visão de Descartes, para quem os impossíveis foram estabelecidos como impossíveis. Se fosse de outra maneira, o Deus veraz teria talvez me dotado ao menos com a capacidade de tocar (attingere) isso. Esta última passagem nos coloca novamente diante da potência incompreensível. Ela ultrapassa o entendimento humano, limitado pela necessidade. Necessidade que sempre apareceu na filosofia como alguma coisa incausada ou causada por outro gênero de causa que a causalidade eficiente (a causalidade exemplar), que parece ser o mesmo que afirmar sua incausalidade. Nesse contexto, Descartes sustenta que a necessidade é inferior e sujeita à potência incompreensível. O que, todavia, é incompreensível para o intelecto finito nesse contexto? Que a necessidade seja dependente de Deus, ou seja, que as verdades necessárias, eternas e imutáveis sejam criadas. E isto não é apenas incompreensível como é admitido como contraditório por uma tradição acostumada a limitar o poder criador às substâncias espirituais e materiais. É incompreensível que por meio do ato criador Deus instaure as verdades eternas sem lhes tirar nem diminuir a necessidade. Por isso, Gassendi teria confessado a Descartes sua dificuldade em aceitar a instituição de "alguma coisa de imutável e eterna outra que Deus". Ao que Descartes responde:

"Teríeis razão se se tratasse de uma coisa existente, ou somente se eu estabelecesse alguma coisa de tal modo imutável que sua imutabilidade mesma não dependesse de Deus. Mas penso que, porque Deus assim o quis e assim as dispôs, elas são imutáveis e eternas" ${ }^{480}$.

\footnotetext{
${ }^{479}$ A Mersenne, 6 de maio de 1630. AT I, 150.

${ }^{480}$ Quintas Respostas. AT VII, 380.
} 
A potência incompreensível, portanto, não versa sobre a instituição dos impossíveis como um estado de coisas efetivamente existentes. Pois, insistimos, a posição cartesiana admite que Deus os quis impossíveis. O poder incompreensível de Deus versa, portanto, sobre as verdades eternas, cuja incompreensibilidade reside no fato de o necessário ser necessário, conquanto criado pelo mesmo gênero de causa pelo qual Deus estabeleceu as substâncias finitas, a saber, ut efficiens \& totalis causa. Aquele que pode o mais, ou seja, que tem o poder de criar do nada, detém o poder de instituir as realidades eternas e imutáveis enquanto tais. Dessa forma, o ato criador não estabelece o possibilismo nem deflagra o contingentismo. Pelo contrário, demonstra uma absoluta unidade entre Deus e seus decretos:

"Não deveríamos distinguir aqui necessidade e indiferença nos decretos de Deus: embora ele tenha feito tudo com a mais inteira indiferença, no entanto, ele o fez ao mesmo tempo com a mais inteira necessidade. De resto, mesmo se nós nos representamos que estes decretos teriam podido ser separados de Deus, nós no-lo representamos somente ao termo de um esforço de discriminação de nossa razão; o que implica certamente entre os decretos de Deus e Deus mesmo uma distinção de razão, mas não uma distinção real, consequentemente, na coisa mesma, estes decretos não teriam podido ser separados de Deus, eles não são posteriores a ele ou distintos dele, e Deus não teria podido ser sem eles "481.

Com base no que foi analisado ao longo deste trabalho, podemos concluir não só a existência de uma teoria cartesiana da criação, mas também que tal teoria é necessária ao sistema cartesiano; pois sem a criação de todas as coisas pelo ser sumamente perfeito, Deus passa a ser contado como mais uma das instâncias inferiores rejeitadas como imperfeitas pelas Meditações. A exigência de total universalidade do ato criador torna a teoria cartesiana da criação o fundamento da teoria da livre criação das verdades eternas. Com isso, podem ser rejeitados os argumentos da marginalidade, abandono e incompatibilidade de que esta última tem sido acusada por alguns intérpretes do cartesianismo.

Quer-nos parecer que as acusações feitas por alguns estudiosos contra a teoria da livre criação das verdades resultam da uma opinião unânime nos estudos cartesianos acerca do que seja a criação em Descartes. Nesse ponto, tanto os defensores da

\footnotetext{
${ }^{481}$ L'Entretien avec Burman. AT V, 166-167.
} 
compatibilidade entre ambas as teorias como os oponentes consideram que para Descartes a noção de criação é idêntica àquela cunhada pela tradição cristã.

Descartes e a tradição cristã, de fato, asseguram que a criação é o ato pelo qual Deus produz as coisas ex nihilo. Entretanto, no pensamento cristão, o ato criador consiste em produzir uma classe de seres, os contingentes, finitos e mutáveis. Para Descartes, por outro lado, seria preciso questionar por que Deus, que é onipotente para produzir as coisas a partir de nada, só pode criar uma determinada classe de coisas e não todas, como as coisas necessárias, eternas e imutáveis. Como Deus pode o mais e não pode o menos, se essas coisas são inferiores a ele, segundo Descartes? A mesma resposta seria dada por cristãos e cartesianos, qual seja estas últimas coisas, se vinculadas à criação, não permaneceriam necessárias, eternas e imutáveis. Sendo o ato criador contingente, aquilo que dele resulta é igualmente contingente, finito e mutável. Admitir tais coisas como criadas seria um verdadeiro absurdo, uma contradição evidente, uma vez que o necessário, eterno e imutável é incompatível com o contingente, finito e mutável.

Descartes, por sua vez, guiado pela ideia de perfeição divina, concebe a criação como o ato universal pelo qual a perfeita onipotência divina produz todos os seres, os contingentes e os necessários, eternos e imutáveis. Tal é a onipotência divina que não há a menor possibilidade de que essa ação prejudique a necessidade, eternidade e imutabilidade de tais seres. Deus é o ser sumamente perfeito. Sua perfeição é reconhecida pelo alcance da onipotência. Foi a análise do alcance da onipotência que rejeitou as instâncias superiores, analisadas na Primeira Meditação.

Essa mudança na compreensão do significado de criação parece ter escapado aos estudiosos do cartesianismo, que dão a entender que o conceito cartesiano de criação permanece o mesmo da tradição cristã. De nossa parte, procuramos mostrar a diferença radical que separa Descartes da tradição e as consequências que poderiam resultar da restrição do ato criador a uma classe de seres, sendo a mais grave, o esvaziamento da perfeição divina.

Para um projeto futuro, visamos estudar a concepção cartesiana de Deus como causa de si, deixada de fora deste trabalho, por entendermos que Deus não se inclui entre os seres criados. Seguindo a mesma metodologia, pretendemos investigar a presença da ideia de Deus como causa de si na tradição filosófica anterior a Descartes, os problemas discutidos em torno desse tema, terminando com a exposição da posição cartesiana. 


\section{BIBLIOGRAFIA}

\section{Obras de Descartes:}

Oeuvres de Descartes. Ed. de C. Adam e P. Tannery. 11 vols. Paris: Vrin, 1996.

Oeuvres Philosophiques. Ed. F. Alquié. 3 vol. Paris: Garnier, 1963-1973.

Méditations Métaphysiques. Présentation par Michelle et Jean Marie Beyssade. Paris: Garnier-Flammarion, 1979.

Discours de la Méthode. Texte et Commentaire par E. Gilson. Paris: Vrin, 1925.

L'Entretien avec Burman. Edição, tradução e anotação por Jean-Marie Beyssade. Paris: PUF, 1981.

Princípios da Filosofia. Edição bilíngue. Coordenação de Guido A. de Almeida. Rio de Janeiro: Editora UFRJ, 2002.

Regras para a Orientação do Espirito. Tradução de Maria Ermantina Galvão. São Paulo: Martins Fontes, 1999.

Tutte le Lettere, 1619-1650. Testo francese, latino e olandese. Org. de Giulia Belgioioso. Milão: Bompiani, 2005.

Discurso do Método. Tradução de Enrico Corvisieri. Coleção Os Pensadores, São Paulo: Nova Cultural, 2004.

\section{Demais obras lidas ou consultadas:}

AgOStinHO. Confissões. Trad. J. Oliveira Santos e A. Ambrósio de Pina. Coleção Os Pensadores. São Paulo: Nova Cultural, 2004. . Confissões. Trad. Maria Luiza Jardim Amarante. São Paulo: Paulus, 1997.

A Cidade de Deus. Parte I (Livros I-X). Trad. Oscar Paes Lemes. Rio de Janeiro: Vozes, 2012.

. A Cidade de Deus. Parte II (Livros XI-XXII). Trad. Oscar Paes Lemes. Rio de Janeiro: Vozes, 2012.

. Contra Felix. In Obras Completas (tomo XXX). Trad. Pio de Luis. Madrid: BAC, 1986.

ALFARÁBI. Idées des Habitants de la Cité Vertueuse. Trad. R. P. Jaussen, Youssef Karam, J. Chlala. Beyrouth: Imprimerie Catholique, 1980. 
ALQUIÉ, F. La Découverte Métaphysique de l'Homme chez Descartes. Paris: PUF, 1950.

ANGELINI, Elisa. Le Idee e le Cose. La Teoria della Percezione di Descartes. Pisa: ETS, 2007.

ARIEW, R. Descartes and the Last Scholastics. New York: Cornell University Press, 1999.

ARISTÓTELES. Metafísica. Trad. Leonel Vallandro. Porto Alegre: Editora Globo, 1969.

AUBENQUE, P.; BERNHARDT, J.; CHATÊLET, F. A Filosofia Paga: do séc. IV a. C. ao séc. III d. C. Coleção História da Filosofia, n. 1. Trad. Maria Helena Couto Lopes e Nina Constante Pereira. Lisboa: Publicações Dom Quixote, 1983

AVICENNA LATINUS. Liber de Philosophia Prima. Ed. S. van Riet. Louvain: Peeters, 1977.

BAIÃO, G. Teorias Cosmológicas no Estoicismo Antigo. In Revista Dissertatio, n. 31. Pelotas: 2010.

BARRA, E. S. O. A Metafísica Cartesiana das Causas do Movimento: Mecanicismo e Ação Divina. In Scietiae Studia, v. 1, n.3. São Paulo: 2003.

BECK, L. J. The Metaphysics of Descartes: A Study of the Meditations. Oxford: Clarendon Press, 1965.

BEYSSADE, J-M. Descartes au Fil de l'Ordre. Paris: Puf, 2001. La Philosophie Première de Descartes. Paris: Flammarion, 1979.

A Teoria Cartesiana da Substância. Equivocidade ou Analogia? Tradução de Lia Levy. In Analytica, v. 2, n. 2. Rio de Janeiro: 1997. . The Idea of God and Proofs of his Existence. In The Cambridge Companion to Descartes. Ed. by Cottingham. Cambridge: Cambridge University Press, 1992.

BLOCH, Oliver René. La Philosophie de Gassendi: Nominalisme, Matérialisme, et Métaphysique. Paris: Springer, 1971.

BOEHNER, P. GILSON. E. História da Filosofia Cristã: desde as origens até Nicolau de Cusa. Petrópolis: Vozes, 2003.

BOUTROUX, E. De Veritatibus Aeternis apud Cartesium (1874). Trad. Francesa de M. Canguilhem. Paris: Félix Alcan, 1927. 
BOUVERESSE, J. La Théorie du Possible chez Descartes. In Eternal Truths and Cartesian Circle. Ed. By Willis Doney. New York \& London: Garland Publishing, Inc., 1987.

BRÉHIER, E. La Création des Verités Eternelles dans le Système de Descartes. In Revue Philosophique de la France et de l'Étranger, Vol. CXIII. Mai-August, 1937.

BRIESKORN, N. Francisco Suárez - a respeito da Disputatio Metaphysica XXXIII. In Veritas, vol. 54, n. 3. Porto Alegre: 2009.

BURNET, J. Early Greek Philosophy. New York: Penguin Books, 1987.

CARRAUD, V. Causa sive Ratio. La Raison de la Cause, de Suárez a Leibniz. Paris: PUF, 2002.

CHAUI, M. A Nervura do Real. São Paulo: Companhia das Letras, 1999. . Introdução à História da Filosofia: Dos Pré-socráticos a Aristóteles. v. I, $2^{\text {a }}$ Ed. São Paulo. Companhia das Letras, 2011.

Introdução à História da Filosofia: As Escolas Helenísticas. v. II. São Paulo. Companhia das Letras, 2010.

CLÉMENT D'ALEXANDRIE. Le Protreptique. Trad. Claude Mondésert. Paris: Les Éditions du CERF, 2004.

CLEVE, J. Van. Descartes and the Destruction of the Eternal Truths. In Ratio (New Series), vol. 7, n. 1, june. Reading, 1994.

CORNFORD, F. M. Principium Sapientiae. Trad. M. Manuela R. dos Santos. Lisboa: Fundação Calouste Gulbenkian, 1981. Plato's Cosmology. London: Routledge \& Kegan Paul, 1966.

COTTINGHAM, J. Dicionário Descartes. Trad. Helena Martins. Rio de Janeiro: JZE, 1995.

COURTENAY, W. J. The Dialectic of Omnipotence in Medieval Philosophy. Ed. por Tamar Rudavsky. Dordrecht: Reidel, 1985.

Capacity and Volition: A History of the Distinction of Absolute and Ordained Power. Bergamo: Pierluigi Lubrina, 1990.

COURTINE. J.-F. Suarez et le Système de la Metaphysique. Paris: PUF, 1990.

CROIX, R. La. Descartes on God's Ability to do the Logically Impossible. In René Descartes Critical Assessments. Ed. Georges J. D. Moyal. London: Routledge, 1991. 
CRONIN, T. J. Eternal Truths in the Thought of Descartes and his Adversary. In Journal of the History of Ideas, vol. 21, 1960.

. Eternal Truths in the Thought of Suárez and Descartes. Modern Schoolman, vol. 39, 1961.

CURLEY. E. M. Descartes on the Creation of the Eternal Truths. In the Philosophical Review, vol. XCIII, n. 4. October. New York: 1984.

De volta ao Argumento Ontológico. Trad. Ethel M. Rocha. In Analytica, v. 2, n. 2. Rio de Janeiro, 1997.

EPICURO. Antologia de Textos de Epicuro. Coleção Os Pensadores. São Paulo: Abril Cultural, 1973.

ERLER, M. \& GRAESER, A. (orgs.) O Medioplatonismo: Filosofia e Tradição. In Filósofos da Antiguidade 2: do Helenismo à Antiguidade Tardia. São Leopoldo: Unisinos, 2003.

ESPINOSA. Ética. São Paulo: Nova Cultural, 1991.

ROCHA, E. M. O Conceito de Realidade Objetiva na Terceira Meditação de Descartes. In Analytica, v. 2, n. 2. Rio de Janeiro: 1997.

FERRIER, R. Aperçus Nouveaux sur la Cosmologie Cartésienne. In Revue de Synthèse, tome XXII, Janvier-Juan. Paris: A. Michel, 1948.

FICHANT, M. Science et Métaphysique dans Descartes et Leibniz. Paris: PUF, 1998. FILHO, R. L. Idealismo ou Realismo na Filosofia Primeira de Descartes. Análise da Crítica de Kant a Descartes no IV Paralogismo da CRP[A]. In Analytica, v. 2, n. 2. Rio de Janeiro, 1997.

FORLIN, E. A Teoria Cartesiana da Verdade. São Paulo: Humanitas/Unijuí, 2005. - O Ser da Ciência e a Ciência do Ser na Filosofia de Descartes. In Cadernos de História e Filosofia da Ciência, série 3, v. 16, n.1, jan-jun. Campinas, 2006.

FRANKFURT, H. Demons, Dreamers and Madmen - The Defense of Reason in Descartes’ Meditations. New York: The Bobbs-Merrill Company, Inc., 1970. - Descartes on the Creation of the Eternal Truths. In The Philosophical Review, vol. LXXXVI, n 1. January. New York: 1977.

GARIN, P. Thèses Cartésiennes et Thèses Thomistes. Paris: Desclée de Brouwer, 1931.

GASPARRI, Giuliano. Le Grand Paradoxe de M. Descartes. La Teoria Cartesiana delle Verità Eterne nell'Europa del XVII Secolo. Florença: Olschki, 2008. 
GILSON, E. A Filosofia na Idade Média. Trad. Eduardo Brandão. São Paulo: Martins Fontes, 1995.

. Index Scolastico-Cartésien. Paris: Vrin, 1979.

- Études sur la Rôle de la Pensée Médiévale dans la Formation du Système Cartésien. Paris: Vrin, 1951.

. La Liberté chez Descartes et la Théologie. Paris: Librairie Félix Alcan, 1913.

Études sur l'Histoire de la Formation du Système Cartésien. Paris: Vrin, 1930.

. La Philosophie de Saint Bonaventure. Paris: Vrin, 1978.

GLEIZER, M. A. Considerações acerca da Doutrina da Livre Criação das

Verdades Eternas. In Conhecimento, Verdade e Ação. Ensaios em homenagem a Guido A. de Almeida e Raul Landim Filho. Org. de E. da R.

Marques, E. M. Rocha, L. Levy, L. C. Pereira, M. A. Gleizer, U. Pinheiro. São Paulo: Loyola, 1999.

GOUHIER, H. Descartes. Essais sur le Discours de la Méthode, la Métaphysique et la Morale. Paris: Vrin, 1973. . La Pensée Métaphysique de Descartes. Paris: Vrin, 1962. . Cartésianisme et Augustinisme au XVII siècle. Paris: Vrin, 1978.

GUEROULT, M. Descartes selon l'Ordre des Raisons (vols. 1 e 2). Paris: Aubier éditions Montaigne, 1953.

Nouvelles Réflexions sur la Preuve Ontologique de Descartes. Paris: Vrin, 1955.

GUERRERO, M. K. O Processo de Abstração e o Fundamento Real dos Universais em Tomás de Aquino. In Revista Índice, vol. 1, n. 1. Rio de Janeiro: 2009

GRIMALDI, N. L'Expérience de la Pensée dans la Philosophie de Descartes. Paris: Vrin, 1978.

GONÇALVES, J. C. Homem e Mundo em São Boaventura. Portalegre: Braga, 1970.

HELLER, A. Estoicismo e Epicurismo. In O Homem do Renascimento. Lisboa: Presença, 1982.

HERMAS. The Shepherd. Trad. J. B. Lightfoot. Disponível em http://www.earlychristianwritings.com/text/shepherd-lightfoot.html. Acessado em 18/08/2009.

HESÍODO. Teogonia. Trad. Jaa Torrano. São Paulo: Iluminuras, 2003. 
HOMERO. Ilíada, v. I. Trad. Haroldo de Campos. São Paulo: Mandarim, 2002.

JAEGER, W.W. Early Christianity and Greek Paideia. Cambridge: Harvard University Press, 1961.

JOURNEL, M. J. R. Enchiridion Patristicum. 20a ed. Barcinone, Friburgi Brisg., Romae: Herder, 1958.

JOY, Lynn Sumida. Gassendi the atomist. Nova Iorque: Cambridge University Press, 2002.

JUSTIN. Apologie pour les Chrétiens. Trad. Charles Mounier. Paris: Les Éditions du CERF, 2006.

KAHN, C. H. Anaximander and the Origins of Greek Cosmology. New York: Columbia University Press, 1960.

KANT, I. Crítica da Razão Pura. Trad. Valério Rohden. Coleção Os Pensadores. São Paulo: Abril Cultural, 1974.

KENNY, A. Descartes, a Study of his Philosophy. New York: Random House, 1968.

KIRK, G. S. RAVEN, J. E. SCHOFIELD, M. Os Filósofos Pré-Socráticos. Trad. C. Alberto L. Fonseca. Lisboa: Fundação Kalouste Gulbenkian, 1994.

KOJÈVE, A. Essai d’une Histoire Raisonnée de la Philosophie Païenne (vols 1, 2 e 3). Paris: Gallimard, 1997.

KOYRÉ, A. Essai sur l'Idée de Dieu et les Preuves de son Existence chez Descartes. Paris: Ed. Ernest Leroux, 1922. Études Galiléennes. Paris: Hermann, 1939.

LAGRÉE, J. Le Néostö̈cisme. Paris: Vrin, 2010.

LAPORTE, J. Le Rationalisme de Descartes. Paris: PUF, 1945.

LEFF, Gordon. William of Ockham: The Metamorphosis of Scholastic Discourse. Manchester: Manchester University Press, 1975.

MARION, J.-L. Sur l'Ontologie Grise de Descartes. Science Cartésienne et Savoir Aristotélicien dans le Regulae. Paris: Vrin, 1975.

. Sur la Théologie Blanche de Descartes. Analogie, Création desVerités Éternelles et Fondement. Paris: PUF, 1981.

Questions Cartésiennes. 2 vol. Paris: PUF, 1991.

MONDIN, B. Quem é Deus? Elementos de Teologia Filosófica. São Paulo: Paulus, 1997. 
MONTICELli, P. A Relação ao Objeto: um Estudo a partir do Pensamento de Francisco Suárez. 2010. 100 f. Tese (Doutorado em Filosofia). Pontifícia Universidade Católica de São Paulo. São Paulo, 2010.

NOVAK, J. A Sense of Eidos. In EIDOS: Canadian Graduate Journal of Philosophy, v. XIX, n. 2. January. Waterloo: 2005.

OAKLEY, F. Omnipotence, Covenant and Order: An Excursion in the History of Ideas from Abelard to Leibniz. New York: Cornell University Press, 1984.

OCKHAM, W. Philosophical Writins. Edição e tradução de Philotheus Boehner. Edinburg: Nelson, 1957.

- Summa Totius Logicae. In Ockham's Theory of Terms. Part I of the Summa Logicae. Edição e tradução de Michael J. Loux. Notre Dame, Ind: University of Notre Dame Press, 1974.

OLIVEIRA, C. E. P. Descartes: A Livre Criação das Verdades Eternas, 2008, $127 \mathrm{f}$. Dissertação (Mestrado) - Faculdade de Filosofia, Letras e Ciências Humanas, Universidade de São Paulo. São Paulo, 2008. Disponível em http://www.fflch.usp.br/df/site/posgraduacao/2008_mes/2008.Carlos_Oliveira.mes.df acessado em 10/05/2013.

OLIVO, G. Descartes et l'Essence de la Verité. Paris: PUF, 2005.

ONG-VAN-CUNG, K. S. Descartes et l'Ambivalence de la Création. Paris: Vrin, 2000

ORIGÈNE. Traité des Principes I. Trad. H. Crouzel et M. Simonetti. Paris: Les Éditions du CERF, 1978.

ORTIZ, A. V. Las tres Hipóstasis dentro del Pensamiento de Plotino: el camino de la Materia. In A Parte Rei Revista de Filosofía, n. 63, mayo. España: 2009.

OSLER, M. J. Divine Will and the Mechanical Philosophy. New York: Cambridge University Press, 1998.

PEÑA, R. L. de la. Teologia da Criação. Tradução de José A. Ceschin. São Paulo: Loyola, 1989.

PLATÃO. Timeu. Trad. Maria José Figueiredo. Lisboa: Instituto Piaget, 2003.

PLOTINO. Tratado das Enéadas. Trad. Américo Sommerman. São Paulo: Polar, 2002.

PRETE, A. Del. Universo Infinito e Pluralità dei Mondi: Teorie Cosmologiche in Età Moderna. Napoli: La Città del Sole, 1998.

RAPOSO. E. R. F. G. Francisco Suárez. Último Medieval, Primeiro Moderno: A Ideia Exemplar. In Cauriensia, vol. V. Porto: 2010. 
REALE, G. \& ANTISERI, D. História da Filosofia I: Antiguidade e Idade Média. São Paulo: Paulus, 1990.

RENAULT, L. Descartes et les Théories Médiévales de l'Abstraction. Quelque points de Repères. In Descartes et Moyen Age. Ed. Por J. Briard e R. Rashed. Paris: Vrin, 1997.

RIOS, A. R. Ensaios sobre Suárez e Descartes. Rio de Janeiro: Book Link, 2005.

RODIS-LEWIS, G. L'Oeuvre de Descartes. 2 vol. Paris: Vrin, 1971. Idées et Vérités Éternelles chez Descartes et ses Successeurs. Paris: Vrin, 1985.

SANTIAGO, H. S. Descartes, Espinosa e a Necessidade das Verdades Eternas. In Cadernos de História e Filosofia da Ciência, série 3, v. 12, $n^{\circ}$ 1-2, jan-dez, Campinas, 2002. Espinosa e o Cartesianismo. O Estabelecimento da Ordem nos Princípios da Filosofia Cartesiana. São Paulo: Associação Editorial Humanitas, 2004.

SCHOULS, P. A. Descartes and the Possibility of Science. New York: Cornell University Press, 2000.

SILVA, F. Leopoldo e. Tempo: Experiência e Pensamento. In Revista USP, n. 81, março/maio. São Paulo, 2009.

STEENBERGHEN, F. Van. Dieu Caché. Paris: Ed. Béatrice-Nauwelarts, 1961.

STORCK, A. Eternidade, Possibilidade e Emanação. In Analytica, vol. 7, n. 1. Rio de Janeiro: 2003.

STROUMSA, GUY G. Barbarian Philosophy: The Religious Revolution of Early Christianity. Tübingen: Mohr Siebeck, 1999.

SUÁREZ, F. Disputationes Metaphysicae. Opera Omnia (vols. 25 e 26). Paris: Ed. M André e C. Berton, 1856-1878. . La Distiction de l'Étant Fini et de son Être. Dispute Métaphysique XXXI.Texte integral presenté, traduit e annoté par Jean-Paul Coujou. Paris: Vrin, 1999.

TOMÁS DE AQUINO. Opera Omnia. Disponível em http://www.corpusthomisticum.org/iopera.html. Acessado em 20/02/2012. Suma Teológica. Tradução coordenada por Carlos Josaphat de Oliveira. São Paulo: Loyola, 2001. 
$O$ Ente e a Essência. Tradução de Luiz João

Baraúna. Coleção Os Pensadores: Nova Cultural, 2004.

Suma contra os Gentios I. Tradução de D. Odilão

Moura e D. Ludgero Jaspers. Porto Alegre/Caxias do Sul: EST/Sulina/UCS, 1990.

Questões Discutidas sobre a verdade (Questão I).

Tradução de Luiz João Baraúna. Coleção Os Pensadores. São Paulo: Nova Cultural, 2004.

TACIANO. Discurso aos Gregos. Tradução de Ivo Storniolo e Euclides M.

Balancin. In Patrística: Padres Apostólicos, vol. II. São Paulo: Paulus, 1997.

VERGES, S. Dios y el Hombre: la Creación. Madrid: BAC, 1980.

VV. AA. Essays on the Philosophy and Science of René Descartes. Editado por Stephen Voss. New York: Oxford University Press, 1993.

VV. AA. Descartes: A Collection of Critical Essays. Editado por Willis Doney. London. University of Notre Dame Press, 1967.

VV. AA. The Cambridge History of Seventeenth-Century Philosophy. Org. Daniel Garber e Michael Ayers. 2 vol. Cambridge: Cambridge University Press, 1998.

VV. AA. La Puissance et son Ombre. De Pierre Lombard à Luther. Textes traduits et présentés par Olivier Boulnois (Dir.), Jean-François Genest, Elizabeth Karger, Alain de Libera, Cyrille Michon, Marc Ozilou, Jean Luc Solère. Paris: Aubier, 1994.

WILSON, M. D. Descartes. London: Routledge, 1978. 